\title{
MERCADOS FUTUROS: CUSTOS DE TRANSAÇÃO ASSOCIADOS À TRIBUTAÇÃO, MARGEM, AJUSTES E ESTRUTURA FINANCEIRA
}

\author{
Elisson Augusto Pires de Andrade
}

\begin{abstract}
Dissertação apresentada à Escola Superior de Agricultura "Luiz de Queiroz”, Universidade de São Paulo, para obtenção do título de Mestre em Ciências, Área de Concentração: Economia Aplicada.
\end{abstract}

P I R A C I C A B A

Estado de São Paulo - Brasil

Janeiro de 2004 


\title{
MERCADOS FUTUROS: CUSTOS DE TRANSAÇÃO ASSOCIADOS À TRIBUTAÇÃO, MARGEM, AJUSTES E ESTRUTURA FINANCEIRA
}

\author{
Elisson Augusto Pires de Andrade \\ Engenheiro Agrônomo
}

Orientador: Prof. Dr. PEDRO VALENTIM MARQUES

\begin{abstract}
Dissertação apresentada à Escola Superior de Agricultura "Luiz de Queiroz", Universidade de São Paulo, para obtenção do título de Mestre em Ciências, Área de Concentração: Economia Aplicada.
\end{abstract}

P I R A C I C A B A

Estado de São Paulo - Brasil

Janeiro de 2004 
Dados Internacionais de Catalogação na Publicação (CIP) DIVISÃO DE BIBLIOTECA E DOCUMENTAÇÃO - ESALQ/ USP

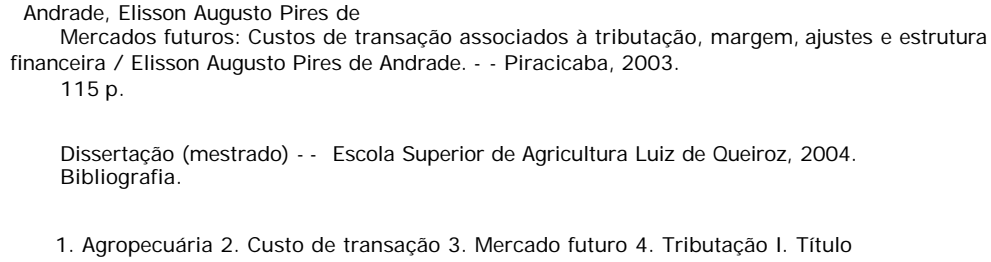

1. Agropecuária 2. Custo de transação 3. Mercado futuro 4. Tributação I. Título

CDD 332.645

"Permitida a cópia total ou parcial deste documento, desde que citada a fonte - $\mathrm{O}$ autor" 
“OEV se realiza na relação com o TU; é tornando $\mathcal{E V}$ que digo TU. Toda vida atual é encontro."

"Sem dúvida, alguém que se contenta com o mundo das coisas, em experienciálas e utilizá-las, erigiu um anexo e uma super-estrutura de idéias nos quais encontra um refúgio e uma tranqüilidade diante da tentação do nada (...). Mas a humanidade reduzida a um ISSO, tal como se pode imaginar, postular ou proclamar, nada tem em comum com uma humanidade verdadeiramente encarnada à qual um homem diz verdadeiramente TU."

"As idéias tão pouco reinam acima de nossas cabę̧as como habitam em nossas cabeças; elas caminham entre nós e se dirigem para nós."

"Os sentimentos, nós os possuímos, o amor acontece. Os sentimentos habitam no homem, mas o homem habita em seu amor. Isto não é simples metáfora, mas a realidade. O amor não está ligado ao $\mathcal{E U}$ de tal modo que o TU fosse considerado um conteúdo, um objeto: ele se realiza entre o $E V$ e o $T$ U.

"Amor é responsabilidade de um $\mathcal{E V}$ para com um TU: nisto consiste a igualdade daqueles que amam."

Trechos da obra de Martin Buber EU e TU (2003) - 6a'Ed. 


\section{OFEREÇO:}

A Deus, que me iluminou e me deu saúde

durante todos os anos de graduação e mestrado

$E$ a todos os TUS que fizeram do meu EU um homem feliz

Em especial aos magníficos

Nise, Laine, Lelê e Tatinha

DEDICO:

Às duas pessoas mais importantes da minha vida: meus pais.

João Antonio e Maria Denise.

É da relação com vocês que surge o meu melhor EU. 


\section{AGRADECIMENTOS}

Queria agradecer à instituição mais importante a qual pertenço: minha família. João, Denise, Nise, Laine, Lelê, tios, primos, avós, todos que me acompanharam durante boa parte de minha vida. Aos meus cunhados: Léo, Barata e Alessandra. Às minhas sobrinhas Lalazinha e Laura, e aos familiares que, certamente, ainda hão de vir.

Expresso aqui minha gratidão à gloriosa ESALQ-USP por me acolher durante oito anos - graduação e mestrado - em que aprendi muito e me tornei um ser humano muito mais capaz. E meus sentimentos estendem-se a todos os funcionários do departamento de Economia, Sociologia e Administração: Pedro, Cris, Helena, Márcia,

Álvaro, Ligiana, e principalmente ao maior exemplo de amor ao trabalho e dedicação aos alunos: minha amiga Maielli. Obrigado a todos os professores do departamento, Márcia Azanha, Alexandre Mendonça, Joaquim Bento, José Vicente Caixeta, Zilda Paes, Geraldo Barros, e tantos outros que participaram da minha acumulação de conhecimentos. Meus agradecimentos também ao $\mathrm{CNPq}$, pela bolsa de fomento oferecida durante dois anos de mestrado e que possibilitou uma vida acadêmica mais estável.

Ao professor Pedro Marques, meu mestre, orientador, conselheiro e amigo, meus sinceros agradecimentos por me acolher de braços abertos no departamento de economia durante tantos anos e me motivar a seguir sempre os melhores caminhos. Impossível esquecer e deixar de grafar nestas linhas minha sincera gratidão para com o professor Adriano Azevedo-Filho: a pessoa mais genial que passou pela minha vida acadêmica e que me deu o prazer de aprender, a cada conversa, muito mais que em qualquer outro lugar. Professor Adriano, obrigado pela paciência que sempre teve comigo e essa dissertação também é sua. 
Queria deixar o meu abraço aos amigos que fiz na graduação, e que tanto me deram o prazer de aqui estudar. Uma dedicatória especial vai ao irmão que conquistei, Fábio Maya: o aluno mais inteligente e íntegro que conheci e que tive a oportunidade de conviver por anos e anos. Obrigado por me aturar e por me ajudar a entender que trabalho e seriedade são essenciais para a formação de um bom caráter, além das noitadas... não é candango?!?!?!?!?

Também deixo expressa minha de eterna gratidão a todos que conviveram comigo durante meu mestrado, fazendo da minha vida algo prazeroso e escutando todas as minhas histórias durante os famosos cafezinhos. Agradeço a todos, sem exceção. Mas deixarei relatado alguns que conviveram comigo por mais tempo: Silvio, Nicolella, Lucílio, César, Roberto, Jiló, André Truta, Lanterna, Spolador, Paulão, Julcemar, Ronaldão e tantos outros.

Não posso esquecer de toda a galera de Limeira. Meus amigos e inimigos, devo a vocês muito do que sou. Minha homenagem a toda galera que um dia foi do glorioso Mukiranas do Brás: Arilson, Serginho, Marcão, Nilzinho, Davison, Mirellinha, Milaré, Má, Ti, Gica, Rossano, Geleca, Rico, Marcel, Bertola... impossível falar em todos. Meu muito obrigado a todos vocês. Aos meus amigos do glorioso Bar do Laurito, meus agradecimentos pelos momentos de descontração proporcionados durante anos e anos de convivência: Maurício, Mauro, Maninho, Danilo, Alex, Leandro, Rafael, Didi, e todos que lá compartilham momentos felizes.

E, por último, mas não menos (ou até mais) importante que muitos dos citados, queria agradecer de coração ao apoio e paciência de Tatiana Adam, minha companheira e amiga durante grande parte do mestrado. É muito bom ter você ao meu lado e espero que nos permitamos continuar com esse sentimento mútuo por muito tempo. 


\section{SUMÁRIO}

Página

LISTA DE FIGURAS.............................................................................. ix

LISTA DE QUADROS..........................................................................

LISTA DE TABELAS...............................................................................

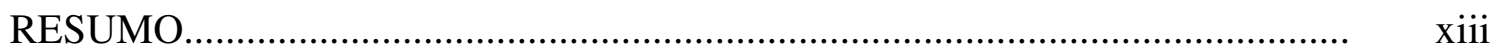

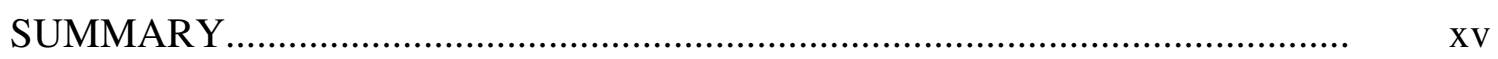

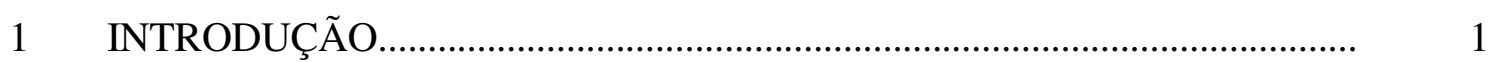

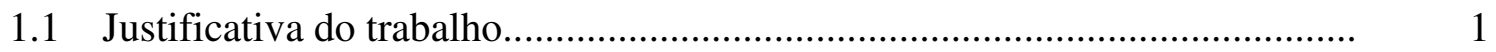

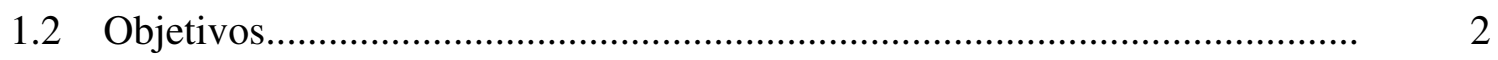

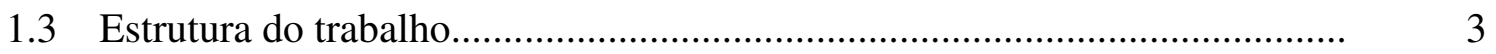

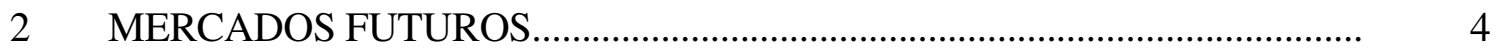

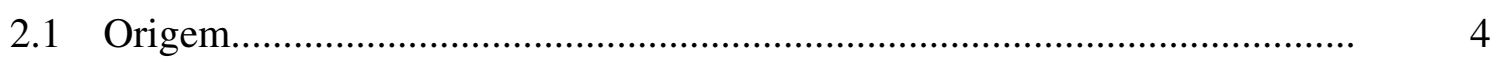

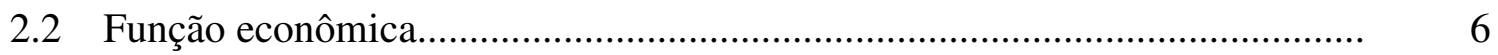

2.3 Mercados Futuros Agropecuários.......................................................... 10

2.4 Caracterização dos Agentes do Mercado Agropecuário................................ 13

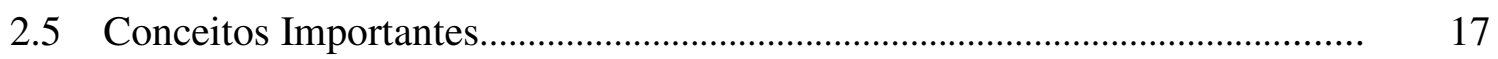

3 CUSTOS DE TRANSAÇÃO EM MERCADOS FUTUROS........................... 22

3.1 Interação entre Risco e Custo de Transação........................................................... 22

3.2 Importância econômica dos custos de transação................................................. 25

3.3 Estudos sobre custos de transação aplicados aos mercados futuros.................. 27

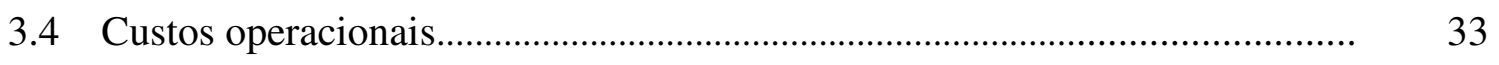

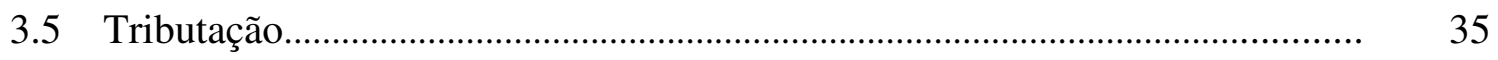

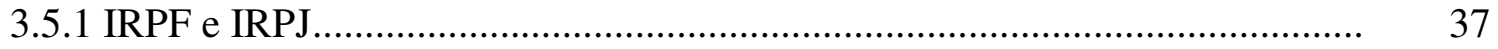

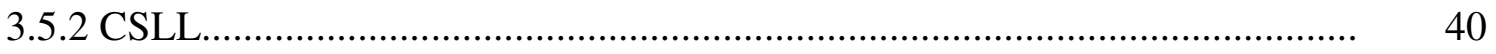




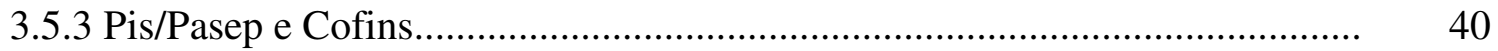

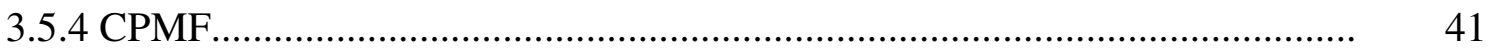

3.6 Modelagem da influência dos custos de transação em tomadas de decisão.... 42

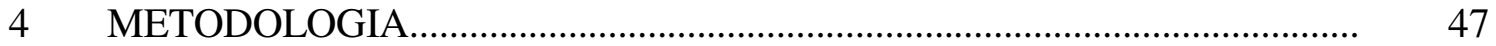

4.1 Obtenção das informações sobre custos de transação....................................... 47

4.2 Metodologia para mensuração dos custos de transação................................. 48

4.2.1 Definição dos custos................................................................................ 49

4.2.2 Formalização dos custos de transação....................................................... 53

4.2.3 Cálculo com base em séries históricas observadas (método 1)..................... 58

4.2.4 Simulação Monte Carlo: modelos ARIMA-GARCH (método 2).................. 60

4.2.5 Simulação Monte Carlo: modelo simplificado (método 3)........................... 65

5 PROPOSTAS DE SISTAMATIZAÇÃO: RESULTADOS.............................. 70

5.1 Sistematização dos custos de transação em mercados futuros............................ 70

5.1.1 Custos de aprendizado e capacitação....................................................... 72

5.1.2 Custos associados a taxas de bolsa e corretoras........................................ 73

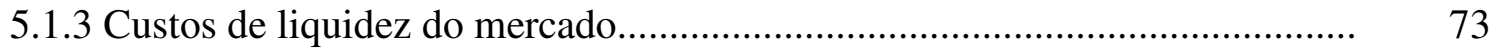

5.1.4 Custos de administração da operação......................................................... 73

5.1.5 Custos de margem e ajustes................................................................. 75

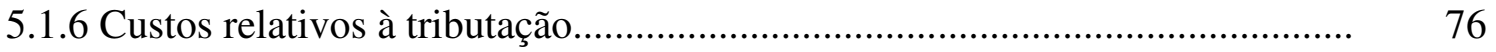

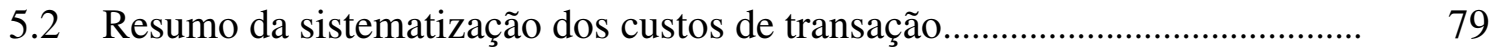

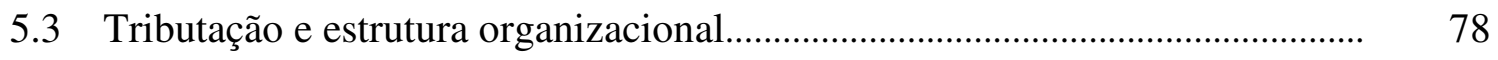

6 MENSURAÇÃO DOS CUSTOS DE TRANSAÇÃO: RESULTADOS........ 82

6.1 Resultados do Método 1..................................................................................... 82

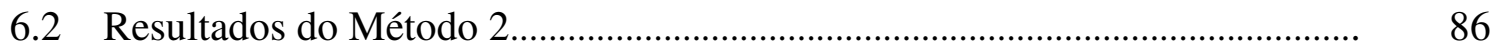

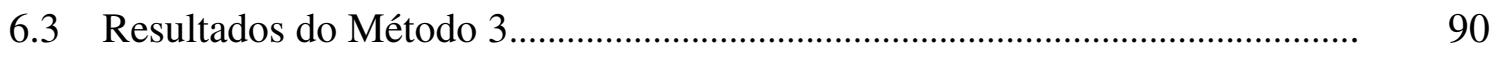

6.4 Formas de diminuição dos custos transacionais..................................................... 95

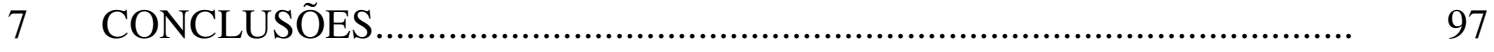

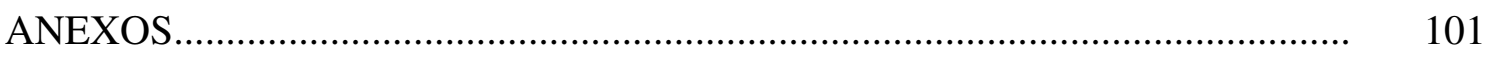

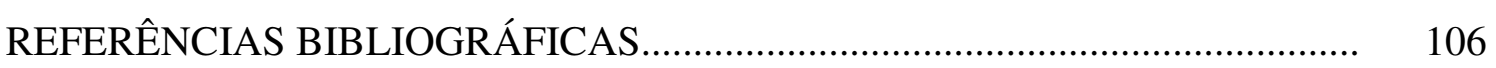




\section{LISTA DE FIGURAS}

Página

1 Custos totais médios como \% do valor inicial do contrato, estimados a partir do modelo simplificado, para agentes tipo 1 .................................................... 92

2 Custos totais médios como \% do valor inicial do contrato, estimados a partir do modelo simplificado, para agentes tipo 2 ...................................................... 93

3 Estimativas da distribuição do custo total, como \% do valor inicial do contrato, a partir do modelo simplificado, para agente tipo 2 e volatilidade anualizada de 0,25, em função do número de dias. 


\section{LISTA DE QUADROS}

Página

1 Potenciais custos de transação em mercados futuros ........................................ 79

2 Resumo dos tributos incidentes em operações em mercados futuros .................... 81 


\section{LISTA DE TABELAS}

Página

1 Volume de contratos agrícolas negociados na CBOT e suas respectivas produções agrícolas mundiais, no ano de 2001

2 Evolução do volume de contratos negociados na BM\&F (19962002)

3 Valor de margem de garantia, por contrato negociado, dos derivativos agropecuários negociados na BM\&F (25/08/2003).................................. 20

4 Custos operacionais das commodities agrícolas na BM\&F............................ 34

5 Tabela progressiva para cálculo anual do imposto de renda de pessoa física para o exercício de 2003, ano-calendário de 2002 ........................................ 38

6 Custos de transação estimados em trajetórias de preços observadas no contrato

7 Custos de transação estimados em trajetórias de preços observadas no contrato de milho (BM\&F) para agentes tipo 2 (descapitalizados)

8 Custos de transação estimados em trajetórias de preços observadas no contrato de milho $(\mathrm{BM} \& \mathrm{~F})$ para agentes tipo 1

9 Custos de transação estimados, em trajetórias de preços observadas no contrato de milho $(\mathrm{BM} \& \mathrm{~F})$ para agentes tipo 2 ......................................... 84

10 Modelos selecionados para representação de cada série................................. 87

11 Custos de transação médios, estimados em 10.000 trajetórias de preços, simuladas a partir de modelos selecionados para agentes tipo 1 ..................... $\quad 88$

12 Custos de transação médios, estimados em 10.000 trajetórias de preços, simuladas a partir de modelos selecionados para agentes tipo 2 
13 Matriz de correlação amostral entre os componentes do custo do modelo

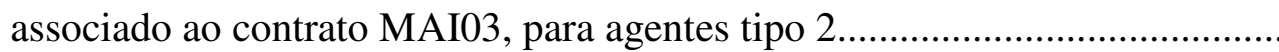

14 Matriz de correlação amostral entre os componentes do custo do modelo

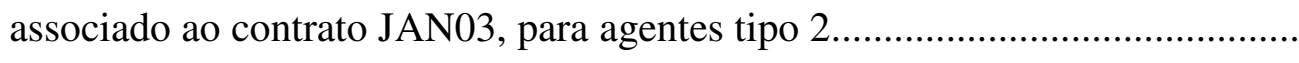

15 Volatilidade estimada através da trajetória real dos preços futuros do milho na $\mathrm{BM} \& \mathrm{~F}$

16 Custos de transação estimados em 10.000 trajetórias de preços simuladas a partir do modelo simplificado, para agentes tipo 2 (descapitalizados).............. 


\title{
MERCADOS FUTUROS: CUSTOS DE TRANSAÇÃO ASSOCIADOS À TRIBUTAÇÃO, MARGEM, AJUSTES, TAXAS E ESTRUTURA FINANCEIRA DO AGENTE
}

\author{
Autor: ELISSON AUGUSTO PIRES DE ANDRADE \\ Orientador: Prof. Dr. PEDRO VALENTIM MARQUES
}

\section{RESUMO}

Esta pesquisa teve como objetivo estudar a importância dos custos de transação nas operações em mercados futuros no Brasil. Para isso, foi proposta, primeiramente, uma sistematização dos custos de transação, dividindo-os em sete categorias, expostas a seguir: 1) aprendizado e capacitação; 2) taxas da bolsa e corretoras; 3) liquidez do mercado; 4) administração da operação; 5) margem de garantia; 6) necessidade de pagamento de ajustes diários; 7) tributação. O custo relativo à tributação, em particular, face à percepção de que não havia uma clareza quanto às suas características, foi também sistematizado de maneira que pudesse ser compreendido mais claramente. Pessoas físicas e pessoas jurídicas são tributadas diferentemente nas operações em bolsa de futuros, sendo que há diferença também dentro da própria classificação de pessoa jurídica - tributadas com base no lucro real, presumido ou arbitrado. Feita essa caracterização, foram estudados de maneira mais acurada alguns custos em particular, para o caso de pessoa física e com aplicação aos mercados futuros brasileiro da BM\&F. Os custos analisados foram: tributação (IRPF e CPMF), taxas da bolsa e corretora, 
margem de garantia e ajustes diários. O que se propôs foi a aplicação de três métodos distintos e complementares, que possibilitassem sua mensuração. $\mathrm{O}$ primeiro método baseou-se em séries históricas de preços; o segundo utilizou-se de técnicas de simulação Monte Carlo, através de modelos ARIMA-GARCH; e o terceiro método também usou a técnica de simulação, porém, através de um modelo teórico mais simples. Os resultados obtidos demonstraram que em certas situações os custos podem ser muito elevados, e que pesquisas relativas aos mercados futuros que admitem ausência de custo, ou que utilizem apenas as taxas cobradas pela bolsa e corretoras, podem estar incorrendo em erros consideráveis. Para evidenciar essa argumentação, na presente pesquisa chegou-se, por exemplo, a valores de custos de transação médios que variaram de 2 a 6,5\% do valor inicial do contrato. Os métodos utilizados permitiram analisar a influência de diversos fatores na magnitude dos custos: tempo de operação, grau de capitalização do agente, volatilidade e tipo de operação (compra ou venda de contratos). O que se concluiu foi o alto grau de dependência dos custos de transação analisados com relação às possíveis trajetórias de preço, durante a vida do contrato. Ao considerar que no início do contrato a real trajetória de preços que será verificada é desconhecida (incerta), nota-se a existência de um risco de custo, que pode ser assimétrico entre as partes compradas e vendidas. O risco de custo acaba diminuindo o benefício de administração de risco oferecido pelos mercados futuros, tendo efeito semelhante ao risco de base. Porém, o risco de custo independe de operações no mercado físico, algo que não acontece em se tratando da variável base. 


\title{
FUTURES MARKETS: TRANSACTION COSTS ASSOCIATED WITH TRIBUTES, MARGIN, CASH FLOWS, OPERATIOPNAL TAXES AND FINANTIAL STRUCTURE
}

\author{
Author: ELISSON AUGUSTO PIRES DE ANDRADE \\ Adviser: Prof. Dr. PEDRO VALENTIM MARQUES
}

\section{SUMMARY}

This research had the objective to study the importance of transaction costs in the context of Brazilian futures markets. To do that, it was proposed, primarily, a transaction cost systematization, dividing them into seven categories as follows: 1) learning and qualification; 2) exchange and brokers fees; 3) liquidity of market; 4) operation management; 5) margin; 5) cash settlement; 7) tributes. The tributes cost, that was observed as being not clearly understandable by the agents of the markets, was also systematized in a manner to be better comprehended. Natural person and legal entity are taxed differently in the futures markets exchange, and there are some differences between the proper classifications of legal entity, related with the way it is charged. Done this characterization, it was studied in a more accurately manner, some costs related with natural persons, applied to Brazilian futures markets traded at BM\&F. The costs analyzed were: tributes (IRPF and CPMF), exchange and brokers fees, margin and cash settlement. It was proposed three different and complementary methods, to make possible the measurement and the understanding. The first method was based in 
historical price series; the second one utilized Monte Carlo simulation, based on ARIMA-GARCH models; the last method also used simulation techniques, but with a simpler theoretical model. The results demonstrated that in certain situations the costs can be very large. So, futures markets researches that consider absence of costs, or that use only the exchange and brokers fees in their analyzes, can be incurring in considerable mistakes. To present an evidence of this argument, it was obtained, for example, average transaction costs between 2 and $6,5 \%$ of the initial value of the contract. The methods utilized allowed to analyze the influence of the several factors in the transaction cost value: the length of operation, the degree of capitalization of the agent, volatility and type of operation (selling or buying contracts). It was concluded that the transaction costs analyzed is large dependent of the futures price trajectories during the period of the contract. Considering that in the beginning of the operation the real trajectory that will be verified is not known (uncertain), it implies in a risk cost that can be asymetric between the buyer and seller of the contracts. The risk cost diminishes the risk management benefits offered by futures markets, having a similar effect of basis risk. However, the former one does not depend on spot market operations, something that does not happen when the subject is basis. 


\section{INTRODUÇÃO}

\subsection{Justificativa do trabalho}

As diversas bolsas que negociam contratos futuros, no mundo, possuem uma ampla gama de derivativos, tais como dólar, ouro, índices, dentre outros, sendo que o volume negociado de alguns desses contratos corresponde a várias vezes o volume existente do ativo no mercado físico. Em se tratando de derivativos agropecuários, a própria história do surgimento dos mercados futuros está intimamente associada à comercialização agrícola. Entretanto, o uso desse instrumento pelo setor agropecuário brasileiro ainda é pouco difundido. Tal fato vem despertando o interesse da comunidade acadêmica na busca de entender a natureza dessa baixa utilização dos mercados futuros brasileiro, quando comparados ao seu volume de operações no mercado físico.

Exemplos desses esforços são trabalhos envolvendo: estudos da viabilidade dos mercados futuros de determinadas commodities (Sousa, 1996; Rochelle, 2000), utilização de contratos futuros como complemento a outros instrumentos de comercialização agrícola (Gonzalez, 1999), estimativa da razão ótima de hedge (Oliveira, 2000), uso de contratos futuros agropecuários em carteiras de investimento (Mattos, 2000), análise comparativa da eficiência do hedge entre bolsas (Perobelli, 2001), dentre outros.

O presente estudo pretende contribuir para um melhor entendimento das causas que podem contribuir para um baixo volume de contratos futuros negociados em certos mercados, fundamentando-se na magnitude relativa dos custos e benefícios advindos de

sua utilização por agentes econômicos. Particularmente, a pesquisa verifica a participação dos custos de transação, sendo eles: os tributos cobrados nas operações com 
derivativos, as taxas cobradas pela bolsa e corretoras, assim como as despesas financeiras associadas ao depósito de margem e ajustes diários.

São examinados indícios que sugerem que esses tributos e despesas financeiras, que por sua vez dependem da estrutura organizacional do agente econômico, podem ter uma magnitude muito mais expressiva do que a representada pelas taxas operacionais associadas a emolumentos, taxa de registro e taxa operacional básica, que são os custos mais explícitos de operações em futuros. Nesse contexto, pode ser que em algumas situações, os benefícios decorrentes das operações em mercados futuros sejam ultrapassados pelos custos de sua realização, o que inibiria um volume maior de negociação. Portanto, uma melhor caracterização e quantificação desses custos, podem auxiliar no entendimento da explicação de baixos níveis de atividade observados em certos mercados.

\subsection{Objetivos}

- Identificar, através de revisão de literatura e entrevistas com agentes de mercado e especialistas, os potenciais custos de transação inerentes a operações em mercados futuros

- Propor duas sistematizações: a) dos custos de transação, e b) dos tributos incidentes em mercados futuros

- Medir, através de estudo de caso envolvendo o mercado futuro do milho, alguns custos de transação, em particular: a) custos relativos à tributação incidente em mercados futuros; b) custos financeiros associados ao depósito de margem de garantia; c) custos financeiros associados à necessidade de pagamento de ajustes diários; d) taxas de bolsa e corretoras

- Verificar as diferenças nas magnitudes dos custos relacionadas ao: i) intervalo de duração entre o início e o fim de um contrato e ii) estrutura financeira do agente que faça a operação 


\subsection{Estrutura do trabalho}

O presente trabalho está dividido em sete capítulos principais.

- CAPÍTULO 1: justificativa do trabalho e objetivos

- CAPÍTULO 2: revisão de literatura sobre função econômica dos mercados futuros, descrição dos agentes desse setor e definições importantes

- CAPÍTULO 3: revisão de literatura sobre custos de transação, utilização desse conceito nos mercados futuros e modelagem de como os custos de transação podem influenciar na decisão de um agente entre operar ou não em bolsa

- CAPÍTULO 4: apresentação da metodologia utilizada para a obtenção das sistematizações propostas e para o cálculo de certos custos de transação

- CAPÍTUlO 5: sistematização dos custos de transação e distinção da cobrança de tributos para pessoas física e jurídica

- CAPÍTULO 6: cálculo dos custos de transação referentes a: taxas de bolsa e corretoras, margem de garantia, ajustes diários e tributação

- CAPÍTULO 7: considerações finais sobre o trabalho 


\section{MERCADOS FUTUROS}

\subsection{Origem}

Entender a origem e o processo evolutivo dos mercados futuros, segundo Hieronymus (1977), é útil para identificar as funções delegadas aos agentes desses mercados, determinar qual o objetivo das operações em futuros e para formar opiniões sobre mudanças no sistema que precisarão ser feitas ao longo do tempo. Talvez, continua o autor, o mais importante em estudar tais negociações através de uma percepção histórica seja com o objetivo de possibilitar um uso mais efetivo desses mercados, ou seja, compreender sua evolução é útil para entender o presente e, assim, obter sucesso nas operações futuras.

Hull (1996) cita que a história desses mercados tem sua origem na Idade Média, em que produtores agrícolas e comerciantes reuniam-se em um mesmo local para negociar antecipadamente a compra e a venda de seus produtos. Porém, mercados futuros organizados como conhecido atualmente, surgiram com a Chicago Board of Trade (CBOT) no ano de 1848. Inicialmente, essa bolsa era utilizada apenas como ponto de encontro entre agentes do mercado e tinha a função de padronizar e verificar a qualidade dos grãos.

Como destacado por Hieronymus (1977), mercados futuros não foram uma invenção imposta ao mercado vigente à época de seu surgimento, mas sim, responderam à necessidade de melhorar o desempenho de um sistema que não funcionava adequadamente, mostrando-se como um refinamento e extensão das práticas já existentes. $\mathrm{O}$ autor ainda ressalta que, uma das formas dos mercados futuros demonstrarem sua importância econômica, é devido a sua longa existência, e que, não 
fosse assim, depois de tantas oposições políticas sofridas, tal instrumento teria desaparecido.

Antes do desenvolvimento dos mercados futuros, segundo Houthakker (1959), um dos problemas sofridos por compradores de produtos agrícolas era não sabiam, com certeza, quando suas mercadorias chegariam e com que qualidade, além do risco de preço. Isso fez com que surgissem contratos denominados to arrive, que não estabeleciam precisamente o dia da entrega, mas era especificado exatamente o preço e a qualidade do produto a ser entregue. Esse contrato resolveu alguns dos problemas, sendo que os acertos adicionais entre as partes eram feitos apenas se as especificações do produto não fossem as mesmas que as acordadas.

Houthakker (1959) ainda explica que a transição do contrato to arrive para contratos futuros deu-se de maneira na qual o primeiro, gradualmente, foi tornando-se padronizado para atrair um grande número de comerciantes e, assim, reduzir os custos de encontrar um comprador ou vendedor. Todavia, ainda faltava definir um período para a entrega, pois cada negócio era feito em datas distintas. Logo, alguns meses tornaramse mais atrativos que outros para que se concretizassem as negociações.

Ainda segundo o autor, devido às características do contrato to arrive terem-se tornado tão flexíveis, a identidade dos compradores deixou de ser algo tão importante para os vendedores, além de atrair uma gama considerável de especuladores que não estavam interessados no produto (apenas nas flutuações de preço), proporcionando liquidez ao mercado. Dessa forma, os contratos eram concebidos de forma cada vez mais impessoal e o desenvolvimento de um órgão independente para intermediar as operações entre compradores e vendedores acabou, por fim, desconfigurando os contratos to arrive por completo, surgindo então, os contratos futuros.

Hieronymus (1977) também destaca cinco razões para o grande interesse em mercados futuros: 1) são mercados que negociam preços e, estes, por sua vez, influem na receita dos agentes; 2) agentes de mercado utilizam esse instrumento como estratégia de compra e venda de seus produtos; 3) são de interesse acadêmico por tratarem de formas de comercialização e organização de mercados; 4) são fontes de renda para inúmeras pessoas pois, as bolsas possuem uma gama vasta de empregados, além de corretores, 
especuladores, empresas de consultoria, que de uma forma ou de outra se beneficiam desse tipo de negociação; 5) são de interesse público, pois várias pessoas negociam contratos futuros devido à facilidade de entrada.

Mulherin et al. (1991) argumenta que a análise econômica de organizações como as bolsas de futuros não são meramente exercícios intelectuais. Tal análise tem não só uma importância acadêmica como também serve de guia para ações políticas das agências que regulam esse sistema. Portanto, conclui-se que o estudo de mercados futuros assume grande relevância na ciência econômica e que, compreender melhor sua origem, evolução, funcionamento e importância, é fundamental para os pesquisadores dessa área.

\subsection{Função econômica}

Working (1953), importante autor na área de derivativos ${ }^{1}$, propôs uma definição na qual mercados futuros são negociações feitas sob regulamentação e convenções especiais, mais restritivas que as aplicadas em outras classes de transações com commodities, as quais servem, primariamente, para facilitar a proteção contra preços (hedging) e especulação, promovendo uma excepcional conveniência e economia nos custos de transação.

Outra abordagem é dada por um grande estudioso dos mercados futuros. Hieronymus (1977) refere-se explicitamente aos mercados futuros como um jogo. Enfatiza que esses mercados possuem diferentes significados para cada tipo de indivíduo. Cita, por exemplo, que para especuladores significam oscilações de preço com ganhos e perdas, para produtores são garantia de receita e disponibilidade de crédito, e para corretores são volume de contratos negociados.

\footnotetext{
${ }^{1}$ Segundo Hull (1996) derivativos podem ser definidos como títulos cujos valores dependem de outras variáveis mais básicas, sendo que contratos futuros e de opções são exemplos de derivativos. Cita que no caso de contratos futuros de trigo, esse é um derivativo porque seu valor depende do preço do trigo no mercado físico.
} 
$\mathrm{O}$ autor argumenta que esse fenômeno se estende para os demais agentes do mercado, cabendo aos economistas decifrar tais visões, agregá-las, e buscar definir as principais funções do mercado de derivativos.

Dessa forma, surge uma questão pertinente para o estudo dos mercados futuros que é a de definir qual sua função econômica e porque os agentes operam em tal instrumento. Esse debate vem ocorrendo há décadas, e o objetivo neste momento é expor as diversas visões sobre esse tema. Isso se torna importante neste trabalho à medida que, ao analisar a influência dos custos de transação nas operações em mercados futuros, diminuindo seu benefício, este deve estar claramente especificado. A definição do que se entende por função econômica dos derivativos, portanto, ajudará na compreensão da interação entre benefício e custo.

Hieronymus (1977) expõe que cada economista tem sua lista de funções dos mercados futuros. Para fins deste trabalho, será feita uma distinção de duas correntes básicas de pensamento quanto a esse tema. Autores como Hieronymus (1977), Hirshleifer (1988), Leuthold et al. (1989), Duffie (1989), Ennew et al. (1992), Harwood et al. (2002), dentre outros, defendem que mercados futuros servem, primariamente, para reduzir risco de preços. A seguir é apresentada uma compilação das idéias principais desses autores quanto à função dos mercados futuros:

- transferir (administrar) risco

- permitir maior competitividade no mercado

- facilitar empréstimo de terceiros

- possibilitar especulação

- prover informações sobre preços futuros, auxiliando nas estratégias dos agentes

- aumentar o escopo e flexibilidade das decisões estratégicas

- servir de substituto às integrações verticais que objetivem diminuir riscos

Apesar dessa extensa lista de possíveis benefícios do mercado de derivativos, todos os autores são enfáticos em afirmar o papel fundamental de administração de risco. Duffie (1989) chega a afirmar que contratos futuros são, essencialmente, contratos de seguro de preço, provendo proteção contra as incertezas contratuais do mercado à 
vista para entrega futura. Leuthold et al. (1989) chamam a atenção para o fato de que firmas não precisam, necessariamente, participar de negociações em futuro para se beneficiarem dele, pois as informações, traduzidas nos preços, fluem livremente. Logo, completa o autor, a transferência de risco seria a razão principal dos agentes operarem em tal mercado.

Corroborando essas opiniões, Hieronymus (1977) cita que a visão de que a função básica dos mercados futuros é a de transferência de risco é suportada analisandose a história e o desenvolvimento desse mercado. Explica que antes do surgimento de mercados organizados, os agentes não eram financeiramente capazes e não queriam tomar risco, e que seus bancos não estavam dispostos a financiá-los porque grandes perdas poderiam acabar com o negócio. Sendo assim, cita que mercados futuros vieram viabilizar e minimizar os problemas dessas transações. Cabe destacar que Hieronymus (1977) alerta que o papel de administração de risco não impede que os agentes de mercado utilizem derivativos de maneira especulativa.

Contudo, alguns autores questionam a visão comum de mercados futuros como sendo, fundamentalmente, um instrumento de transferência de risco. Working (1953), lançando a semente para essa nova corrente de idéias, afirma que operar em bolsa é uma forma de arbitragem, baseado na variação relativa dos preços físico e futuro. $\mathrm{O}$ fato de que os riscos são menores com ou sem essa operação seria, freqüientemente, um fator secundário. Houthakker (1959) chega a argumentar que entender mercados futuros como apenas um instrumento de redução de risco, é uma visão muito simplista.

Assumir a administração de risco como principal motivo dos agentes operarem em bolsa, na opinião de Working (1953), é desviar a atenção do que seria possivelmente o mais importante serviço desse tipo de mercado, que é o de promover um ajuste econômico desejável dos estoques de commodities, com conseqüente redução da flutuação dos preços. Houthakker (1959) também expõe que a redução do risco de preço é condição necessária, mas não suficiente, para o sucesso de uma operação em futuros. Explica que há outros fatores como diferenças de disponibilidade de crédito para ativos que são negociados ou não, além dos custos envolvidos na operação em bolsa, que podem ser altos a ponto de inviabilizar a negociação. 
Telser \& Higinbotham (1977), foram dois importantes autores que desenvolveram as idéias lançadas por Working. Os autores citam que, além de um possível seguro de preço, mercados futuros organizados têm a importante propriedade de atrair compradores e vendedores de um limite geográfico considerável. Isso aumentaria a heterogeneidade das potenciais transações, mas reduziria a dispersão da distribuição dos preços, dado o alto volume negociado. Isso significa, como expresso nas idéias de Houthakker (1959), que esses autores justificam a existência das bolsas por reduzirem o custo de transação das negociações, deixando a administração de risco como um benefício secundário.

Tal ponto de vista pode ser resumido nas idéias de Williams (1987), o qual expõe que com a concentração das negociações em um mesmo local e presença de especuladores dando liquidez, os custos de transação desses mercados são extremamente baixos quando comparados às transações do mercado físico, onde o volume negociado é fragmentado em distintas qualidades do produto, localização e termos de entrega. Notase, portanto, que em uma visão mais abrangente, mercados futuros desempenham múltiplos papéis além da redução de risco. Williams (1986) também critica duramente a visão de que mercados futuros seriam apenas um seguro do preço.

Telser \& Higinbotham (1977) concluem que os benefícios trazidos por mercados futuros organizados são advindos do fato de facilitar transações entre estranhos. Isso seria conseguido através de regulação pela bolsa, que oferece garantias e padronização de contratos, diminuindo os custos de risco moral ${ }^{2}$. Alegam que um contrato de longo prazo depende da integridade das partes envolvidas, contudo, esse problema é atenuado em um mercado com muitos participantes e garantido por uma bolsa. Portanto, segundo os autores, o produto a ser transacionado deve ter escala suficiente para reduzir os custos de transação, e os preços refletiriam com maior eficiência as perspectivas dos agentes envolvidos (Cox , 1976).

\footnotetext{
${ }^{2}$ Segundo Milgrom \& Roberts, risco moral (moral hazard) é definido como uma forma de oportunismo pós-contratual, em que uma das partes possui conhecimento maior que outra, e utiliza desse fato para seu próprio benefício, em detrimento da parte menos informada.
} 
Concluindo, tem-se que a apresentação das diferentes visões sobre a função de mercados futuros, principalmente quanto ao papel da administração de risco, é importante para o entendimento dos benefícios em mercados futuros. Isso porque será argumentado que, para um agente individual, o principal benefício de negociar contratos futuros seria a redução do risco de preço e, nesse caso, os custos transacionais poderiam inibir o uso de tal instrumento. Mesmo não havendo consenso sobre a função econômica dos mercados futuros, em se tratando da visão de transferência de risco, a teoria de decisão em ambiente de incerteza é um referencial teórico amplamente utilizado, sendo, neste trabalho, a forma de se justificar a importância da mensuração dos custos de transação a ser feita.

\subsection{Mercados futuros agropecuários}

Depois de exposta a opinião de diferentes autores sobre as funções econômicas de mercados futuros, caberá nesse momento caracterizar, mais especificamente, o uso desse instrumento no setor agropecuário. Tal análise é importante não só para justificar a relevância de mercados futuros nesse segmento econômico, mas também devido a sua origem estar diretamente relacionada com a comercialização de produtos agrícolas. Ademais, o cálculo dos custos de transação em mercados futuros nesta pesquisa, bem como a maioria dos exemplos elucidativos que se seguem, são referentes ao mercado de derivativos agropecuários.

Um fato interessante, relatado na literatura especializada, é que os mercados futuros agrícolas, de maneira geral, foram alvo de transformações significativas ao longo do tempo e objeto de muitos estudos econômicos. Um exemplo dessas mudanças é citado por Gardner (2000). Ele cita que, tanto no Canadá como nos Estados Unidos, o governo está a algum tempo saindo de um papel altamente regulador, dando maior ênfase na administração de risco por parte dos próprios agentes. Essas mudanças afetam sobremaneira seus incentivos e suas percepções quanto ao uso de mercados futuros.

Outro exemplo de mudança é dado por Leuthold et al. (1989), ao exporem que nos mercados futuros norte-americanos, contratos agrícolas tiveram grande importância no aumento do volume negociado no início dos anos 70 devido à elevação dos preços de 
commodities e energia. Posteriormente, um segundo aumento no volume de contratos negociados ocorreu face à introdução de instrumentos financeiros, em que mudanças na conjuntura mundial fizeram crescer o interesse sobre contratos futuros de índices. Tais mudanças no início dos anos 80 foram tão dramáticas que a participação das commodities agropecuárias, nos Estados Unidos, caiu drasticamente.

Mesmo assim, o mercado de derivativos mundial ainda possui grande relevância na comercialização de diversas commodities, principalmente naquelas que possuem um ativo comércio internacional. Para exemplificar a importância dessa modalidade de negociação, a Tabela 1 mostra que o volume negociado de milho, soja e trigo, em uma das principais bolsas do mundo (a Chicago Board of Trade - CBOT), é algumas vezes superior à produção mundial.

Tabela 1. Volume de contratos agrícolas negociados na CBOT e suas respectivas produções agrícolas mundiais, no ano de 2001.

\begin{tabular}{ccccc}
\hline & $\begin{array}{c}\text { Número de } \\
\text { contratos } \\
\text { negociados na } \\
\text { CBOT }\end{array}$ & $\begin{array}{c}\text { Volume Negociado } \\
\text { na CBOT } \\
\text { (em 1000 ton) }\end{array}$ & $\begin{array}{c}\text { Produção } \\
\text { Mundial } \\
\text { (em 1000 ton) }\end{array}$ & $\begin{array}{c}\text { Número de vezes a } \\
\text { produção mundial }\end{array}$ \\
\hline Milho & 16.728 .748 & 2.124 .640 & 585.920 & 3.6 \\
Soja & 12.150 .369 & 1.653 .394 & 176.638 & 9.4 \\
Trigo & 6.801 .541 & 925.538 & 582.692 & 1.6 \\
\hline
\end{tabular}

Fonte: dados primários extraídos do site da $\mathrm{CBOT}^{3}$ e $\mathrm{FAO}^{4}$, com cálculos elaborados pelo autor.

Esse volume relativamente expressivo de negociações de algumas commodities, mais especificamente no setor agropecuário, segundo Marques \& Mello (1999), é advindo de vantagens como:

\footnotetext{
${ }^{3}$ http://www.cbot.com/cbot/docs/22551.pdf

${ }^{4}$ http://www.fao.org
} 
- Todos aqueles que têm interesse em uma determinada mercadoria física podem se proteger contra oscilações de preço desfavoráveis no futuro.

- Através das expectativas de oferta e demanda, os mercados futuros são os melhores sinalizadores dos preços futuros, ou seja, têm a função de "descobrir preço".

- Além de assegurar determinada rentabilidade, contribuem para diminuir a sazonalidade de preços da produção agropecuária.

- Os mercados futuros atraem capital de risco (investidores e especuladores). Dessa forma, estes assumem os riscos e contribuem para uma maior liquidez do mercado.

- Devido à conseqüente diminuição de risco através do hedge, produtores rurais podem ter melhores condições de adquirir financiamentos junto às instituições financeiras.

Com relação ao Brasil, a história dos mercados futuros teve origem com a Bolsa de Mercadorias de São Paulo (BMSP), criada em 1917, com operações a termo de diversas commodities agropecuárias. Em 1985 surgiu a Bolsa Mercantil \& de Futuros $(B M \& F)$. Seis anos mais tarde, a BMSP e a BM\&F fundiram-se utilizando a mesma sigla desta última, porém, com o nome de Bolsa de Mercadorias \& Futuros. Em 1997, a $\mathrm{BM} \& \mathrm{~F}$ uniu-se à Bolsa Brasileira de Futuros (BBF), sediada no Rio de Janeiro, tornando-se a única bolsa de futuros do Brasil. A BM\&F é hoje o principal centro de negociação de derivativos do Mercosul.

A BM\&F possui contratos para diversos produtos agropecuários, tais como: açúcar cristal, álcool anidro, boi gordo, café, milho, soja, dentre outros. Entretanto, esses contratos não possuem um volume significativo de negociação, quando comparado à outras bolsas internacionais. Dos produtos citados, os que possuem maior liquidez na BM\&F, ou seja, maior volume de contratos negociados são: café arábica, boi gordo, açúcar e álcool anidro. Veja na Tabela 2 a evolução das principais commodities agropecuárias negociadas na $\mathrm{BM} \& \mathrm{~F}$ nos últimos anos. 
Tabela 2. Evolução do volume de contratos negociados na BM\&F (1996-2002).

\begin{tabular}{ccccc}
\hline Ano & Café arábica & Boi Gordo & Açúcar & Álcool \\
\hline 1996 & 116.071 & 119.092 & 6.212 & - \\
1997 & 114.521 & 109.261 & 8.330 & - \\
1998 & 198.547 & 88.054 & 30.080 & - \\
1999 & 317.722 & 123.442 & 33.764 & - \\
2000 & 390.513 & 150.410 & 52.52 & 53.963 \\
2001 & 475.034 & 92.365 & 93.904 & 67.527 \\
2002 & 446.115 & 152.560 & 48.326 & 62.896 \\
\hline
\end{tabular}

Fonte: dados extraídos de Perobelli (2001) e atualizados com dados através do site da $\mathrm{BM} \& \mathrm{~F}$.

Perobelli (2001) afirma que, mesmo com um baixo volume de negociação, este tem aumentado constantemente ao longo dos últimos anos. Segundo a autora, o crescente desempenho do setor agropecuário deve-se, principalmente, à abertura de contratos para não residentes (internacionalização da bolsa) e devido a um maior conhecimento dos agentes de mercado sobre a cultura do hedge.

\subsection{Caracterização dos Agentes do Mercado Agropecuário}

Caracterizada a importância dos derivativos agropecuários na economia, cabe, nesse momento, uma análise dos agentes desse mercado que, ou operam, ou são potenciais usuários de mercados futuros. Tal análise já traz alguns elementos dos motivos que levariam um indivíduo a fazer ou não uma operação em futuros, e a influência que os diversos tipos de organizações, e as diversas formas de estruturas, possuem na percepção dos custos e benefícios da operação.

Ennew et al. (1992) citam que apesar do grande interesse da literatura sobre o funcionamento dos mercados futuros, até então, pouca atenção era dada na identificação de quais agentes operavam nesse mercado. Porém, alguns trabalhos buscaram responder tal questão. Um dos exemplos é o trabalho de Collins (1997), que obteve evidências 
empíricas de como arbitradores, processadores e produtores comportam-se com relação aos mercados futuros.

Primeiramente, o autor define arbitradores como sendo pessoas que emprestam dinheiro de terceiros, compram o produto desejado no mercado físico e, simultaneamente, vendem igual quantidade em mercados futuros. O segundo tipo de agente, os processadores, são as empresas que utilizam matéria-prima produzida pelo setor primário para fabricar seu produto final. Por último, os produtores são os que fornecem a matéria-prima. $O$ autor argumenta que esses três agentes têm comportamentos diferentes porque respondem a distintos estímulos econômicos. Tal argumentação já traz à luz como diferentes estruturas organizacionais comportam-se diferentemente nas suas escolhas.

Collins (1997) afirma que, em geral, arbitradores fazem hedge de toda sua posição no mercado físico. Já os processadores negociam apenas parte de seu produto, enquanto produtores agrícolas raramente, ou nunca, realizam tal operação. $\mathrm{O}$ autor relata algumas evidências da literatura, citando que: Berck ${ }^{5}$ em 1977 calculou que apenas 5\% dos produtores agrícolas faziam hedge; Shapiro \& Brorsen ${ }^{6}$, em 1985, entrevistaram produtores com bom nível de instrução e avaliaram que nos últimos cinco anos, eles fizeram uma média de apenas 11,4\% de hedge da área total plantada; e Sapp ${ }^{7}$, em 1992, fez pesquisa junto a pecuaristas em Iowa, e verificou que somente $18 \%$ deles já haviam utilizado mercados futuros.

Collins (1997) cita que apesar de muitos trabalhos publicados recomendarem aos produtores agrícolas que façam hedge de parte substancial de sua produção, ano após ano, milhares de produtores continuam não participando desse mercado. Ennew et al. (1992), citando Makus et al. $(1990)^{8}$, expõem que em pesquisa feita com produtores

${ }^{5}$ BERK, P. Portfolio theory and the demand for futures: the case of California cotton. American Journal of Agricultural Economics, v.63, n.3, p.466-74, 1981.

${ }^{6}$ BRORSEN, B.W.; SHAPIRO, B.I. Factors influencing farmers' decision of whether or not to hedge. Agricultural Economics, v.10, n.2, p.145-53, 1988.

7 SAPP, S.G. Producers' opinions of the Iowa cattle industry. Ames: Iowa State University, 1992. $122 \mathrm{p}$.

${ }^{8}$ MAKUS, L.D.; LIN, B.H.; CARLSON, J.; KREBILL-PRATHER, R. Factors influencing farm level use of futures and options in commodity futures marketing. Agribusiness, v.6, p.621-631, 1990. 
rurais norte-americanos, foi notado que fatores como experiência de utilização de contrato a termo, educação, tamanho da propriedade e localização, poderiam de certa forma explicar o comportamento negativo de tais agentes quanto aos mercados futuros.

Hirshleifer (1988), citando Paul et al. ${ }^{9}$, comenta que a maioria das operações de hedging em mercados futuros é feita por intermediários que possuem o produto agrícola $\left(\right.$ elevators $^{10}$ ), e não por produtores, sendo tal fenômeno também relatado por Gardner (2000). Segundo Hirshleifer (1988), um dos motivos que levam a isso é que os produtores se protegem via contrato a termo, que de certa forma substitui a operação de hedge. Nelson (1985), mesmo não concordando com a idéia de que contratos futuros e a termo são substitutos perfeitos, também afirma que produtores preferem, evidentemente, estes últimos.

Hirshleifer (1988) ainda defende que uma segunda razão que faz com que produtores não façam hedge, é que uma propriedade rural, em geral, é um empreendimento relativamente de pequeno porte. Dessa forma, os custos de se aprender como negociar em mercados futuros podem ser um significativo empecilho para produtores. Working (1953), à sua época, também já citava que produtores rurais raramente operavam em bolsa de futuros.

Gardner (2000), por outro lado, expõe que a causa para a baixa participação percentual dos agricultores norte-americanos em instrumentos de administração de risco é resultado da não participação dos pequenos produtores, que correspondem a grande parte do total. Estes recebem a maior parte de sua renda de outras origens, que não a agricultura. Logo, seu portifólio já é altamente diversificado e, uma adicional estabilização da renda da agricultura, não alteraria de maneira intensa a sua renda total. Isso faz que produtores de larga escala tendam a utilizar mais instrumentos de

\footnotetext{
9 PAUL, A.B.; HEIFNER, R.G.; HALMUTH, J.W. Farmers' use of forward contracts and futures markets. Agricultural Economics Report, v.32, n.11, p.1-20, 1976.

${ }^{10}$ Segundo Marques \& Sousa (1997), elevators são um misto de armazéns gerais e cerealistas, já que suas receitas vêm tanto da compra e venda de grãos, como de serviços de secagem e armazenamento para produtores e processadores. Quase a totalidade de grãos comercializados nos Estados Unidos passa pelos Elevators, pois exercem um papel fundamental à medida que possibilitam ganhos de eficiência e maior competitividade no preço do produto.
} 
administração de risco. Gardner (2000) cita que o USDA, em pesquisa feita em 1996, verificou que mais de $40 \%$ dos agricultores com renda superior a quinhentos mil dólares, utilizavam mercados futuros.

Harwood et al. (2002), corroborando essa evidência, citam estudo indicando que $82 \%$ do total de produtores agrícolas tinham renda extra-agricultura maior que a renda agrícola. Porém, os autores alertam que a análise de produtores americanos pode ser enganosa, pois um terço desses produtores, à época, recebiam alguma forma de subsídio do governo. Contudo, argumentam que com a crescente liberalização das políticas agrícolas desse país, os instrumentos de administração de risco tendem a crescer.

Ennew et al. (1992), por sua vez, argumentam que fatores subjetivos como informações boca a boca, informativos distribuídos pelas empresas, podem contribuir para uma má percepção dos potenciais usuários dos mercados futuros, influindo na confiabilidade daqueles para com a instituição. Os autores estudaram quais as principais barreiras para o não uso de mercados futuros pelos agentes do mercado de batata, em Londres. Verificaram que os indivíduos que já haviam utilizado derivativos destacavam como principais barreiras: risco de entrega física, pouca relação entre preço futuro e físico, e instabilidade no mercado. Já os que nunca havia operado em futuros, percebiam como entraves: incerteza sobre o benefício, outros não viam benefício algum, e ausência de informação sobre o mercado.

Barros (1997) discute e comenta algumas experiências norte-americanas no incentivo para produtores rurais participarem mais ativamente de negociações em mercados futuros. Cita exemplos de alguns programas implementados pelo governo dos Estados Unidos que buscavam dar treinamento e suporte financeiro para que produtores fizessem operações de hedge. O resultado foi que a grande maioria desses programas de incentivo fracassou.

Collins (1997) expõe que justificar que agricultores não operam em mercados futuros devido à falta de conhecimento desse instrumento não é uma explicação satisfatória nem consistente com evidências empíricas, chegando a afirmar que modelos que recomendem o hedging para produtores agrícolas devem ser questionados. Por outro lado, Williams (1986) defende que as pessoas que possuem o produto físico precisam ser 
os principais agentes a serem analisados, pois são eles, e não especuladores e corretoras, que possuem maior influência sobre padrões de preço e conseqüente viabilidade dos mercados futuros.

Apesar das evidências de produtores rurais não operarem em bolsa, é importante ressaltar que mudanças nas formas contratuais utilizadas pela sociedade são, geralmente, um longo processo, particularmente quando há pouca experiência com os contratos que melhor se ajustam a uma nova situação. É também razoável de se esperar que uma sociedade que tenha longa tradição em certo tipo de tecnologia e uma estável perspectiva de preços relativos, busque formas contratuais que minimizem custos para cada tipo de produção, dado o estado de conhecimento sobre arranjos contratuais e a estrutura básica de direitos de propriedades (Eggerstsson, 1990).

Portanto, através da revisão de literatura, nota-se que a forma da estrutura organizacional (principalmente no que tange a pequenos e grandes produtores) influencia no comportamento dos agentes quanto à utilização de mercados futuros. A análise de como as estruturas organizacionais influenciam na decisão dos indivíduos, é também um dos objetivos deste trabalho. Porém, nesta pesquisa, a distinção básica refere-se à forma como os indivíduos e firmas são tributados.

\subsection{Conceitos importantes}

Nesta parte serão explorados alguns conceitos importantes sobre operações em mercados futuros e imprescindíveis para o desenvolvimento e entendimento das principais idéias do trabalho. Primeiramente será apresentado o significado de hedging, que é geralmente definido como o ato de comprar ou vender contratos futuros, assumindo posição inversa à do mercado físico, de forma a assegurar um preço desejado (Marques \& Mello, 1999).

Já hedgers são os vendedores e compradores de contratos futuros que ou têm o produto ou têm interesse no mercado. Geralmente o hedger, ao contrário do especulador, está preocupado em assegurar seu preço de compra ou venda no mercado físico, como por exemplo, produtores rurais e cooperativas, bem como agroindústrias e exportadores (Marques \& Mello, 1999). 
Outro conceito importante é o de base, que é definida como a diferença entre o preço físico da região onde o hedger se encontra e o preço negociado em bolsa. Segundo a Futures Industry Institute (1998), a base é um elemento crucial, pois sem seu conhecimento não é possível determinar, com precisão, o preço pelo qual se deseja fazer o hedge. Isso porque, na data de abertura da operação, não se sabe qual a diferença entre o preço futuro em que se encerrará a operação e o preço do mercado físico.

Uma oscilação na base do início para o final do contrato afeta de maneira inversa o lado comprador e o lado vendedor do contrato. Assim, ao iniciar um contrato futuro, deve-se ter em mente que há um risco de base que pode ser favorável ou não, dependendo da posição assumida (comprada ou vendida). Mas segundo a Futures Industry Institute (1998), mesmo havendo risco de base, este é muito mais previsível que flutuações de preços da maioria das commodities, culminando no fato que os hedgers aceitam eliminar o risco de preço e retém o de base, que possui um risco menor (uma clara caracterização desse conceito pode ser encontrada em Hull, 1996).

Associado à definição de base, surge o conceito de hedge perfeito, que segundo Hull (1996) é aplicado quando na data de abertura de um contrato a base do período futuro é conhecida. Dessa forma, o vendedor ou comprador do contrato eliminaria todo seu risco, conseguindo obter exatamente o preço que havia planejado. Apesar de o hedge quase nunca ser perfeito (Hull, 1996), tal definição ajuda na simplificação de análise de mercados futuros, em que se tem um seguro de preço sem incertezas, permitindo assim a focalização da atenção em problemas de outra natureza.

Uma outra definição é a de razão de hedge. Hull (1996) define-a como sendo a quantidade de contratos futuros negociados com relação à extensão do risco. Isso quer dizer que a proporção de contratos futuros a ser comprada/vendida, em relação ao produto físico a ser transacionado, deve ser tanto maior quanto mais elevado for o risco. Logo, pode-se dizer que não se faz, necessariamente, um hedge de $100 \%$ do produto a ser transacionado. Tal fato influencia diretamente no montante de custo e benefício das operações, dado que esses fatores são dependentes do volume negociado.

Existem alguns modelos que buscam calcular o tamanho ótimo de contratos a serem negociados em mercados futuros, porém, a análise e discussão de tais modelos 
fogem do escopo deste trabalho. Para um estudo mais aprofundado sobre o assunto, Myers \& Thompson (1989) e Haigh \& Holt (2000), são algumas das referências bibliográficas acerca do cálculo de razão de hedge.

Uma característica marcante dos mercados futuros é a necessidade do depósito de margem de garantia. Ela configura-se por ser um depósito, em ativos financeiros ${ }^{11}$, exigido pela bolsa, proporcional ao valor do contrato negociado e definido a critério da instituição. Deve ser depositada no dia útil subseqüente ao de abertura da posição. $\mathrm{Na}$ $\mathrm{BM} \& \mathrm{~F}$, hedgers recebem um desconto de $20 \%$ do valor cobrado, quando comparados aos especuladores. Além da margem inicial, a bolsa (mais precisamente, a Câmara de Compensação) pode fazer chamadas adicionais de margem, que consiste em um depósito extra de ativos financeiros durante a vida do contrato. Esse fato ocorre, por exemplo, quando um contrato é negociado em dólar e a margem é depositada em reais. Se houver uma desvalorização muito brusca do real frente ao dólar, é feita uma chamada de margem para voltar ao nível inicial.

Baer et al. (1996) citam que há duas correntes de opiniões sobre a justificativa do depósito de margem: a primeira argumenta que a margem é uma ferramenta de controle do excesso de volatilidade; a segunda fala do interesse da bolsa em proteger-se contra inadimplência, tendo para isso que calcular o nível de margem adequado. Os autores argumentam que a segunda visão seria a mais adequada, concordando, dessa forma, com as idéias de Telser (1981) e Hartzmark (1986). Outros dois autores, Fenn \& Kupiec (1993), expõem que a bolsa busca calcular a margem ótima a ser depositada, ou seja, procura impor um nível que minimize o risco de inadimplência, mas que não cause um impacto negativo na demanda por contratos futuros.

De um modo mais simples, a margem de garantia pode ser vista como um instrumento que oferece maior segurança ao sistema de bolsas, sendo seu valor ao redor de $10 \%$ do valor total negociado (Leuthold et al., 1989). O risco de inadimplência por

\footnotetext{
${ }^{11}$ Os ativos aceitos como margem de garantia pela BM\&F são: "para residentes, dinheiro, títulos públicos federais, ouro, cotas do Fundo dos Intermediários Financeiros (FIF) e, mediante autorização prévia da Bolsa, títulos privados, cartas de fiança, ações e cotas de fundos fechados de investimento em ações. Para não-residentes, dólares dos Estados Unidos e, mediante autorização prévia da BM\&F, títulos do governo dos Estados Unidos (T-Bonds, T-Notes e T-Bills)". Informação obtida no site: www.bmf.com.br.
} 
parte dos clientes das corretoras, que acaba configurando a existência do depósito de margem, segundo Telser (1981), deve-se ao fato de a Câmara de Compensação não poder cobrir as possíveis inadimplências das partes que pagam o ajuste, com o dinheiro ganho pela parcela de negociadores que devem receber ajustes positivos.

Para se ter uma noção do montante a ser depositado como margem de garantia, a Tabela 3 mostra os valores para alguns contratos agrícolas da BM\&F (2003).

Tabela 3. Valor de margem de garantia, por contrato negociado, dos derivativos agropecuários negociados na BM\&F (25/08/2003).

\begin{tabular}{cccc}
\hline Contrato & Vencimento & \multicolumn{2}{c}{ Normal (R $\$$ ) } \\
\hline Açúcar & & US $\$ 275,00$ & Uedger* \\
Álcool anidro & todos & $\mathrm{R} \$ 2.400,00$ & $\mathrm{R} \$ 1.920,00$ \\
Algodão & todos & $\mathrm{US} \$ 1.250,00$ & $\mathrm{US} \$ 1.000,00$ \\
Bezerro & todos & $\mathrm{R} \$ 500,00$ & $\mathrm{R} \$ 400,00$ \\
Boi gordo & todos & $\mathrm{R} \$ 900,00$ & $\mathrm{R} \$ 720,00$ \\
Café arábica & todos & $\mathrm{US} \$ 700,00$ & $\mathrm{US} \$ 560,00$ \\
Café conillon & todos & $\mathrm{US} \$ 875,00$ & $\mathrm{US} \$ 700,00$ \\
Milho & todos & $\mathrm{R} \$ 700,00$ & $\mathrm{R} \$ 560,00$ \\
Soja & todos & $\mathrm{US} \$ 1.875,00$ & $\mathrm{US} \$ 1.500,00$ \\
\hline
\end{tabular}

Fonte: BM\&F (2003)

* Os valores em dólares são convertidos em reais pela Taxa de Câmbio Referencial BM\&F do dia.

Por fim, cabe salientar o significado de ajustes diários. Para Marques \& Mello (1999), ajuste diário é um recebimento ou pagamento diário, caso os preços se movimentem de forma contrária ou favorável à posição assumida, e servem para dar maior garantia ao sistema contra inadimplência. Na prática, todos os dias em que há negociação, ao final do pregão, a bolsa veicula um preço de ajuste, calculado com base nas transações efetuadas no dia. Esse valor é usado como referência para o pagamento 
ou recebimento de ajustes diários, sendo a Câmara de Compensação quem coordena esse acerto de contas. Maiores detalhes consultar Hull (1996) ou Marques \& Mello (1999). 


\section{CUSTOS DE TRANSAÇÃO EM MERCADOS FUTUROS}

\subsection{Interação entre Risco e Custo de Transação}

Houthakker (1959) argumenta que um dos exemplos mais ricos da interação entre custo de transação e risco é a introdução de papel moeda na economia. O autor exemplifica seu ponto de vista supondo um produtor de trigo que desejasse vender sua produção. Cita que o produtor gastaria muito tempo procurando pessoas que tivessem os produtos que ele necessitasse e que, ao mesmo tempo, aceitasse o seu trigo para fazerem a troca (escambo). Além disso, o produtor assumiria o risco de não encontrar uma contraparte para negociar quando estivesse com o produto. Dessa forma, o autor argumenta que com o surgimento do papel moeda, todo esse custo de transação e risco foram diminuído, pois poder-se-ia vender e comprar de qualquer pessoa que tivesse dinheiro, e quando fosse necessário. Isso explica a existência de moeda mesmo sem ter nenhum uso específico, a não ser como base de troca.

Com relação a contratos, de uma maneira geral, as variáveis risco e custo de transação estão associadas diretamente com o fato que todos os contratos são incompletos (Dorward, 2001). Isso ocorre, segundo Klein (1980), por dois motivo: 1) incerteza implica em grande número de possibilidades, e saber todas elas pode tornar-se inviável (custo de informação); 2) a performance pode ser difícil de mensurar, logo, quebras de contrato podem ser difíceis de comprovar legalmente, dando margem a ações oportunistas.

A interação entre risco e custo de transação pode ser resumida nas palavras de Dorward (2001)

"Informação, portanto, pode ter custo e ser assimétrica, e como as firmas e indivíduos buscam maximizar sua utilidade tendo 
racionalidade limitada em um mundo de incertezas, eles incorrem em custos de transação em adquirir essas informações e em tomar medidas de proteção contra risco de perda nas transações. Estas medidas podem envolver uma reunião de informações e o uso de formas contratuais que reduzem o risco de comportamentos oportunistas de outras partes, com o custo de reduzir incentivos, reduzir eficiência na produção, ou obter preços menos favoráveis. Exposição ao risco, portanto, torna-se fator chave em custos de transação, tal que quanto maior a exposição ao risco, maiores os custos que uma firma desejará incorrer para reduzir os riscos que ela enfrenta.(p.60, tradução do autor)".

Muitos autores consideram importante a associação dessas duas variáveis para determinar o modo com que agentes tomam decisões, mais especificamente no que tange à escolha de contratos. Outro exemplo é dado por Eggerstsson (1990), citando que Higgs $(1973)^{12}$ desenvolveu um modelo no qual mostra que mudanças no nível de risco em comunidades agrícolas afetam a importância relativa de formas contratuais. Porém, o autor conclui que apenas aversão ao risco não explica diretamente as diversas formas de arranjos contratuais e que custos de transação são elementos chaves para explicar tais variações na agricultura.

Um trabalho clássico que busca tratar dessa relação foi publicado por Cheung (1969). O autor buscou explicar a existência de diferentes contratos agrícolas em uma mesma região, através dessas duas variáveis. Hoff, Braverman e Stiglitz (1993), sendo este último autor o ganhador do Prêmio Nobel de 2001, consideram o artigo de Cheung (1969) um dos três principais textos acadêmicos para entender-se o desenvolvimento e

12 HIGGS, R. Race, tenure, and resource allocation in southern agriculture. Journal of Economic History, v.33, p.149-169, 1973. 
peculiaridades do setor agrícola ${ }^{13}$ - os outros dois trabalhos citados são o de Akerlof $(1970)^{14}$ e Stiglitz $(1974)^{15}$.

Analisando a estrutura de mercados agrícolas de algumas regiões asiáticas, Cheung (1969) observou que havia diversos tipos de contratos agrícolas (tais como arrendamento, salário e parceria) coexistindo em uma mesma área, e quando analisava diversas localidades, a proporção de cada tipo de contrato era distinta. Dada essa constatação, o autor argumentou que havia, no mínimo, duas razões para não haver a preponderância de apenas um tipo de contrato. A primeira era o risco natural que influía na variância do valor da produção. A segunda era a diferença de custo de transação associado a cada contrato. Este último fator surgiria porque a utilização de contratos envolve uma transferência parcial de direitos de propriedade, implicando em custos (distintos para cada situação particular) de negociação e de se fazer cumprir o que foi acordado.

Cheung (1969) cita que o postulado de aversão ao risco diz que um indivíduo procurará diminuir seu risco se o custo dessa ação for menor do que o ganho do risco administrado. Dessa forma, sugere que a escolha de um contrato deve ser analisada empregando tanto o postulado de aversão ao risco, como deve se levar em consideração os diferentes custos de transação de contratos. Esses dois fenômenos, segundo ele, vistos separadamente, não explicam bem a coexistência entre as várias formas de contrato verificadas empiricamente. Tais idéias expressam exatamente a essência deste trabalho.

Utilizando-se das palavras de Howard \& D'Antonio (1994), o que se argumenta é que os "benefícios do hedging oferecidos por mercados futuros vêm a um certo custo (p.237)". Considerando os benefícios de contratos futuros advindos da diminuição do

\footnotetext{
${ }^{13}$ Apesar de Hoff et al. (1993) fazerem algumas críticas sobre particularidades do trabalho de Cheung (1969), tais como que este último omitiu a necessidade de monitoramento como custo de transação, algo tratado posteriormente por Stiglitz (1974), concordam com a essência do problema levantado no trabalho de Cheung (1969) e consideram este trabalho como um dos precursores da vasta literatura moderna sobre custos de transação, iniciada por Coase (1937) em sua teoria da firma.

${ }^{14}$ AKERLOF, G. The market for lemons: qualitative uncertainty and the market mechanism. Quarterly Jounal of Economics, v.84, n.2, p.488-500, 1970.

${ }^{15}$ STIGLITZ, J.E. Incentives and risk sharing in sharecropping. Review of Economic Studies, v.41, p.219-255, 1974.
} 
risco de preço, e os custos de transação inerentes a operações em futuros, buscar-se-á adiante modelar a interação de ambas as variáveis. Buscar-se-á mostrar que um agente apenas fará uso do hedge, se o benefício dessa operação for maior que seus custos de transação. Com essa demonstração, através do referencial teórico de decisão em ambiente de incerteza, ficará clara a interação entre risco e custos de transação, solidificando a idéia da presente pesquisa sobre a importância da caracterização e mensuração dos custos em mercados futuros.

\subsection{Importância econômica dos custos de transação}

A preocupação da teoria econômica com custos de transação surgiu com as idéias propostas por Coase (1937), em seu artigo seminal The Nature of the Firm, pois até então os economistas desconsideravam tal fenômeno econômico e não tratavam da razão pela qual existiam firmas organizadas ${ }^{16}$. A literatura econômica existente, associada à escola neoclássica, era relativamente omissa quanto à questão da existência de firmas, assumindo em larga medida toda regulação e coordenação do mercado eram dadas através do preço. Ou seja, todas decisões de oferta e demanda eram impostas apenas por este indicador.

Coase (1937) lançou as primeiras idéias de custo de transação ao assumir que as firmas podem organizar-se na busca da redução de custos de informação. $O$ autor reconheceu também que havia custos em negociar e concluir contratos, e que as firmas poderiam utilizar técnicas para reduzir esses custos. Essa nova visão norteou uma corrente de idéias que até os dias de hoje utiliza desses conceitos para a explicação de fenômenos econômicos relacionados, por exemplo, a instituições e organizações (Shelanski \& Klein, 1995).

\footnotetext{
${ }^{16}$ No contexto do artigo de Coase, firmas organizadas são aquelas as quais existe a figura do empresário (empreendedor), que em um sistema competitivo, toma decisões estratégicas no tocante à alocação de recursos da firma. O termo firmas organizadas tem o intuito de se opor ao conceito de que o papel coordenador da alocação de recursos era função somente do mecanismo de preço de mercado.
} 
Vários autores citam o pioneiro trabalho de Coase, mas fazem algumas considerações pertinentes. Williamson (1975) expõe que tal autor tratou apropriadamente os custos de transação, considerando-os como peça central de análise. Todavia, suas proposições eram superficiais a ponto de não permitir uma operacionalização que avaliasse a eficácia de transações entre firmas e mercados, de maneira sistemática. Milgron \& Roberts (1992) também comentam que Coase não foi muito explícito quanto à origem dos custos de transação e que, sem o entendimento sistemático desses aspectos, as idéias têm pouca utilidade. Desta feita, muitas pesquisas foram desenvolvidas sobre economia das organizações para dar corpo às idéias seminais do autor.

No que tange à definição do termo custos de transação, Dorward (2001) cita que há diversas versões na literatura e que ainda não há um consenso. Houthakker (1959) define custos de transação como sendo os "sacrifícios necessários para concluir uma transação (p.145)". Mas Demsetz (1968) expõe que se deve ter cautela em definir tal conceito, pois interpretações muito abrangentes de custos de transação podem levar a problemas empíricos e conceituais extremamente complicados.

Williamson (1985) buscou categorizar custos de transação em contratos, dividindo-os em ex-ante e ex-post. O primeiro está relacionado aos custos de desenho dos contratos e negociação. Já os custos ex-post estão relacionados à má adaptação aos termos do contrato e custos de ajustes que dependem da estrutura de governança, sendo que os dois custos são interdependentes. O autor argumenta que em um contexto mais geral, deve-se analisar o balanço entre custo de produção e transação, pois a soma dos dois é que deve ser minimizada; o contexto social deve ser também considerado (cultura, hábitos etc) quando difere no ambiente analisado, pois isso influencia os custos de transação.

Milgron \& Roberts (1992) também procuram caracterizar custos de transação, argumentando que devem ser encarados como os custos de operar o sistema, causados principalmente pela necessidade de coordenação e motivação. O primeiro está associado com o problema de determinar detalhes da transação e fazer existir um modo em que compradores e vendedores se relacionem e negociem. Já a motivação está associada a 
dois outros fatores, sendo um, relativo aos custos derivados da informação incompleta e assimetria de informação e, outro, relacionado à imperfeição do cumprimento de contratos, em que há oportunismo envolvido.

Por fim, cabe destacar que alguns fatores podem alterar os custos de transação de certas formas organizacionais, alterando os arranjos contratuais vigentes. Dois desses fatores são mudanças relacionadas à tecnologia e ao ambiente institucional. Thompson \& Sonka (1997) estudaram os potenciais efeitos de aprimoramentos tecnológicos na performance de mercados agrícolas. Os autores apontam que mercados futuros parecem estar aprendendo que eles podem promover o uso de seus mercados e aumentar sua liquidez apenas reduzindo barreiras quanto à informação, através da adoção de novas tecnologias como a Internet.

Com relação à mudanças no ambiente institucional, em muitas ocasiões, práticas de mercado sofrem interferência e respondem a várias restrições impostas pelo governo com relação à comercialização. Demsetz (1967) expõe que muitos economistas tomam direitos de propriedade como dados em suas análises e, a partir daí, fazem seus questionamentos. Entretanto, o autor argumenta que o correto é exatamente o oposto, em que, primeiramente, dever-se-ia indagar sobre a emergência e sobre o conjunto de componentes do ambiente institucional, como por exemplo, as leis.

\subsection{Estudos sobre custos de transação aplicados aos mercados futuros}

Diversos livros texto sobre derivativos agropecuários, amplamente utilizados, como os de Hull (1996) e Leuthold et al. (1989), bem como livros brasileiros como o de Marques e Mello (1999), apresentam de maneira muito superficial os custos relativos a operações em mercados futuros. Quando muito falam sobre as taxas pagas às bolsas, informações ínfimas sobre tributações, sem um aprofundamento maior nesses temas. Entretanto, através da revisão de literatura, encontrou-se diversos trabalhos que tratam sobre custos em mercados futuros, analisados das mais diversas formas, buscando mostrar a importância de sua consideração quando da análise de estratégias ligadas a derivativos. 
Howard \& D'Antonio (1994), por exemplo, citam que apesar de alguns trabalhos indicarem que o hedging aumenta o retorno esperado da atividade, os custos dessa operação são de importante consideração. Os autores chegam a afirmar que os hedgers pagam todo o custo à medida que reduzem o retorno esperado no montante dos custos de transação, enquanto recebem menos que o total do benefício, pois não eliminam todo o risco devido ao hedging não ser perfeito. A natureza do problema expressa nessa idéia, é que norteia a presente pesquisa: o benefício do hedging vem a um certo custo, que não pode ser desconsiderado.

Para dar uma demonstração de que a análise dos custos de transação interfere em operações em futuros, Howard \& D'Antonio (1994) desenvolveram um modelo de razão ótima de hedge em que argumentam que devido aos custos dessa operação, os agentes escolheriam uma razão menor do que a ótima, geralmente usada, que ignora os custos. Isso configura, segundo os autores, que os benefícios do hedging tendem a ser menores, pois em geral, os trabalhos não consideram custos de transação e dão como resposta razões de hedge sub-ótimas. Lence (1995) também chama a atenção sobre ignorar algumas variáveis, dentre elas os custos de se operar em bolsa, que podem resultar em análises pouco aderentes à realidade.

Por outro lado, alguns autores consideram os custos de se operar em mercados futuros muito baixos. Harwood et al. (2002), por exemplo, expõem que são modestos frente ao benefício da redução de risco. Ennew et al. (1992), em estudo empírico com agentes do mercado de batata na Inglaterra, relataram que mesmo os indivíduos que já haviam utilizado mercados futuros, não percebiam os custos de mercados futuros como fator importante na decisão de se fazer ou não, uma operação de hedge. Tais percepções divergentes fazem com que o presente trabalho traga contribuições sobre a importância dos custos de transação em operações de hedge. O que se fará, a seguir, é uma exposição sobre alguns trabalhos que tratam sobre diversos custos de se negociar em bolsa.

Um dos trabalhos pioneiros em custos de transação em mercados organizados foi elaborado por Demsetz (1968), em que o autor buscou identificar os principais custos de se operar na Bolsa de Nova Iorque (New York Stock Exchange). Ele argumenta que a existência de poucas bolsas (com altos volumes transacionados) ocorre devido à 
diminuição nos custos de transação obtidos por ganhos de escala de negociação. Além disso, dá atenção particular aos denominados especialistas, os quais são profissionais que operam e dão liquidez ao mercado, explicando que o alto nível de conhecimento dessas pessoas é difícil (ou demorado) de reproduzir em larga escala, limitando o tamanho das bolsas.

Demsetz (1968) considerou que além das taxas pagas às bolsas e corretoras, existiria um segundo custo de transação, associado à necessidade de escala de negociação e de um certo número razoável de especialistas. Se esses fatores não fossem verificados, haveria um alto custo relacionado ao baixo volume negociado, implicando em dificuldades de se entrar e sair desses mercados.

$\mathrm{O}$ autor denominou esse fenômeno como custo de liquidez, buscando analisar em que proporção os custos de transação eram afetados pela escala de negociação no mercado de ações da bolsa de Nova Iorque. Cuny (1993) define liquidez como a habilidade de um mercado absorver risco, sendo dependente do número total de negociantes e da estrutura de mercados similares. De maneira simples, um mercado com liquidez é aquele em que não há dificuldades em se negociar contratos por haver muitos participantes, ou seja, é fácil a compra e a venda de contratos a qualquer momento.

Para tratar do problema de liquidez, Demsetz (1968) utilizou-se do termo ask-bid spread, que é definido pela diferença entre as ofertas de compra e venda feita pelos agentes que operam diretamente no pregão e dão liquidez ao sistema. $\mathrm{O}$ autor argumenta que esses agentes especializados aceitam comprar e vender contratos a qualquer momento, porém, cobram por esse "serviço". Continua afirmando que o ask-bid spread pode ser tratado como um custo de transação por considerar problema do "imediatismo" em oferta e demanda de contratos. Resumidamente, o ask-bid spread, para hedgers, é custo de se transacionar sem atraso. Thompson \& Waller (1987), por exemplo, consideram o conceito de ask-bid spread proposto por Demsetz (1968), um modelo aceitável para se medir liquidez.

Outro custo de transação, relatado na literatura, refere-se à possível barreira à entrada aos agentes de mercado que queiram operar em mercados futuros, relacionados à necessidade de aprendizado (Hirshleifer, 1988). Devido ao alto grau de complexidade 
intrínseca a uma operação em futuros, é necessário um certo período de tempo para que se aprendam os mecanismos necessários a uma boa operação. Isso implica em custos diretos tais como a necessidade de se fazer um curso sobre derivativos, assinatura de revistas especializadas, e até mesmo o custo do tempo que esse empreendedor irá despender nessas atividades extras.

Hieronymus (1977) chama a atenção, por exemplo, para a importância da habilidade em se operar em contratos futuros, e que essa habilidade é fator chave para o sucesso da operação. Segundo ele, falta de habilidade ou o uso incorreto dos mercados futuros é, freqüentemente, a causa principal de falhas das firmas. Uma boa operação em mercados futuros, segundo o autor, requer um talento relativamente raro e difícil de se desenvolver, mostrando implicitamente que existe um custo em capacitar-se nessa nova atividade.

Corroborando a noção de custos de aprendizado, Sonka \& Patrick (1984) afirmam que há evidências de que para pequenos produtores, contratos a termo são mais populares do que operações de hedge porque envolvem, dentre outros fatores, uma menor necessidade de capacitação. Harwood et al. (2002) também confirmam essa opinião, citando que existem resultados empíricos que mostram que grandes produtores operam mais em futuros do que pequenos, justificando esse fato com o argumento de que grandes propriedades podem contratar pessoas especializadas para administrar risco, enquanto pequenos produtores preferem contrato a termo devido aos menores custos.

Como forma de diminuir esse empecilho, Harwood et al. (2002) citam alguns exemplos reais, tanto de governo como das bolsas, com relação ao papel educacional na utilização de instrumentos de administração de risco. Justificam que isso seria uma forma de quebrar essa barreira inicial, através de workshops, programas educacionais, eventos informativos, e pesquisas para educar melhor produtores e entender suas necessidades no processo de aprendizado. Ennew et al. (1992) também destacam a importância do papel educacional feito pelas bolsas, como forma de esclarecer os benefícios e perigos (problemas) inerentes a essas operações. Segundo os autores, isso poderia reduzir os custos de aprendizado aos potenciais usuários hedgers. 
Outro custo transacional verificado está relacionado aos recursos que um agente utiliza durante a operação, entendendo-se por recursos tanto os financeiros, como o tempo do administrador. Sonka \& Patrick (1984) afirmam que para pequenos produtores, da mesma forma que o custo de aprendizado, a necessidade de menor tempo de administração de contratos a termo, os levam a preferir essa modalidade contratual em vez de operações em mercados futuros. Esse fato mostra que em certos casos, os custos de administração podem ser relevantes frente ao benefício percebido.

Contudo, o problema de custos de administração da operação se simplifica no caso de contratação de um profissional especializado. Nesse caso, o custo seria, principalmente, o salário pago a este indivíduo. Cabe ressaltar que essa contratação também pode resultar em custos de transação do tipo monitoramento (Milgrom \& Roberts, 1992), à medida que o dono da empresa ou propriedade teria de acompanhar a atividade desse empregado, a fim de que este busque estratégias que estejam conforme aos objetivos da firma, e não de interesses próprios. Tal modalidade de custo é amplamente tratada na literatura de teoria da agência, mas foge do escopo deste trabalho uma discussão mais extensa. Um exemplo de aplicação é o trabalho de Bibnotto \& Azevedo-Filho (2003).

Um último custo de transação, verificado na revisão de literatura, trata da idéia de custo de oportunidade do capital. Principalmente, os custos associados ao depósito de margem de garantia. Esse ponto de vista é, por exemplo, defendido por Telser (1981). O autor reconhece que o depósito de margem é um fenômeno natural em mercados organizados, ou seja, não advém de pressões governamentais e expressa o desejo de proteção do sistema por parte dos próprios agentes. Mas argumenta que esse mecanismo impõe custos ao usuário de mercados futuros. Telser (1981) chega a afirmar que aumentos no valor a ser depositado podem influenciar negativamente na liquidez das negociações, devido aos agentes perceberem esses custos.

A noção de que a margem impõe custos significativos ao operador de mercado não é consenso entre os economistas, sendo alvo de muito debate (Adrangi \& Chatrath, 1999). Leuthold et al. (1989) e Harwood et al. (2002), por exemplo, consideram o depósito de margem um montante relativamente baixo com relação ao valor total do 
contrato, concluindo que, mesmo se houver um custo, seria de pequena magnitude. Nelson (1985) afirma que o custo de margem em mercados futuros pode ser ignorado sem perda de acurácia, pois seu valor é ínfimo quanto comparado à diminuição do benefício causada pelo risco de base.

Hartzmark (1986), por sua vez, não só acredita que a margem implica em custos, como também considera que mudanças no seu valor alteram a composição dos indivíduos que operam no mercado (por exemplo: proporção entre hedgers e especuladores, empresas de grande e pequeno porte, agentes menos ou mais informados etc). $\mathrm{O}$ autor ainda argumenta que os custos de margem não precisam ser substanciais para causar importantes efeitos no comportamento dos agentes envolvidos.

Apesar de Adrangi \& Chatrath (1999) citarem que não há evidências que comprovem que mudanças na margem alteram a composição dos indivíduos que operam no mercado, eles defendem que há grande clareza quanto à existência de custos significativos de margem, a ponto de desencorajar a entrada de possíveis negociadores em mercados futuros. Tal ponto de vista também é defendido por Baer et al. (1996).

Telser (1981) cita que mesmo depositando como margem títulos que rendam juros, há uma diferença substancial entre títulos depositados como margem e títulos disponíveis para uso. Expondo de outra forma, há custo na alocação de recursos para margem devido ao fato que eles não podem ser usados para outras finalidades (despesas emergenciais ou oportunidades vantajosas).

Seguindo essa linha de raciocínio, Hartzmark (1986) diz, portanto, que a partir do momento do depósito dos títulos como margem, eles têm uma probabilidade positiva de não estarem disponíveis para serem transformados rapidamente em dinheiro, configurando um custo esperado. $\mathrm{O}$ autor reconhece outros custos de transação tais como de recomposição do portfólio (dado que terá de se desfazer de outros ativos para depositar a margem), mas trata, principalmente, da definição do custo de oportunidade. Um exemplo simples desse custo pode ser encontrado no trabalho do autor. 


\subsection{Custos operacionais}

O que motivou essa modalidade de custo transacional ser tratada à parte, é que, ao contrário dos outros custos anteriormente citados, seu cálculo é estabelecido por regras claras, sendo de conhecimento e de fácil compreensão a todos que operam em mercados futuros. Os livros textos costumam trazer como custos operacionais apenas a cobranças de taxas feitas pela bolsa e corretoras (Hull, 1996; Marques \& Mello, 1999). Trabalhos que buscam melhores estratégias em mercados futuros acabam também considerando apenas os custos operacionais (isso quando não desconsideram), como descrito em Lence (1995).

Esses custos têm sua origem devido a tal instrumento de comercialização ter como uma de suas funções, agrupar vendedores e compradores em um mesmo ambiente físico, a fim de facilitar transações. Para que isso aconteça de maneira organizada a bolsa incorre em custos que, por sua vez, são cobertos por taxas pagas pelos agentes de mercado (hedgers e especuladores), proporcionais ao número de contratos negociados. As corretoras de futuro também cobram comissões, pois representam seus clientes perante a bolsa. Segundo Houthakker (1959), essas taxas representam custos de transação na sua forma mais pura.

Conforme explicado por Marques \& Mello (1999), em uma operação de mercados futuros na BM\&F, existem três tipos de custos operacionais envolvidos:

- Taxa Operacional Básica (TOB): é uma taxa definida pela bolsa e consiste em um pagamento de certo percentual do total de contratos negociados, na entrada e na saída da operação. Essa taxa é uma despesa pelos serviços da corretora e é calculada sobre o preço de ajuste do dia anterior do segundo vencimento em aberto.

- Taxa de registro: é um pagamento proporcional ao número de contratos negociados, no início e final da operação

- Emolumentos: utilizados para cobrir custos da bolsa, sendo um percentual da TOB. 
A seguir, na Tabela 4, serão apresentados os custos operacionais de algumas commodities agrícolas negociada na $\mathrm{BM} \& \mathrm{~F}^{17}$, referentes ao dia 20/11/2003, para hedgers ${ }^{18}$.

Tabela 4. Custos operacionais das commodities agrícolas na BM\&F.

\begin{tabular}{cccc}
\hline Contrato & $\begin{array}{c}\text { TOB }(\%) \\
\text { por contrato } \\
\text { negociado }\end{array}$ & $\begin{array}{c}\text { Emolumentos } \\
(\% \text { da TOB })\end{array}$ & $\begin{array}{c}\text { Taxa de Registro por } \\
\text { contrato negociado }\end{array}$ \\
\hline Açúcar & 0,3 & 6,32 & $0,08^{*}$ \\
Álcool Anidro & 0,3 & 6,32 & $0,20^{* *}$ \\
Algodão & 0,3 & 6,32 & $0,08^{*}$ \\
Boi Gordo & 0,3 & 6,32 & $0,20^{* *}$ \\
Bezerro & 0,3 & 6,32 & $0,20^{* *}$ \\
Café Arábica & 0,3 & 6,32 & $0,08^{*}$ \\
Milho & 0,3 & 6,32 & $0,20^{* *}$ \\
Soja & 0,3 & 6,32 & $0,08^{*}$ \\
\hline
\end{tabular}

Fonte: BM\&F (2003)

* em dólar

** em reais

Para exemplificar como é o processo de cobrança dessas taxas, supõe-se que um hedger compre (ou venda) 10 contratos de milho, sendo cada contrato correspondente a 450 sacas de $60 \mathrm{~kg}$, e que o preço de ajuste do dia anterior do segundo vencimento em aberto seja $\mathrm{R} \$ 17,00$ por saca ${ }^{19}$. A esse preço, o valor total do contrato seria de

$10 \times 450 \times \mathrm{R} \$ 17,00=\mathrm{R} \$ 76.500,00$

Assim, para o cálculo da TOB, ter-se-ia o especificado a seguir

$\mathrm{R} \$ 76.500,00 \times 0,003=\mathrm{R} \$ 229,5$

\footnotetext{
${ }^{17}$ Disponível na Internet pelo site: http://www.bmf.com.br

${ }^{18}$ Esses valores são distintos para operadores day trade.

${ }^{19}$ Para melhor entendimento, se um contrato fosse negociado no dia 15 de maio, no caso do café, haveria contratos futuros sendo negociados para: maio, julho, setembro, etc. Pela definição dada, seria considerado como base de cálculo o vencimento de julho (segundo vencimento em aberto) e o seu preço de ajuste negociado em 14 de maio (dia anterior).
} 
O hedger pagaria $\mathrm{R} \$ 229,50$ no início da operação, referente à taxa operacional básica. Da mesma forma, ao final da operação, seria pago outra quantia, que poderia diferir dessa devido à mudança do valor da base de cálculo.

Para o pagamento da taxa de registro, tem-se que para o milho seu valor é de R\$ 0,20 por contrato. Logo, dada a suposição de que foram comprados/vendidos 10 contratos, o valor total cobrado seria de $\mathrm{R} \$ 2,00$.

Por fim, seriam também cobrados os emolumentos, os quais correspondem ao valor de 6,32\% da TOB. Ou seja, $\mathrm{R} \$ 14,50$ no início da operação, e um valor que dependeria do valor da TOB a ser cobrada ao final da operação.

Ao supor que a TOB e emolumentos são iguais na abertura do contrato e no seu fechamento, e sendo a taxa de registro um valor fixo, o total cobrado ao final da operação (somando os pagamentos na entrada e saída) seria de

$$
2 \times(229,50+14,50+2,00)=\mathrm{R} \$ 492,00
$$

Dado o valor total negociado de $\mathrm{R} \$ 76.500,00$, os custos operacionais correspondem a aproximadamente $0,64 \%$ desse valor. Mesmo sendo tais cálculos hipotéticos, tem-se uma idéia da magnitude dos custos operacionais (um exemplo semelhante é apresentado por Marques \& Mello, 1999). Todavia, cabe ressaltar que o valor de emolumentos cobrado pelas corretoras pode ser negociado com o cliente, conforme o volume a ser transacionado ${ }^{20}$.

\subsection{Tributação}

A caracterização da influência da tributação em mercados futuros configura-se em um dos objetivos principais deste trabalho. A inclusão de tributos na análise

\footnotetext{
${ }^{20}$ Essa informação foi obtida em diálogos pessoais com operadores de algumas corretoras credenciadas à BM\&F (consultar Anexo B).
} 
econômica de mercados futuros suscita a importância da estrutura legal na eficiência e tomada de decisão das firmas e indivíduos.

Devido à dificuldade de obtenção das informações dispersas entre os agentes, relativas à forma de incidência de todos os tributos, alíquotas, distinção de cobrança entre pessoa física e jurídica, e demais particularidades, o esforço feito para sua

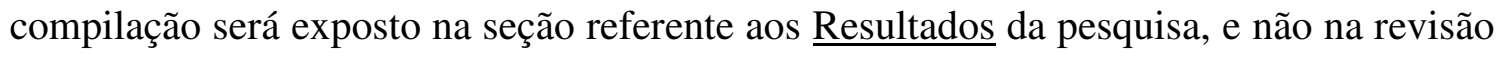
bibliográfica. Isso se justifica ainda mais pelo fato de não existir algo similar apresentado na literatura consultada, nem que seja de conhecimento dos agentes que operam no mercado, nem por pessoas ligadas aos assuntos tributários.

Dessa forma, o que será exposto, por ora, é uma breve descrição sobre a natureza dos tributos incidentes em mercados futuros, para apenas, posteriormente, ser feita sua caracterização quanto à forma de incidência nas operações de hedge. De uma maneira geral, Carvalho (2003) explica que os tributos podem ser classificados em três categorias: taxas, contribuições de melhoria e impostos. Rosa Junior (1995), porém, argumenta que apesar de o Código Tributário Nacional, em seu artigo $5^{\circ}$, prescrever apenas essas três categorias, as contribuições sociais e os empréstimos compulsórios devem ser também considerados como tributos.

Em operações na BM\&F, os tributos a serem pagos pelos agentes de mercado classificam-se em duas modalidades: imposto e contribuição social. Carvalho (2003) distingue os impostos em três tipos: a) impostos que incidem sobre o comercio exterior, atribuídos à União. Ex: imposto de importação (II); b) impostos sobre patrimônio e renda. Ex: imposto sobre renda e proventos de qualquer natureza (IR); c) impostos sobre a transmissão, circulação e produção. Ex: imposto sobre produtos industrializados (IPI). O imposto incidente em operações em mercados futuros é sobre patrimônio e renda, mais especificamente, sobre renda variável.

Com relação às contribuições, Carvalho (2003) expõe que podem ser classificadas em três diferentes espécies: social, interventiva e corporativa. As contribuições sociais, que são as que incidem nas operações em mercados futuros, podem ser divididas em: a) genéricas: voltadas aos diversos setores compreendidos no 
conjunto da ordem social, como educação, habitação etc; b) destinadas ao custeio da seguridade social, compreendendo a saúde, previdência e assistência social.

A tributação em mercados futuros possui algumas peculiaridades quanto à sua cobrança, com diferenças entre pessoa física e jurídica (e até mesmo dentro da própria classificação de pessoa jurídica). Outra distinção se dá quanto ao tipo de operação, em que o presente trabalho irá focar no uso de mercados futuros para hedgers, excluindo a análise de operações day $\operatorname{trade}^{21}$.

Contudo, deve ser feito um esclarecimento oportuno para as futuras explicações. Muitas vezes serão citadas as palavras alíquota e base de cálculo. A primeira nada mais é que o percentual a ser aplicado do tributo. Já a base de cálculo é o montante ao qual será aplicada a alíquota. Por exemplo, pode ser que em um caso a base de cálculo seja o lucro de uma empresa em certo período. Se, porventura, a empresa obtiver prejuízo, a base de cálculo será zero e não incidirá qualquer alíquota. Em caso de lucro, a base de cálculo é o próprio lucro, e a alíquota a ser aplicada será um percentual desse montante.

Nos próximos itens serão feitas breves explicações acerca dos tributos os quais podem incidir nas operações em bolsa de futuros. Muitas das informações podem ser encontradas no site da Secretaria da Receita Federal (SRF), 2003.

\subsubsection{IRPF e IRPJ}

A forma de pagamento do imposto de renda difere entre pessoa física e jurídica. Em se tratando de definição, Diniz (1998) cita que pessoa física (ou pessoa natural) "é todo ser humano considerado como sujeito de direitos e obrigações" (p. 589). Ainda segundo a autora, pessoas jurídicas são "unidades de pessoas naturais ou de patrimônios, que visam à consecução de certos fins, reconhecida pela ordem jurídica como sujeito de direitos e obrigações" (p. 588). Para a análise a ser feita, cabe destacar as pessoas jurídicas de direito privado, que se constituem em associações, sociedades e fundações (Lei 10.406/02, art. 44).

\footnotetext{
${ }^{21}$ A IN da SRF 25/01, art. 31, é que versa sobre a tributação de operações day trade.
} 
No caso de pessoa física que exerça atividade rural (caso de muitos produtores rurais) ${ }^{22}$, obviamente, o IRPF incide não só na operação de hedge, mas também nos ganhos obtidos no mercado físico. A base de cálculo para o imposto, nesse caso, é a diferença entre receitas (advindas, por exemplo, da venda da produção agrícola) e despesas/investimentos (custo com defensivos, compra de tratores etc) incorridos no ano calendário (de janeiro a dezembro). Em caso de lucro nesse período, tal valor será a base de cálculo para o imposto (IN da SRF 83/01, art. 11). Entretanto, se a pessoa física não tiver sua contabilidade apurada através do Livro Caixa ${ }^{23}$, conforme requerido pela SRF, aplica-se uma base de cálculo à razão de $20 \%$ da receita bruta do ano calendário (IN da SRF 83/01, art.22, § 2 ). Dada a base de cálculo, para ambos os casos (com ou na ausência de Livro Caixa), a pessoa física será tributada conforme a os dados da Tabela 5 $5^{24}$

Tabela 5. Tabela progressiva para cálculo anual do imposto de renda de pessoa física para o exercício de 2003, ano-calendário de 2002.

\begin{tabular}{cc}
\hline Base de cálculo anual, em R\$ & Alíquota \% \\
\hline Até $12.696,00$ & - \\
De $12.696,01$ até $25.380,00$ & 15,0 \\
Acima de $25.380,00$ & 27,5 \\
\hline
\end{tabular}

Fonte: SRF (2003)

Resumindo: se a pessoa física que exerça atividade rural possuir o Livro Caixa, toma-se a receita, deduzidas as despesas/investimentos dos meses do ano, e esse valor é que vai pra tabela de tributação da pessoa física. Dessa forma, se não tiver lucro no ano,

${ }^{22}$ A classificação das pessoas físicas que exercem atividade rural pode ser encontrada na IN da SRF 83/01, art. 2.

${ }^{23}$ O Livro Caixa é uma escrituração ordenada e sistemática dos fatos contábeis realizados pela pessoa física que exerce qualquer atividade comercial, facultativo ao comerciante adotá-lo ou não. Devem ser escrituradas as receitas e despesas advindas do exercício da atividade para que haja condição legal de utilizar desses valores no cálculo da Declaração Anual de Imposto de Renda (Diniz, 1998).

${ }^{24}$ Cabe ressaltar que a cobrança do IRPF é progressiva, ou seja, no caso de uma pessoa que a base de cálculo é de trinta mil reais, a alíquota de 27,5\% é aplicada apenas ao valor que exceder o valor de $\mathrm{R} \$ 25.380,00$, e o restante pelas alíquotas correspondentes às faixas de base de cálculo. 
não paga imposto. Na ausência do Livro Caixa, presume-se um lucro correspondente a $20 \%$ da receita anual, sendo essa a base de cálculo para o IRPF, mesmo quando não houver lucro. É importante deixar claro que para pessoa física, os ganhos obtidos em mercados futuros não fazem parte da receita a ser tributada ao final do ano calendário, porque sua tributação é na fonte.

Com relação ao imposto de renda da pessoa jurídica (IRPJ), torna-se um assunto um pouco mais complexo. Melo (1997) expõe que a base de cálculo do imposto de renda para pessoas jurídicas pode ser o lucro real, arbitrado ou presumido, de renda ou proventos tributáveis. Latorraca (1981) explica que o lucro real será determinado a partir do lucro líquido em balanço patrimonial, sendo feito alguns ajustes, pois o lucro real tributável não é exatamente igual ao lucro contábil. A apuração, geralmente, é feita de forma trimestral, podendo, por opção do contribuinte, ser mensal. Porém, este último caso é menos comum (consultar Anexo A).

Já o lucro presumido, segundo Latorraca (1981), é faculdade privativa das firmas individuais e sociedades por quotas de responsabilidade limitada ou em nome coletivo, até uma certa receita bruta ${ }^{25}$. Melo (1997) cita que são geralmente empresas de pequeno porte em que se aplica um específico percentual sobre a receita bruta auferida na atividade. Por fim, Latorraca (1981), explica que o lucro arbitrado pelo fisco é aplicável aos casos em que a pessoa jurídica não mantém escrituração contábil ou a mantém de forma irregular. Melo (1997) complementa dizendo que se desconhecido, o lucro é determinado mediante a utilização de coeficientes, segundo regras específicas. Em ambas as opções é comum a apuração ser feita trimestralmente. A alíquota é de $15 \%$ para os dois casos, sendo a base de cálculo de 8,0\% e 9,6\% da receita bruta para os casos de apuração pelo lucro presumido e arbitrado, respectivamente.

\footnotetext{
${ }^{25}$ Esse valor, atualmente, é um mínimo de receita bruta de $\mathrm{R} \$ 48.000 .000,00$ anual.
} 


\subsubsection{CSLL}

A Contribuição Social sobre Lucro Líquido (CSLL) destina-se ao financiamento da seguridade social (Lei 7.689/88, art. 1º), e é cobrada somente das pessoas jurídicas. Segundo Melo (1997), para o caso da tributação pelo lucro real, tal contribuição poderia ser vislumbrada como uma figura assemelhada ou equiparada ao IRPJ, ou até mesmo como um adicional deste, em razão de vislumbrar a mesma base de cálculo (resultado positivo tomado ao final de um determinado período de tempo). Porém, continua o autor, no imposto de renda a base de cálculo é o lucro contábil, feita algumas adições e subtrações. No caso da CSLL, a base de cálculo é exatamente o lucro contábil. Portanto, o valor que se apura para essa contribuição pode ser diferente do valor apurável para fins de imposto de renda (lucro real, presumido ou arbitrado).

No caso de empresas tributadas com base no lucro presumido ou arbitrado, a base de cálculo do IRPJ e da CSLL, são exatamente as mesmas (a receita bruta). Uma observação importante é que, quando a empresa optar por ser tributada pelo lucro real, presumido ou arbitrado, tanto o IRPJ quanto a CSLL deverão seguir a mesma forma de apuração.

Segundo informações do site da Receita Federal, as pessoas jurídicas tributadas pelo lucro real trimestral deverão apurar a CSLL trimestralmente, à alíquota de 9\%. As pessoas jurídicas tributadas pelo lucro arbitrado ou presumido, devem apurar e pagar a CSLL, também pelo período de três meses. A base de cálculo nesses casos será o percentual $12 \%$ da receita bruta auferida no período, sendo a alíquota 9\% (MP n ${ }^{\circ} 1.859$ 10, de 1999, e reedições; MP 1.991-12, de 1999, art. $6^{\circ}$, II, e reedições).

\subsubsection{Pis/Pasep e Cofins}

A Contribuição para o Financiamento da Seguridade Social (Cofins) incide sobre o faturamento mensal, que corresponde à receita bruta da pessoa jurídica, sendo irrelevante a classificação contábil adotada para essas receitas (lucro real, presumido ou arbitrado). Já a cobrança da Contribuição para o Programa de Integração Social e para o Programa de Patrimônio do Servidor Público (Pis/Pasep), divide-se em duas modalidades: sobre o faturamento e sobre a folha de salários. 
Sobre o faturamento, situação que interessa para fins de tributação em mercados futuros, a base de cálculo é o faturamento mensal, cobrada somente de pessoa jurídica, sendo a mesma base de cálculo que a Cofins (informações do site da SRF). Dessa forma, para efeito de análise de sua incidência em mercados futuros, ambas as contribuições podem ser tratadas como uma só.

Segundo Melo (1997), não existe bitributação de Pis/Pasep e Cofins, pois incidem sobre a mesma base de cálculo (faturamento). A alíquota da Cofins é de 3\% para todas as pessoas jurídicas. Já o percentual cobrado de Pis/Pasep é de 1,65\% para empresas que são tributadas pelo lucro real, e $0,65 \%$ daquelas que optam pelo lucro presumido ou arbitrado (Lei $\mathrm{n}^{\circ} 10.637$, de 30 de dezembro de 2002). O recolhimento do Pis/Pasep e da Cofins deverá ser efetuado até o último dia útil da primeira quinzena do mês seguinte ao mês de ocorrência dos fatos geradores da tributação.

\subsubsection{CPMF}

A Contribuição Provisória sobre Movimentação ou Transmissão de Valores e Créditos e Direitos de Natureza Financeira (CPMF), incide sobre a "movimentação ou transmissão de valores e de créditos e direitos de qualquer natureza financeira, sendo essa considerada qualquer operação liquidada ou lançamento, realizado pelas entidades financeiras, que represente circulação escritural ou física de moeda e de que resulte ou não transferência da titularidade dos mesmos valores, créditos e direitos" (Lei 9311/96). Segundo informação do site da SRF, na data da consulta (02/07/2003), tal contribuição será cobrada até 31 de dezembro de 2004, às alíquotas de $0.38 \%$ nos exercícios de 2002 e 2003 , e de $0.08 \%$ no exercício financeiro de 2004. 


\subsection{Modelagem da influência dos custos de transação em tomadas de decisão ${ }^{26}$}

Nesta parte do trabalho serão apresentados conceitos fundamentados, predominantemente, na teoria de decisão em ambiente de incerteza, mais especificamente, no paradigma da esperança da utilidade. O objetivo é demonstrar, através da teoria de decisão fundamentada nesse paradigma, a interação entre administração de risco e custos de transação, e a influência desses dois fatores na escolha de um indivíduo quanto a fazer, ou não, uma operação em mercados futuros. Apesar de o objetivo do trabalho ser apenas a determinação de custos de transação nas operações em bolsa, a apresentação de tal referencial teórico demonstra como os custos de transação podem ser entendidos em um contexto mais global, justificando sua análise.

Seguindo a apresentação do paradigma da esperança da utilidade desenvolvida por Huang \& Litzenberger (1988), tem-se que para duas decisões $D x_{1}$ e $D x_{2}, D x_{1}$ será preferida a $D x_{2}$ se: a esperança da utilidade do resultado obtido $\operatorname{com} x_{1}$ for maior que a esperança da utilidade do resultado obtido $\operatorname{com} x_{2}$. Isso pode ser representado por

$$
E\left[U\left(x_{1}\right)\right]>E\left[U\left(x_{2}\right)\right]
$$

Aplicando-se tais conceitos aos mercados futuros, dada a decisão de um agente que tem a opção de operar nesse mercado, deseja-se saber se ele atingiria um grau de satisfação maior caso operasse em bolsa. Para isso, serão, a seguir, modeladas situações em que se fará a comparação entre dois cenários propostos, tomando-se como exemplo um produtor rural que deve decidir entre operar, ou não, em mercados futuros. Contudo, tal análise pode ser estendida para qualquer agente de mercado.

Para introduzir as noções gerais do modelo a ser construído, será formulada uma situação extremamente simplificada. Tem-se, como exemplo, o caso de um produtor rural que não incorra em riscos quanto à quantidade a ser colhida em data futura, ou seja,

\footnotetext{
${ }^{26}$ Esta seção contou com fundamental colaboração do Prof. Adriano J. B. V. Azevedo-Filho (consultar Anexo B).
} 
isolar-se-á apenas o efeito do risco de preço. Além disso, assume-se que toda a receita desse indivíduo advém somente da venda de uma única commodity.

Portanto, a receita do produtor pode ser expressa por

$$
R=P \cdot Q^{o}
$$

em que:

$R=$ receita do produtor no momento da venda

$P=$ preço futuro do produto, negociado no momento da venda (incerto)

$Q^{o}=$ quantidade a ser colhida, dada como fixa (sem risco) ${ }^{27}$

A receita futura $(R)$ do produtor, nesse caso, pode variar somente em função do preço (P). Logo, pode-se modelar tal situação, através do conceito de esperança da utilidade, da seguinte forma:

$$
E[U(R)]=E\left[U\left(P Q^{o}\right)\right]
$$

que significa que a esperança da utilidade depende da distribuição de probabilidade do preço $(\mathrm{P})$, que nesse caso é uma variável aleatória.

Em outro cenário, considera-se que o produtor assume uma posição em mercados futuros. Nesse caso, ainda mantém-se a hipótese de não haver risco de produtividade, mas é feita uma operação de hedge perfeito, sem custos de transação, e em igual quantidade à produção a ser colhida, eliminando-se totalmente o risco de preço. Logo, tem-se uma receita $R$ com certeza, dada pela multiplicação da quantidade colhida e o preço do produto (ambos sem incerteza).

\footnotetext{
${ }^{27}$ Cabe ressaltar que, em geral, a produtividade também se configura como uma variável aleatória. Porém, a inserção dessa característica apenas traria complicações adicionais que não se justificam, face ao que está se buscando demonstrar. O que se pode argumentar, para a consideração da produção como fixa $\left(Q^{o}\right)$, é que o produtor, ao fazer o hedge, já está com o produto colhido e armazenado, tendo um risco de produtividade pequeno. Ou também se pode supor que o indivíduo possui um seguro de produção, garantindo-a em certo nível.
} 


$$
E[U(R)]=E\left[U\left(P_{f}^{o} Q^{o}\right)\right]
$$

em que:

$$
P_{f}^{o}=\text { preço futuro negociado em bolsa (fixo), ao iniciar a operação }
$$

Através do uso da desigualdade de Jensen (para maiores detalhes, consultar Mood et al., 1963), e sendo a função utilidade estritamente côncava (Ingersoll, 1987), refletindo a pressuposição de utilidades marginais decrescentes, pode-se afirmar que, aceitas as pressuposições sobre preço e produtividade, verifica-se a desigualdade a seguir

$$
E\left[U\left(P_{f}^{o} Q^{o}\right)\right]>E\left[U\left(P Q^{o}\right)\right]
$$

Em termos econômicos, essa desigualdade significa que a situação sem risco (com hedge perfeito e sem incerteza de produtividade) será sempre superior à situação em que há risco. Isto é, a situação em que se faz o hedge será sempre preferível à alternativa de incorrer em risco de preço.

Todavia, argumenta-se que ao operar em mercados futuros, o produtor incorre em custos de transação. Então, pode-se formular essa nova situação de modo que se tenha a seguinte esperança da utilidade

$$
E[U(R)]=E\left[U\left(P_{f}^{o} Q^{o}-C T\right)\right]
$$

em que

$$
\mathrm{CT}=\text { custos de transação }
$$

Utilizando-se das expressões (6) e (9), e fundamentado pela teoria de decisão, chega-se à conclusão que o hedge será utilizado caso a relação a seguir se estabeleça 


$$
E\left[U\left(P_{f}^{o} Q^{o}-C T\right)\right]>E\left[U\left(P Q^{o}\right)\right]
$$

em que a esperança da utilidade de se fazer uma operação em bolsa deve ser maior do que não se fazer.

Com base na desigualdade descrita em (10), pode-se criar uma nova variável que meça o benefício da utilização da operação em futuros, que será chamada de $B H$ (benefício do hedge).

$$
E\left[U\left(P_{f}^{o} Q^{o}-C T+B H\right)\right]=E\left[U\left(P Q^{o}\right)\right]
$$

ou seja, $B H$ é o valor numérico que torna a expressão (10) uma igualdade.

Portanto, o que se busca demonstrar é que sempre existirá um valor do custo de transação $(C T)$ que elimine o benefício do hedge $(B H)$. De modo mais formal, dado o benefício do hedge $(B H)$, haverá sempre um valor de $C T$ que faça com que as duas situações (com ou sem hedge) sejam indiferentes. Qualquer valor de $C T$ acima desse limite faria da opção de não operar em mercados futuros, mais atrativa. Utilizando-se da expressão (11), o limite do custo de transação que elimina todo o benefício, pode ser expresso por

$$
B H-C T=0
$$

O modelo apresentado é baseado no referencial teórico de decisão em ambiente de incerteza, e mostra a importância do objetivo do presente trabalho: a análise dos custos de transação em mercados futuros, como forma de ser uma possível explicação da não participação de certos agentes nesse mercado. O que será feito, a seguir, é uma proposta de sistematização e de mensuração dos custos de transação, mais especificamente, aqueles associados à tributação, margem de garantia, ajustes diários e taxas operacionais, além de demonstrar as diferenças desses custos conforme ao grau de 
capitalização de um indivíduo e do número de dias da operação. O cálculo desses valores será feito através de preços historicamente observados e de técnicas de simulação, assunto esse a ser discutido no próximo capítulo. 


\section{METODOLOGIA}

Como forma de apresentar a metodologia utilizada para obtenção dos resultados desta pesquisa, o presente capítulo será divido em duas partes. A primeira refere-se ao modo de obtenção das informações, que culminaram em duas propostas de sistematização de conceitos (item 4.1). A segunda apresenta a metodologia utilizada para o cálculo dos custos de transação de operações em mercados futuros (item 4.2).

\subsection{Obtenção das informações sobre custos de transação}

Para chegar às propostas de sistematização, a serem exploradas em capítulo posterior, inicialmente foi feita uma revisão de literatura em que se buscou identificar os potenciais custos relatados. Em seguida, foram realizadas conversas informais com pessoas ligadas ao mercado ${ }^{28}$ para a verificação da relevância do material pesquisado, sua adaptação ao mercado brasileiro e identificação de outros possíveis custos. Por último, com os conhecimentos obtidos ${ }^{29}$, buscou-se dar um tratamento formal aos resultados através de uma sistematização consistente (Quadro1).

\footnotetext{
28 Agradecimentos, em especial, a F. Schouchana, L. Vainzof, M. Silva, E. Bignotto e E. Ribeiro (consultar Anexo B).

${ }^{29} \mathrm{O}$ resultado final dessa análise teve intensa colaboração do Prof. A. Azevedo-Filho (consultar Anexo B).
} 
Como conseqüência das entrevistas realizadas com agentes de mercado, o que se verificou foi a existência de um custo de transação, em especial, que não figurava até então dentre os encontrados na revisão de literatura: custos relativos à tributação. Desse fato, surgiu a necessidade de uma segunda proposta de sistematização, relativa aos tributos incidentes em mercados futuros, pois não se havia a clara noção de como eles influenciavam as operações em bolsa de futuros.

A metodologia para a obtenção dos resultados detalhados sobre a tributação (apresentados de forma resumida no Quadro 2), caracterizou-se por entrevistas com agentes de mercado ${ }^{30}$, que forneceram informações fundamentais sobre a sistemática da tributação em operações com derivativos. Porém, muito do entendimento sobre esse assunto apenas foi conseguido com o auxílio de um profissional ligado à área tributária $^{31}$, que esclareceu as dúvidas pendentes sobre os modos de cobrança, sugeriu referências bibliográficas e efetuou correções durante a formulação da proposta de sistematização. Esse aprendizado culminou na percepção de que o real processo de tributação em mercados futuros era algo muito mais complexo do que o conhecimento obtido com os agentes de mercado.

\subsection{Metodologia para mensuração dos custos de transação ${ }^{32}$}

Este trabalho tem como um de seus objetivos, estudar os impactos dos custos de transação nas operações em mercados futuros, em especial aqueles relativos aos ajustes diários, margem de garantia, tributação e taxas operacionais. Como estes custos dependem da trajetória dos preços e/ou do período compreendido entre o começo e o final da operação, serão expostos alguns procedimentos metodológicos que busquem capturar a essência de seus comportamentos.

\footnotetext{
${ }^{30}$ Essa parte teve colaboração fundamental de F. Schouchana e M. Silva (consultar Anexo B).

${ }^{31}$ Agradecimentos ao J. Andrade que, mesmo tendo um conhecimento restrito sobre a área de derivativos, teve incomensurável colaboração nesta parte do trabalho.

32 Esta seção baseia-se fortemente no trabalho desenvolvido por A. Azevedo-Filho e o autor desta dissertação (Azevedo-Filho \& Andrade, 2003), que deve ser consultado para mais detalhes específicos não incluídos neste texto.
} 
Para o cálculo dos custos de transação, foram utilizados 3 métodos distintos e complementares, aplicados ao mercado futuro do milho, sendo que cada um deles traz informações adicionais que auxiliam na melhor compreensão da natureza do problema. O primeiro modelo é baseado em séries históricas de preços futuros de milho, transacionados na BM\&F, em que os custos foram calculados para quatro vencimentos distintos. O segundo método é fundamentado em modelos mais sofisticados (ARIMAGARCH), que proporcionam uma simulação que captura aspectos relevantes das trajetórias de preços observadas, relativas aos quatro vencimentos analisados. Por último, foi aplicado um modelo teórico simplificado que simula preços com base apenas na volatilidade e no número de dias da operação, mas que apesar de limitado por pressuposições fortes, proporciona entendimentos que os outros métodos não são capazes de oferecer. Os processos de cálculo computacional foram implementados no Software R, versão 1.7.1 e no software Ox-G@ rch 3.0.

\subsubsection{Definição dos custos}

Antes da apresentação dos modelos propriamente ditos, serão definidos os custos de transação incorridos nas operações em mercados futuros, que serão medidos pelos três métodos citados. São eles, os custos associados a: tributos, margem de garantia, ajustes diários e taxas operacionais. O que se buscará demonstrar é a dependência desses custos quanto à duração do contrato e, principalmente, quanto à trajetória dos preços. Para possibilitar a mensuração dos custos de transação através dos diversos métodos, será feita, a seguir, sua caracterização formal.

A análise assume que o tempo é medido em dias de operação e que o agente econômico a inicia no período 0 , adquirindo um contrato futuro que irá liquidar no período $m$. $\mathrm{O}$ resultado final dessa operação pode ser representado por

$$
R=A-\mathrm{CT}\left(P_{0}^{f}, P_{1}^{f}, \cdots, P_{m}^{f}, \vec{K}\right)
$$


em que $A$ é o valor do ajuste acumulado (que pode ser um valor positivo ou negativo, dependendo da trajetória dos preços), definido por $P_{0}^{f}-P_{m}^{f}$ no caso de uma operação de venda de contratos futuros, ou por $P_{m}^{f}-P_{0}^{f}$ para o caso da compra de contratos; $\mathrm{CT}\left(P_{0}^{f}, P_{1}^{f}, \cdots, P_{m}^{f}, \vec{K}\right)$ define os custos de transação das operações, sendo dependente da trajetória dos preços e de um vetor $\vec{K}$, que são os parâmetros que caracterizam os valores dos custos de transação, assumidos como conhecidos no início da operação.

Cabe ressaltar uma simplificação muito útil a ser feita. Os preços futuros (de $P_{0}^{f}$ a $P_{m}^{f}$ ) utilizados refletem o valor total do contrato, e não o preço unitário da commodity considerada. Essa notação visa facilitar a análise, dado que alguns custos são especificados por contrato (o valor da margem de garantia e as taxas operacionais, por exemplo, são proporcionais ao volume de contratos negociados). Tal fato possibilitará a apresentação dos custos em bases percentuais relativas ao valor do contrato, tornando mais simples a comparação entre eles.

Alguns dos parâmetros a serem definidos podem ser incertos (ex: taxas de juros), alterando-se ao longo da operação, mas serão considerados fixos para efeito deste trabalho. A incerteza com relação ao valor desses custos vem do não conhecimento, $a$ priori, da trajetória que o preço futuro seguirá entre os períodos de 0 a $\mathrm{m}$. Cada trajetória define um único custo, o que implica que o custo total é uma função da trajetória dos preços compreendida entre o período da operação.

Para fins desta pesquisa, serão considerados 5 tipos de custo (parâmetros $\vec{K}$ ) : (a) taxas operacionais (taxa de registro, taxa operacional básica e emolumentos); (b) pagamentos de IRPF; (c) pagamentos de CPMF; (d) encargos financeiros referentes à margem de garantia; e, (e) encargos financeiros associados aos ajustes diários. A situação modelada é a de um agente do tipo pessoa física.

O modo de incidência e os valores percentuais das taxas operacionais estão descritos na seção 3.4. Sabendo-se que incidem, tanto no início quanto no final da operação, o custo da primeira cobrança é conhecido, mas o valor cobrado ao final 
dependerá do preço no momento $m$. Logo, tem-se um componente de incerteza quanto ao valor desse custo ${ }^{33}$.

Os cálculos referentes à tributação serão aplicados para o caso de pessoas físicas (a cobrança para os diferentes tipos de agentes estão descritos no Quadro1), em que os dois tributos considerados são a CPMF e o IRPF, descritos na seção 3.5. Uma simplificação feita neste trabalho é que o IRPF, que na realidade deve ser pago no $15^{\circ}$ dia útil após o final do mês da apuração do tributo, será simulado como sendo pago ao final do mês dentro qual ele é devido. Testes preliminares mostraram que essa simplificação não alterou significativamente os valores dos custos. Outra peculiaridade, é que as datas correspondentes ao final dos meses, quando o IRPF é calculado, são definidas como ocorrendo a cada 22 dias úteis de operação.

Os custos relativos à margem de garantia e ajustes diários serão, neste momento, melhor explicitados. Essas duas peculiaridades de transações em mercados futuros possuem uma característica em comum: necessidade de capital. Isso porque um agente que deseje operar em mercados futuros deverá ter: recursos financeiros para depósito de margem de garantia, e outro montante reservado para possíveis ajustes diários negativos que ocorram durante a operação. Portanto, esses custos possuem relação íntima com o grau de capitalização do agente.

Considere-se um agente tipo 1 (essa denominação será utilizada daqui por diante) que é amplamente capitalizado, ou seja, possui um volume amplo de recursos financeiros. No caso de sucessivos pagamentos de ajustes, o agente tipo 1 arcará com um custo de oportunidade, pois não poderá aplicar o montante gasto, em outras alternativas. Por outro lado, caso ele deposite a margem de garantia em títulos, que remunerem exatamente à taxa de seu custo de oportunidade, isso não se configurará em custo algum.

\footnotetext{
${ }^{33}$ Uma simplificação utilizada é que o valor base para cálculo das taxas operacionais é definido como sendo o preço futuro do início da operação, no mesmo vencimento analisado. Portanto, o cálculo não será feito sobre o preço futuro do dia anterior, relativo ao segundo vencimento em aberto, como realmente ocorre.
} 
Se em uma outra situação extrema existir um agente totalmente descapitalizado, e se ele operar em mercados futuros, deverá captar dinheiro no mercado (a uma certa taxa de juros) para honrar os compromissos de depósito de margem e, quando for o caso, efetuar o pagamento de ajustes diários. Para esse indivíduo, chamado de agente tipo 2, o pagamento de juros referentes ao dinheiro emprestado, dependerá, no caso do depósito da margem de garantia, do período da operação (quanto maior o período de empréstimo, mais juros serão pagos). Quanto aos custos associados aos possíveis pagamentos de ajustes diários, terão grande dependência da trajetória de preços (no caso de apenas receber ajustes positivos durante o contrato, não teria de captar dinheiro no mercado, configurando-se em um custo de ajuste igual a zero).

Para formalizar os custos financeiros associados à margem e à necessidade de pagamento de ajustes diários, assume-se que um operador do mercado tem pela frente duas taxas de juros relevantes: (a) uma taxa $J_{a}$ que remunera suas aplicações, refletindo o custo de oportunidade do seu capital, pressuposta como sendo a taxa média de remuneração de CDBs; e (b) uma taxa $J_{c}$ para captação de recursos. A idéia geral do modelo apresentado é que o agente recebe juros $J_{a}$ pelos saldos positivos de uma conta que reflete a operação, e paga juros $J_{c}$ pelos saldos negativos

Para agentes tipo 1 (capitalizados), o custo de oportunidade para captação será considerado igual à taxa para aplicações $J_{c}=J_{a}$. Para agentes tipo 2 (descapitalizados), por outro lado, assume-se que terão que recorrer a mecanismos de financiamento para manutenção de suas operações na bolsa. Para esses últimos, a taxa de captação será considerada como sendo $J_{c}$, em que no mundo real, a situação mais usual para esses casos é que a desigualdade $J_{c}>J_{a}$ se verifique.

Os custos associados à margem de garantia dependem de um valor fixo requerido por contrato. Esse valor pode aumentar por chamadas de margem feitas durante a operação, em condições especificas do mercado (não será considerada essa possibilidade). Para o contrato de milho, por exemplo, que corresponde a 450 sacas de $60 \mathrm{~kg}$, o valor da margem para hedgers era $\mathrm{R} \$ 560,00$, em 30 de outubro de 2003, o que representava de $5,6 \%$ a $6,5 \%$ do valor dos contratos nessa data. Uma característica 
importante é que a margem pode ser depositada em certificados de depósito bancário (CDBs) e por outros ativos. Isso implicará em uma redução do custo de oportunidade do dinheiro destinado a esse fim.

\subsubsection{Formalização dos custos de transação}

Para modelar o fluxo de caixa de operações em mercados futuros, serão consideradas 2 contas, representadas por $R$ e $A$. A conta $R$ contabiliza todos os fluxos monetários que realmente se verificam nas operações em bolsa. Nesta conta são creditados e/ou debitados: (a) operações associadas à margem de garantia; (b) taxas operacionais; (c) ajustes diários; (d) tributos; e, (e) encargos financeiros. Quando o saldo é positivo em um dado dia, no dia seguinte são creditados, na conta $R$, os juros obtidos pela aplicação da taxa $J_{a}$ sobre esse saldo. Por outro lado, se o saldo é negativo em certo dia, no dia seguinte serão debitados os juros, à taxa $J_{c}$, sobre esse saldo. Para agentes capitalizados, com capacidade própria de financiamento de suas operações, assume-se $J_{c}=J_{a}$, aplicando-se a mesma regra.

A conta $A$, por sua vez, contabiliza somente o fluxo financeiro dos ajustes diários, desconsiderando pagamento ou recebimento de juros associados a saldos negativos ou positivos, pagamento de tributos, taxas operacionais ou depósito de margem. Essas duas contas são criadas para poderem ser comparadas: na ausência de custos de transação e recebimento de juros, o saldo da conta $R$ será exatamente o resultado da conta $A$.

O interessante desse tipo de abordagem é que se isola a análise apenas para a operação em mercados futuros. Isso faz com que os resultados obtidos digam respeito apenas à operação em bolsa, desconsiderando se o agente fez essa operação por motivo de especulação, ou se é um típico hedger. Além disso, a aplicação dos conceitos a serem expostos é muito ampla, não se resumindo apenas a operações com commodities agrícolas, mas pode ser usada para estudar custos de transação em qualquer transação com derivativos. 
Formalizando tal argumentação, representa-se por $S_{m}^{A}$ o saldo existente na conta $A$, ao final do período $m$, para o caso de uma operação de venda de contratos futuros, resultando que

$$
S_{m}^{A}=P_{m}^{f}-P_{0}^{f}
$$

ou seja, $S_{m}^{A}$ representa o saldo líquido dos ajustes ao final da operação.

Mas dado que o saldo real deve levar em consideração a existência de custos de transação $(C T)$, essa situação pode ser formulada pelo saldo da conta $R$, de modo que

$$
S_{m}^{R}=\left(P_{m}^{f}-P_{0}^{f}\right)-\mathrm{CT}
$$

em que $C T$ representa todos os possíveis custos existentes nas operações em mercados futuros, dentre eles os associados à margem, ajustes, tributação e taxas operacionais.

Utilizando-se das expressões (14) e (15) pode-se definir os custos de transação como sendo

$$
\mathrm{CT}=S_{m}^{A}-S_{m}^{R}
$$

ou seja, a diferença entre os saldos das contas $A$ e $R$.

Se os custos considerados fossem nulos, os saldos finais dessas contas seriam iguais. Em geral, como esses custos existem, a conta $R$ apresentará, em geral, saldo final menor que o existente na conta $A$. Uma medida de custo mais fácil de ser entendida, pode ser obtida pela sua definição como um percentual de $P_{0}^{f}$, o preço inicial fixado. Dessa forma, tem-se

$$
\mathrm{CT}_{\%}=\frac{S_{m}^{A}-S_{m}^{R}}{P_{0}^{f}} \times 100
$$


O que se pode notar é que $C T$ é uma variável aleatória dependente das trajetórias de preços consideradas no período $m$ de operação.

Os custos de transação $(C T)$ podem ser decompostos, do ponto de vista contábil, em seus diferentes componentes: juros nominais recebidos durante a operação, quando o saldo da conta $R$ for positivo $(J R)$; juros nominais pagos, em caso de saldos negativos na conta da operação $(J P)$; taxas operacionais $(T O), I R P F, C P M F$, ajustes $(A)$, compra do certificado $\left(C D B_{0}\right)$ e venda do certificado $\left(C D B_{m}\right)$. Com relação a estes dois últimos componentes, o que se assume é que o agente que operar em mercados futuros comprará um $C D B$ no período que iniciar a operação, em valor tal que faça frente à obrigação do depósito de margem de garantia. E, ao final da operação, no dia $m$, venderá o $C D B$ e resgatará o dinheiro.

Para um melhor entendimento do processo de decomposição dos custos em seus vários componentes, é apresentada, a seguir, a evolução do saldo da conta $R$, em cada período, pelas equações

$$
\begin{aligned}
& S_{0}^{R}=-\mathrm{CDB}_{0}-\mathrm{TO}_{0} \\
& S_{1}^{R}=S_{0}^{R}+\mathrm{A}_{1}+\mathrm{JR}_{1}-\mathrm{JP}_{1}-\mathrm{IRPF}_{1}-\mathrm{CPMF}_{1} \\
& \vdots \\
& S_{m-1}^{R}=S_{m-2}^{R}+\mathrm{A}_{\mathrm{m}-1}+\mathrm{JR}_{\mathrm{m}-1}-\mathrm{JP}_{\mathrm{m}-1}-\mathrm{IRPF}_{\mathrm{m}-1}-\mathrm{CPMF}_{\mathrm{m}-1} \\
& S_{m}^{R}=S_{m-1}^{R}+\mathrm{A}_{\mathrm{m}}-\mathrm{TO}_{\mathrm{m}}+\mathrm{JR}_{\mathrm{m}}-\mathrm{JP}_{\mathrm{m}}-\mathrm{IRPF}_{\mathrm{m}}-\mathrm{CPMF}_{\mathrm{m}}+\mathrm{CDB}_{\mathrm{m}}
\end{aligned}
$$

Para simplificar o modelo, assume-se que a primeira $C P M F$ é paga no período 1 da operação e o último no próprio período $m$. A soma das expressões em (18) resulta em

$$
S_{m}^{R}=-\mathrm{CDB}_{0}+\mathrm{CDB}_{\mathrm{m}}-\mathrm{TO}_{0}-\mathrm{TO}_{\mathrm{m}}+\sum_{t=1}^{m}\left(\mathrm{~A}_{\mathrm{t}}+\mathrm{JR}_{\mathrm{t}}-\mathrm{JP}_{\mathrm{t}}-\mathrm{IRPF}_{\mathrm{t}}-\mathrm{CPMF}_{\mathrm{t}}\right)
$$


No caso da conta $A$, o saldo no período $m$ seria definido simplesmente por

$$
S_{m}^{A}=\sum_{t=1}^{m} \mathrm{~A}_{\mathrm{t}}
$$

Juntando as expressões (16), (19) e (20), chega-se à definição de $C T$ a partir de seus componentes, dada por

$$
\mathrm{CT}=\mathrm{CDB}_{0}-\mathrm{CDB}_{\mathrm{m}}+\mathrm{TO}_{0}+\mathrm{TO}_{\mathrm{m}}-\sum_{t=1}^{m} \mathrm{JR}_{\mathrm{t}}+\sum_{t=1}^{m} \mathrm{JP}_{\mathrm{t}}+\sum_{t=1}^{m} \mathrm{IRPF}_{\mathrm{t}}+\sum_{t=1}^{m} \mathrm{CPMF}_{\mathrm{t}}
$$

Para uma melhor caracterização de $C T$, serão feitas algumas manipulações na expressão acima. Associado à aquisição do $C D B$ para cobertura da margem, considerase, inicialmente, que o ganho direto, em juros recebidos pela operação com o $C D B$, é definido por

$$
\mathrm{JCDB}^{\mathrm{R}}=\mathrm{CDB}_{\mathrm{m}}-\mathrm{CDB}_{0}
$$

Por outro lado, o custo do carregamento desse CDB, representado aqui por $J C D B^{C}$ dependerá se se trata do agente tipo 1 (capitalizado) ou 2 (descapitalizado). Se for um indivíduo com ampla disponibilidade de recursos, tipo 1, o custo será definido pela taxa $J_{a}$. Assumindo que $J_{a}$ é a própria taxa de juros associada às aplicações em $C D B s$, ocorrerá nesse caso que

$$
\mathrm{JCDB}^{\mathrm{R}}=\mathrm{JCDB}^{\mathrm{C}}
$$

o que implica na inexistência de custos para manutenção da margem, nesse caso.

Alternativamente, uma outra situação extrema seria a de um agente com total falta de capital, tipo 2 , tendo que captar esses recursos no mercado, à taxa $J_{c}$. Nesse caso, $J_{c}>J_{a}$, de onde decorre que 


$$
\mathrm{JCDB}^{\mathrm{R}}<\mathrm{JCDB}^{\mathrm{C}}
$$

A diferença $J C D B^{C}-J C D B^{R}$ corresponde ao custo líquido de carregamento do $C D B$. Se $J_{a}^{d}$ e $J_{c}^{d}$ representam taxas diárias, esse custo seria definido por

$$
\mathrm{JCDB}^{\mathrm{C}}-\mathrm{JCDB}^{\mathrm{R}}=\mathrm{CDB}_{0}\left(1+J_{c}^{d}\right)^{m}-\mathrm{CDB}_{0}\left(1+J_{a}^{d}\right)^{m}
$$

Para facilitar a decomposição dos custos de forma a isolar o componente relacionado à margem de garantia, faz-se a substituição de (22) em (21), e somando e subtraindo $J C D B^{C}$ na expressão resultante, chega-se a

$$
\begin{aligned}
\mathrm{CT}=\mathrm{JCDB}^{C}-\mathrm{JCDB}^{C}-\mathrm{JCDB}^{R}+\mathrm{TO}_{0}+\mathrm{TO}_{\mathrm{m}}- \\
\sum_{t=1}^{m} \mathrm{JR}_{\mathrm{t}}+\sum_{t=1}^{m} \mathrm{JP}_{\mathrm{t}}+\sum_{t=1}^{m} \mathrm{IRPF}_{\mathrm{t}}+\sum_{t=1}^{m} \mathrm{CPMF}_{\mathrm{t}}
\end{aligned}
$$

Dessa forma, ao definir

$$
\mathrm{CMARGEM}=\mathrm{JCDB}^{\mathrm{C}}-\mathrm{JCDB}^{\mathrm{R}}
$$

como o custo da margem, associada ao custo de carregamento do CDB,

$$
\mathrm{TO}=\mathrm{TO}_{0}+\mathrm{TO}_{1}
$$

como o total de taxas operacionais,

$$
\mathrm{TJ}=-\mathrm{JCDB}^{C}-\sum_{t=1}^{m} \mathrm{JR}_{\mathrm{t}}+\sum_{t=1}^{m} \mathrm{JP}_{\mathrm{t}}
$$

como o total de juros pagos ou recebidos relativos à movimentação dos ajustes, deduzidos os juros pagos para manutenção da margem, 


$$
\mathrm{TIRPF}=\sum_{t=1}^{m} \mathrm{IRPF}_{\mathrm{t}}
$$

como o total pago de imposto de renda (IRPF), e

$$
\mathrm{TCPMF}=\sum_{t=1}^{m} \mathrm{CPMF}_{\mathrm{t}}
$$

como o total de CPMF pago na operação. A partir dessas últimas expressões, o custo de transação $(C T)$, apresentado em (23), seria redefinido por

$$
\mathrm{CT}=\mathrm{CMARGEM}+\mathrm{TO}+\mathrm{TJ}+\mathrm{TIRPF}+\mathrm{TCPMF}
$$

Nessa expressão, $C T$ foi decomposto em cinco partes, que também podem ser expressas na forma percentual, com relação a $P_{0}^{f}$, tomando por base o procedimento utilizado na expressão (19). É exatamente essa forma de apresentação que será utilizadas para a exposição dos resultados da mensuração dos custos de transação, a serem discutidos em momento posterior.

\subsubsection{Cálculo com base em séries históricas observadas (método 1)}

Uma primeira estimativa dos custos de transação em mercados futuros utiliza-se de estudo de caso aplicado ao mercado do milho, commodity esta que também servirá de exemplo para os procedimentos posteriores. Foram escolhidos, para análise, os vencimentos relativos aos meses de: maio de 2002 (MAI02), janeiro de 2003 (JAN03), março de 2003 (MAR03) e maio de 2003 (MAI03). Fez-se tal escolha por se tratarem dos meses mais próximos à colheita do milho convencional, sendo que todos os outros possíveis meses foram desprezados. Vencimentos JAN, MAR e MAI, anteriores a MAI02, foram excluídos por terem como base um contrato com especificações diferentes dos analisados. Já os posteriores a MAI03 não foram considerados por estarem relativamente distantes do seu vencimento, à época da pesquisa. 
O baixo volume negociado desta commodity na $\mathrm{BM} \& \mathrm{~F}$, fato que torna problemático alguns tipos de análise aplicados aos mercados futuros, não influencia de forma tão acentuada o cálculo dos custos relativos à tributação, margem de garantia, ajustes diários e taxas operacionais. Isso porque são custos que dependem, basicamente, da trajetória dos preços determinada em certo período, e não do volume negociado em si. Obviamente, poucos contratos negociados podem não refletir fielmente as expectativas do mercado, mas não é objetivo deste trabalho discutir esse aspecto.

Um fator decisivo a favor do uso de séries históricas observadas é que, caso um agente de mercado tivesse operado nesses vencimentos no mundo real, teria observado exatamente os custos calculados.

Portanto, para cálculo dos custos de transação de séries históricas de preços (vencimentos MAI02, JAN03, MAR03 e MAI03), foi utilizado o Software R (versão 1.7.1) seguindo, resumidamente, os seguintes passos:

- Define-se: o período $m$ a ser considerado (por ex, 60 ou 120 dias), em que serão sempre considerados os últimos dias de operação observada (conta-se do último preço de ajuste observado, para trás); a trajetória de preços a ser analisada, ou seja, qual dos quatro vencimentos; os dias que corresponderão ao final do mês, para efeito de cálculo de tributos (é-se assumido um mês como tendo 22 dias úteis); o tipo de agente a ser analisado (tipo 1 ou 2); as taxas de juros, que para agente tipo 1 são definidas por $J_{a}=J_{c}=1,2 \%$ ao mês, e para o agente tipo 2 como $J_{a}=1,2 \%$ ao mês e $J_{c}=3,75 \%$ ao mês; o valor da margem, taxas operacionais e alíquotas da CPMF e IRPF.

- Especificados os parâmetros, define-se as regras da operação: admite-se um desembolso para a compra de CDB para depósito da margem requerida, no início da operação; taxas operacionais (TOB, taxa de registro e emolumentos) deverão ser cobradas no início e no final da operação, segundo seus percentuais; dos valores pagos pelas taxas, define-se o valor pago de CPMF, com base na sua alíquota $(0,38 \%)$; ao final de cada mês apura-se a base de cálculo do IRPF (as regras para ambos os tributos podem ser encontradas no Quadro1); dependendo do saldo da conta da operação e do tipo de agente especificado, debita-se ou remunera-se esse 
saldo, diariamente, às taxas de juros de captação ou de remuneração do capital; resgata-se o valor do $\mathrm{CDB}$ ao final da operação, corrigido pela taxa de juros $J_{a}$; também, no dia $m$, apura-se se há necessidade de pagamento da CPMF, a depender do saldo líquido dos ajustes de toda a operação.

- Depois de aplicadas as regras acima especificadas, na série de preços observada, decompõem-se os valores de todos os custos: custo de margem, taxas operacionais, custo de ajuste diário, IRPF e CPMF.

Portanto, a análise descrita acima pode oferecer os custos de transação para os vencimentos especificados, tanto para agentes tipo 1 (capitalizados) como para agentes tipo 2 (descapitalizados), em um certo período de tempo $m$. Com relação à análise com base em séries observadas, apesar de identificar um custo que realmente teria ocorrido, não permite maiores inferências sobre resultados de outras operações (que correspondam a outras trajetórias de preços). Tal análise só será conseguida através de métodos a serem apresentados a seguir, em que a técnica de simulação é utilizada.

\subsubsection{Simulação Monte Carlo: modelos ARIMA-GARCH (método 2)}

Para se apossar dos benefícios trazidos pela utilização da técnica de simulação e conseguir capturar aspectos relevantes da realidade, a presente pesquisa baseou-se, em um primeiro momento, em testes de modelos denominados ARIMA-GARCH. De uma maneira mais geral, Simon (1996) explica que simulação é uma técnica essencial para o entendimento de sistemas complexos, principalmente quando o comportamento desse sistema não pode ser facilmente compreendido através das características das partes que o compõe.

Como forma de possibilitar o uso de Simulação Monte Carlo (uma das técnicas mais empregadas nesse contexto) no cálculo dos custos de transação em mercados futuros, apresenta-se um modelo simplificado que se baseia no trabalho de Osborne (1959). Para modelar o comportamento de séries temporais de preços, o autor, tomando como base a evolução dos preços de ações na Bolsa de Nova Iorque, argumenta que a diferença entre os logaritmos naturais de preços observados entre dois períodos teria distribuição normal. Isso pode ser expresso da seguinte forma 


$$
\ln \left(P_{t}\right)=\ln \left(P_{t-1}\right)+r_{t}
$$

Nessa formulação, $r_{t}$ é uma variável aleatória i.i.d. (independente e identicamente distribuída), com distribuição $\operatorname{Normal}\left(0, \sigma^{2}\right)$. Uma conseqüência algébrica direta dessa formulação é

$$
P_{t}=P_{t-1} e^{r_{t}}
$$

em que $e^{r_{i}}$ tem distribuição log-normal, pelas propriedades das distribuições normal e $\log$-normal (Mood et al.,1974), sendo o termo $r_{t}$ definido por $\ln \left(P_{t} / P_{t-1}\right)$.

Porém, o modelo original proposto por Osborne (1959) faz fortes pressuposições sobre o comportamento da variável aleatória $r_{t}$, o que limita sua aplicação a determinados contextos. O que se propõe nesta seção é um tipo de análise mais elaborada, utilizando-se de técnicas mais sofisticadas que surgiram depois da publicação do trabalho de Osborne (1959). Essa abordagem mais complexa configura-se na definição de modelos ARIMA-GARCH, a serem discutidos a seguir.

Os modelos ARIMA, sistematizados didaticamente em livros texto como Box e Jenkins (1976), apresentam recursos abrangentes para caracterização estatística de séries de dados temporais. Os modelos ARIMA podem caracterizar, simultaneamente, num único modelo, 3 aspectos importantes em séries temporais: a autocorrelação (AR), a ordem de integração (I), e a dependência em médias móveis (MA).

Partindo-se da expressão (34) apresentada, o que se deseja identificar é se a função que caracterizará os desvios dos preços $\left(r_{t}\right)$ possui AR, I e MA, e de que ordem. Para compreender como isso será feito, se a série calculada dos desvios $\left(r_{t}\right)$ tiver autocorrelação de ordem $c$, sumarizada por $\operatorname{AR}(c)$, ela pode ser representada por

$$
r_{t}=\theta_{1} r_{t-1}+\theta_{2} r_{t-2}+\cdots+\theta_{c} r_{t-c}+e_{t}
$$


em que $e_{t}$ é um erro aleatório i.i.d, com esperança zero.

Se na série ocorrer efeitos associados à média móvel (MA), de ordem $d$, representada por $\mathrm{MA}(d)$, isso pode ser descrito por

$$
r_{t}=\phi_{1} e_{t-1}+\phi_{2} e_{t-2}+\cdots+\phi_{d} e_{t-d}+e_{t}
$$

em que $e_{t}$ é um erro aleatório i.i.d, com esperança zero.

A situação que inclui, simultaneamente, efeitos autoregressivos e de média móvel, de ordem $c$ e $d$ respectivamente, sumarizada por $\operatorname{ARMA}(c, d)$, pode ser genericamente representada por

$$
r_{t}=\theta_{1} r_{t-1}+\cdots+\theta_{c} r_{t-c}+\phi_{1} e_{t-1}+\cdots+\phi_{d} e_{t-d}+e_{t}
$$

em que $e_{t}$ é um erro aleatório i.i.d, com esperança zero.

A ordem de integração, por sua vez, é definida pelo número de diferenças consideradas para a variável de interesse, em que a ordem zero é a própria variável, a ordem 1 é a diferença entre o valor em $t$ e o valor em $t$-1, e assim por diante. Logo, um modelo ARIMA $(c, i, d)$ indica que a autocorrelação é considerada até a ordem $c$, a integração até ordem $i$ e o efeito de média móvel até a ordem $d$. Um modelo ARIMA $(2,1,1)$, por exemplo, seria representado por

$$
\Delta r_{t}=\theta_{1} \Delta r_{t-1}+\theta_{2} \Delta r_{t-2}+\phi_{1} e_{t-1}+e_{t}
$$

em que $e_{t}$ é um erro aleatório i.i.d, com esperança zero.

Nos anos 80, Engle (1982) - ganhador do prêmio Nobel de 2003 - desenvolveu modelos estatísticos que possibilitam uma melhor caracterização de certos fenômenos empíricos relacionados à volatilidade em séries temporais de preços. Em particular, apresenta uma família de modelos denominada ARCH (AutoRegressive Conditional 
Heteroscedastic) para caracterizar (e estimar) o fato empiricamente observado de que em séries de variação de preços, a volatilidade condicional (medida pela variância) tende a ser correlacionada positivamente no tempo, apresentando períodos de volatilidade mais alta e períodos de volatilidade mais baixa. Bollerslev (1986) generaliza o trabalho de Engle (1982), com uma família de modelos denominada GARCH (Generalized AutoRegressive Conditional Heteroscedastic), a qual inclui a família ARCH como caso particular.

A representação geral do modelo $\operatorname{GARCH}(\mathrm{p}, \mathrm{q})$, aplicada especificamente ao modelo (36), definindo por $\Omega_{t-1}$ a informação disponível no período $t$-1, é apresentada a seguir

$$
\begin{aligned}
& r_{t}=E\left(r_{t} \mid \Omega_{t-1}\right)+\xi_{t} \\
& \xi_{t}=z_{t} \sigma_{t} \\
& \sigma_{t}^{2}=a_{0}+\sum_{i=1}^{p} a_{i} \sigma_{t-i}^{2}+\sum_{i=1}^{q} b_{i} \xi_{t-i}^{2}
\end{aligned}
$$

em que $z_{t}$ é uma variável aleatória i.i.d. com esperança zero e variância unitária.

A distribuição de probabilidade de $z_{t}$ não precisa necessariamente ser uma normal. Os parâmetros a serem estimados são $a_{0}, \cdots, a_{p}$ e $b_{1}, \cdots, b_{q}$. O modelo ARCH, desenvolvido por Engle (1982), seria o caso particular do GARCH, quando $p=0$. Nesse modelo, $\sigma_{t}^{2}$ representa a variância condicional do erro, dada a informação disponível até o período $t$-1, ou seja, $\Omega_{t-1}$. Atendidas as restrições quanto aos valores dos parâmetros, explicitadas em Bollerslev (1986), a variância incondicional do erro seria definida por 


$$
\sigma^{2}=\frac{a_{0}}{1-\sum_{i=1}^{p} a_{i}-\sum_{i=1}^{q} b_{i}}
$$

Uma apresentação didática dos modelos GARCH e de outros modelos mais simples, para tratamento da variância condicional, é apresentada por Engle (2001). Andersen et al. (2003) examina aprimoramentos existentes para essa classe de modelos, considerando generalizações multivariadas, métodos alternativos de estimação e outros casos de interesse. A combinação dos modelos ARIMA e GARCH é uma dessas possibilidades que dá acesso a um amplo espectro de modelos para representação do comportamento de séries de preços.

Dessa forma, é exatamente essa classe de modelos que este trabalho utilizará. O que se quer estimar é um modelo ARIMA (c,i,d)-GARCH (p,q) que possa caracterizar satisfatoriamente a evolução das taxas diárias de crescimento dos preços, definida em (34), através do Software R, versão 1.7.1 e do software Ox-G@rch 3.0. Os procedimentos específicos utilizados, detalhados em Azevedo-Filho \& Andrade (2003), são aqui apresentados de maneira simplificada pelos passos seguintes:

- São estimadas as melhores funções para cada um dos quatro vencimentos (MAI02, JAN03, MAR03 e MAI03). Para isso são testados modelos ARIMA (c,d,i), variando $c$ de 0 a $3, i$ de 0 a 1, e $d$ de 0 a 3 , em que a seleção dos melhores modelos são feitas pelo critério BIC (Bayes Information Criterium), desenvolvido por Shwarz (1978). Os resíduos do melhor modelo ARIMA, obtidos em cada uma das séries de preços, são então utilizados para a seleção de um modelo $\operatorname{GARCH}(\mathrm{p}, \mathrm{q}), \operatorname{com} p$ variando de 0 a 2 e $q$ variando de 0 a 2. Esses modelos também são testados pelo critério BIC

- Determinados o melhor modelo ARIMA-GARCH, para cada um dos quatro vencimentos, inicia-se as especificações dos parâmetros para possibilitar a simulação das trajetórias de preços, a partir das funções selecionadas

- Especifica-se: o preço inicial $\mathrm{P}_{0}$; a taxa de variação de preços inicial $\left(r_{0}\right)$; quando requeridos, os parâmetros $\theta, a, b, \phi$, e a ordem de integração, estimados dos melhores modelos ARIMA-GARCH; a variância inicial $\left(\sigma_{0}\right)$ a partir da qual serão 
geradas as variâncias condicionais $(\sigma)$; o período $m$ a ser considerado; o número de simulações $n$ a serem feitas (no caso, igual a 10.000); a função que calcule os custos para cada trajetória simulada, sendo a mesma do MÉTODO 1, pois para cada série simulada serão medidos os custos da mesma forma como foi feito nas séries de preço observadas

- Dada as informações acima, inicia-se o processo de simulação, em que os preços diários serão simulados por um período $m, n$ vezes. Partir-se-á de um preço $\mathrm{P}_{0}$, estipulado arbitrariamente, sendo simulado o preço do dia posterior conforme $P_{1}=P_{0} e^{r_{t}}$. Todavia, esse modelo pode não assumir variância constante durante todo o período.

- Para cada trajetória simulada, serão calculados os custos referentes: à margem de garantia, aos ajustes diários, CPMF, IRPF e às taxas de operações. Dada 10.000 simulações serão geradas distribuições de probabilidade para cada custo de transação, com sua respectiva esperança matemática.

$\mathrm{Na}$ verdade, em alguns dos modelos escolhidos foi verificada autocorrelação entre as taxas, além de dependência das volatilidades (variância condicional). Logo, as variações dos preços têm a possibilidade de serem influenciadas por informações passadas, conforme as especificações dos modelos. É dessa característica que surge a necessidade de se definir a primeira volatilidade, para que as seguintes a tomem como referência para serem simuladas e determinarem os preços seguintes. Essa taxa de variação inicial foi assumida como sendo igual a $r_{0}=\ln \left(\mathrm{P}_{0} / \mathrm{P}_{-1}\right)$, a partir das informações disponíveis no período zero, para cada vencimento.

\subsubsection{Simulação Monte Carlo: modelo simplificado (método 3)}

Um cálculo de simulação mais simples, com base nas pressuposições feitas por Osborne (1959) quanto à distribuição de $r_{t}$, permitirá a obtenção de resultados que, apesar de limitados pelas restrições impostas, pode oferecer uma análise sobre o comportamento dos custos de transação em mercados futuros que outros modelos não proporcionam. Para a compreensão da aplicação desse método simplificado, serão feitas algumas considerações a seguir. 
Ao analisar a expressão (34), ocorre que dada a característica de log-normalidade de $e^{r_{t}}$, o preço no período $t$ também terá distribuição log-normal, o que garante que será estritamente positivo. Isso implica que

$$
E\left(e^{r_{t}}\right)=e^{\mu+\frac{1}{2} \sigma^{2}}
$$

em que $E\left(r_{t}\right)=\mu$ e $\operatorname{Var}\left(r_{t}\right)=\sigma^{2}$ (para essa demonstração, consultar Anexo C).

Uma pressuposição a ser feita é considerar a impossibilidade de previsão dos preços futuros, ou seja, a visão de mercados eficientes (para mais detalhes, consultar Fama, 1970 e Lima, 2003). Essa pressuposição é semelhante à utilizada no famoso modelo Black \& Scholes. Nessa situação, a partir da informação existente até o período $t$-1, para garantir que

$$
E\left(P_{t}\right)=P_{t-1}
$$

é necessário que $E\left(e^{r_{t}}\right)=1$, ou seja, que a condição

$$
E\left(r_{t}\right)=-\frac{1}{2} \sigma^{2}
$$

seja verificada.

Feitas essas pressuposições, o que se verifica é que esse modelo, ao pressupor a distribuição de probabilidade de $r_{t}$, e sendo sua esperança matemática uma função da variância, depende apenas desta última informação, ou seja, da variância das taxas de variação de preço. Dessa forma, o problema está apenas em estimar esse parâmetro para que se consiga modelar trajetórias de preços.

Neste modelo, o desvio padrão $\sigma$, é freqüentemente usado para caracterizar a volatilidade do comportamento dos preços (por exemplo, Harwood et al., 2002). Se o tempo é medido em dias, $\sigma$ será caracterizado como a volatilidade diária, que costuma 
ser expressa na base anual, por $\sigma \sqrt{m}$, onde $m$ é o número de dias de funcionamento do mercado (245 a 260, em geral, assumido 254 nesse trabalho). Esse resultado pode ser obtido facilmente, partindo do fato de que, nesse modelo, o preço em $t+m$ dependerá das várias taxas de variação futuras observadas, de acordo com

$$
P_{t+m}=P_{t} e^{r_{1}+r_{2}+\ldots+r_{m}}
$$

em que $R_{m}=r_{1}+r_{2}+\ldots+r_{m}$, representa a taxa de variação no período $m$. Mas,

$$
V\left(R_{m}\right)=V\left(r_{1}+r_{2}+\ldots+r_{m}\right),
$$

e, pelo fato das taxas serem consideradas i.i.d e pelas propriedades da variância,

$$
V\left(R_{m}\right)=\sigma^{2} m
$$

Decorre dessa última expressão, que o desvio padrão de $R_{m}$, representado por $\sigma_{m}$, é definido por

$$
\sigma_{m}=\sigma \sqrt{m}
$$

em que $\sigma$ é a volatilidade diária e $m$ é o período considerado em dias.

Descrito o método no qual se basearão as trajetórias de preços, para construir o processo de simulação, a partir do modelo simplificado proposto originalmente por Osborne (1959), utilizou-se o Software R (versão 1.7.1), para implementação dos procedimentos. Cabe ressaltar que um modelo particular do Método 2 anteriormente apresentado, ARIMA $(0,0,0$,$) -GARCH (0,0)$, é exatamente o caso apresentado nesse presente método. Os procedimentos para essa simulação, detalhados em Azevedo-Filho 
\& Andrade (2003), são aqui apresentados de maneira simplificada pelos passos seguintes:

- Primeiramente, devem ser especificados os seguintes parâmetros: o preço inicial $\left(\mathrm{P}_{0}\right)$ a partir do qual serão geradas as trajetórias; a volatilidade $\sigma \operatorname{dos} \operatorname{desvios}\left(r_{t}\right)$, que pode ser calculada a partir de séries históricas de preços; $\mu$, que é a esperança matemática da distribuição das taxas de variação, dependente da volatilidade; o período $m$ a ser considerado; a quantidade $n$ que cada trajetória de preços será simulada.

- Também, de início, deverá ser explicitada uma função que calcule as variáveis a serem determinadas (no caso, os custos), para cada trajetória de preços simulada. Essa função é a mesma descrita no Método 1, especificado anteriormente. Isso porque, dado que a primeira trajetória foi simulada, é como se ela fosse uma trajetória observada, necessitando apenas ser implementada a rotina apresentada no método anterior.

- Depois de determinados os parâmetros e a função, o software deverá simular trajetória de preços, de período $m, n$ vezes. Isso será feito seguindo o processo de trajetória de preços descrito por Osborne (1959), em que $P_{t}=P_{t-1} e^{r_{t}}$, implicando que o preço de um dia será o preço do dia anterior, mais um desvio aleatório dado por $r_{t}$, que tem distribuição Normal $\left(0, \sigma^{2}\right)$.

- Para cada trajetória simulada, serão calculados os custos referentes: à margem de garantia, aos ajustes diários, CPMF, IRPF e às taxas de operações. Dada 10.000 simulações serão geradas distribuições de probabilidade para cada custo de transação, com sua respectiva esperança matemática.

A vantagem desse método simplificado é que se configura como um problema mais simples de ser resolvido na forma computacional. As simplificações nele embutidas permitem fazer certos tipos de análise, que em um modelo mais complexo seriam mais difíceis. Exemplos das possibilidades permitidas por esse modelo é que se pode comparar o efeito de diversos patamares de volatilidade, nos distintos custos de 
transação. Porém, a desvantagem é que em certos casos, o modelo teórico assumido pode não ser aderente à realidade, fazendo com que as inferências não sejam próximas ao que realmente é constatado. 


\section{PROPOSTAS DE SISTAMATIZAÇÃO: RESULTADOS}

\subsection{Sistematização dos custos de transação em mercados futuros}

Como primeiro resultado desta pesquisa, tem-se uma proposta de sistematização dos custos de transação de operações em mercados futuros. Essa proposta visa apresentar alguns possíveis componentes do custo total de uma operação, facilitando seu estudo. Dada a dispersa literatura sobre esse assunto específico, uma sistematização inicial aplicada à realidade brasileira pode auxiliar o entendimento de certos problemas pouco explorados até então.

Com relação a esse tipo de proposta, Hobbs (1997), por exemplo, alerta que a complexa natureza das instituições econômicas implica que custos de transação não são fáceis de medir, muito menos de sistematizar. Dorward (2001) também entende que há dificuldades inevitáveis em estudar os custos de transação empiricamente, identificá-los e estimá-los. Contudo, o que se busca é suplantar essas barreiras e dificuldades, possibilitando um avanço dos estudos nessa área.

Apesar de toda classificação ser arbitrária, nota-se sua importância quando autores como Williamson (1985) e Milgrom \& Roberts (1992) fazem suas críticas ao seminal trabalho de Coase (1937). Aqueles autores argumentam que um problema do trabalho de Coase (1937) foi a ausência de uma sistematização de suas idéiase, que não possibilitavam um avanço no estudo sobre custos de transação, apesar do conceito ser importante. Assim sendo, esse é um dos desafios e uma possível contribuição deste trabalho, principalmente porque, na revisão de literatura abordada, não foi encontrada classificação semelhante. 
Um primeiro esclarecimento a ser feito refere-se a dois conceitos distintos, mas com alguns efeitos em comum quando aplicados às operações em mercados futuros. $\mathrm{O}$ primeiro conceito é o de risco de base, muito abordado na literatura da área de derivativos, que implica em uma incerteza ao agente que faz operações de hedging quanto ao preço que realmente irá assegurar (consultar seção 2.5). O outro conceito, aplicado em Azevedo-Filho \& Andrade (2003), é o de risco de custo, que também tem o efeito de inserir incerteza na operação, porém, independente do agente ser um hedger típico ou não. Isto é, o risco de custo independe das operações no mercado físico - isso ficará mais claro adiante - diferentemente do risco de base. Mas ambos causam incerteza na operação.

Dessa forma, o que se propõe neste trabalho é uma sistematização dos potenciais custos de transação inerentes a operações em mercados futuros. Obviamente, os diferentes tipos de agentes (hedgers e especuladores, grandes e pequenos investidores, pessoas experientes e iniciantes) e diferentes mercados (milho, dólar, ouro) terão custos distintos, sendo mais ou menos importantes em cada situação. Portanto, os custos de transação considerados neste trabalho, que independem de operações em mercado físico, são sistematizados em sete categorias:

- Custos de aprendizado e capacitação

- Custos associados a taxas da bolsa e corretoras

- Custos de liquidez do mercado

- Custos de administração da operação

- Custos de margem de garantia

- Custos de ajustes diários

- Custos de tributação

Tal caracterização objetiva clarificar os fatores que influenciam o benefício líquido de operações em mercados futuros, auxiliando futuros trabalhos na área. Uma clara definição desses custos de transação é apresentada de forma sucinta a seguir. 


\subsubsection{Custos de aprendizado e capacitação}

Agentes de mercado que nunca operaram em mercados futuros, claramente, terão de alocar certa quantidade de recursos (dinheiro e/ou tempo) para aprender e capacitarse. Isso pode se configurar em uma considerável barreira à entrada de novos participantes (Hirshleifer, 1988). Tal necessidade deve-se à complexidade das operações em mercados futuros (Ennew et al., 1992), além do que a falta de habilidade e experiência nessas operações, são um dos maiores motivos pelo insucesso de firmas e agentes do mercado (Hieronymus, 1977).

Como o talento e habilidade, nas negociações em mercados futuros, são difíceis de desenvolver, uma possível redução nos custos de aprendizado e capacitação pode ser conseguida através de cursos oferecidos pelas instituições governamentais ou pelas próprias bolsas, bem como publicações destinadas a públicos específicos, eventos de divulgação, dentre outros (Harwood et al., 2002).

Uma possível evidência da existência desses custos é refletida no fato de que pequenos produtores preferem contratos a termo, em vez de negociar em mercados futuros, tendo como um possível argumento a menor complexidade (com conseqüente menor necessidade de aprendizado e capacitação) da transação (Sonka \& Patrick, 1984). Outra possível forma de perceber importância nos custos de aprendizado e capacitação, são os esforços que a própria $\mathrm{BM} \& \mathrm{~F}$ faz, buscando dar treinamento a possíveis participantes do mercado, e financiamento de cursos aos agentes do setor agrícola brasileiro.

Por fim, cabe ressaltar uma peculiaridade dessa modalidade de custo. Uma forma de encarar esses custos pode ser através de aprendizado formal, na forma de cursos, leituras, e outras formas de obtenção de informação, que exigem utilização de recursos. Uma segunda possibilidade é o que se denomina, na literatura especializada internacional, learning by doing. Ou seja, um aprendizado que só se consegue operando, através da experiência na atividade. Isso também pode implicar em perdas (custos) iniciais que não ocorreriam se houvesse uma maior experiência no processo, por parte do agente de mercado. 


\subsubsection{Custos associados a taxas de bolsa e corretoras}

Esses custos são os mais explícitos em mercados futuros, sendo facilmente percebidos pelas pessoas que operam, e os mais enfatizados por boa parte dos livros textos sobre derivativos. $\mathrm{Na} \mathrm{BM} \& \mathrm{~F}$, resumem-se, basicamente, à cobrança de três taxas: emolumentos, taxa operacional básica e taxa de registro. Os valores são divulgados pela bolsa, proporcionais ao volume de negociação. Todavia, as corretoras podem negociar os percentuais cobrados da parte que lhes cabem (TOB), caso o volume negociado seja alto, como forma de atrair um maior número de clientes.

\subsubsection{Custos de liquidez do mercado}

Proposto, seminalmente, por Demsetz (1968), o custo de liquidez reflete o problema do imediatismo na demanda e oferta por contratos. A diferença dos preços de compra e venda, determinado pelos agentes especializados que dão liquidez ao mercado, é uma possível forma de mensuração do custo de liquidez, denominada ask-bid spread. A importância dessa argumentação resultou em diversos outros trabalhos sobre o assunto, apesar de não haver consenso quanto as reais conseqüências dessa modalidade de custo.

Thompson \& Waller (1988) fazem uma boa revisão bibliográfica sobre o assunto e comparam diversas medidas de ask-bid spread. Argumentam que devido ao fato de esse fenômeno não ser facilmente observável, muitos trabalhos buscam formas de estimá-lo. Ressaltando a importância desse tipo de trabalho, Brorsen (1989) chama a atenção que não só especuladores e hedgers devem saber a magnitude do custo de liquidez, mas também pesquisadores, para levá-los em conta quando da simulação de estratégias de negociações em mercados futuros.

\subsubsection{Custos de administração da operação}

O que se define por custo de administração da operação, compreende os recursos (tempo e/ou dinheiro) despendido pelo agente, para levar a transação em mercados futuros desde o dia da abertura até o fechamento do contrato. Considerando que esses recursos poderiam ser utilizados para outras finalidades, isso se configura em custo. Essa 
é exatamente a idéia de custo de oportunidade, o qual diz que se um recurso qualquer for utilizado para uma dada finalidade, as receitas potenciais de usos alternativos serão perdidas (Ross, 1995). Essa modalidade diferencia-se do custo de aprendizado (que também possui um caráter de custo de oportunidade) porque, um agente ao especializarse na negociação, quase que elimina o custo de aprender e capacitar-se. Por outro lado, o custo de administração, mesmo podendo ser minimizado com o decorrer do tempo, sempre existirá à medida que o agente continue transacionando em mercados futuros.

Analisando o caso simplificado de um produtor rural, este possui diversos afazeres tais como: preocupação com preparo de solo e adubação, compra de insumos, contratação de mão-de-obra, aplicação de defensivos, colheita, comercialização etc. Todas essas atividades consomem tempo e devem ser feitas de maneira satisfatória para o sucesso do empreendimento. No caso desse produtor decidir operar em mercados futuros, terá de alocar parte do seu tempo para administrar sua posição, abrindo mão de certas atividades relacionadas diretamente à produção. Em um extremo, isso pode se configurar em um custo muito elevado se a operação em mercados futuros implicar que ele deixe de fazer atividades essenciais na sua propriedade, prejudicando a sua eficiência produtiva.

As atividades que podem demandar tempo para administrar posições em mercados futuros estão relacionadas, por exemplo, à administração de ajustes diários. Periodicamente, o hedger deve comunicar-se com a corretora para verificar a necessidade de se pagar ajustes, tendo também custos de ligações telefônicas, por exemplo (algo citado como custos transacionais de forma sucinta por Demsetz, 1968).

Outra atividade que demanda recursos é a necessidade de intenso acompanhamento do mercado, feito através de obtenção de informações junto aos corretores, leitura de jornais, revistas, Internet, ou até mesmo chegando a ponto de contratar serviços de agências de notícias on line (com custos significativos). Todas essas atitudes visam a obtenção de uma administração mais eficiente possível, sem perda oportunidades. Caso o agente que queira fazer o hedge contrate um profissional especializado apenas para essa finalidade, o salário pago a esta pessoa configura-se em um custo de transação inerente à operação em mercados futuros, na sua forma mais 
evidente. Esses custos podem possuir uma magnitude tal que iniba a entrada de novos agentes nesse mercado. Vide o exemplo de pequenos produtores rurais, que preferem contratos a termo por serem de mais simples administração (Sonka \& Patrick, 1984).

\subsubsection{Custos de margem e ajustes}

A definição do que se entende por custos financeiros associados à margem de garantia e ajustes diários é fundamental para a presente pesquisa, pois é um dos custos a ser mensurado. Sua natureza está relacionada à necessidade de, na abertura de uma negociação em mercados futuros, se fazer um depósito de margem de garantia (em que seu valor é um percentual fixo do volume de contratos negociados, consultar Tabela 3) e até o encerramento existir a possibilidade de pagamentos relativos aos ajustes diários (além de possíveis chamadas de margem).

A idéia de custos financeiros está associada ao fato do capital financeiro possuir um custo de oportunidade. Tal pensamento é análogo à idéia de custo de margem proposta por autores como Telser (1981), Hartzmark (1986) e Adrangi \& Chatrath (1999), que propõem que o dinheiro depositado em margem tem um caráter distinto do dinheiro fora dela, havendo um custo esperado caso se opere em mercados futuros. Porém, o que se propõe na presente pesquisa é uma análise mais abrangente do que a exposta por esses autores.

A natureza do problema está relacionada ao fato de que uma empresa ou indivíduo possui um certo limite de capital próprio, que deverá ser alocado (da forma mais eficiente possível) entre suas diversas necessidades. Caso venha a operar em mercados futuros, uma parte desse capital será destinada à margem de garantia, sendo que tal quantia deverá permanecer intocável até o final da transação. Outra parte cobrirá os eventuais ajustes diários negativos que essa empresa ou indivíduo tenha que pagar durante a vigência do contrato, e também para possíveis chamadas de margem (essa possibilidade será desconsiderada neste trabalho).

Dessa forma, o dinheiro depositado em margem e o gasto esperado com ajustes diários, não podem ser alocados para outras possíveis aplicações (compra de maquinários e insumos, aplicação financeira etc), tendo, portanto, um custo de 
oportunidade esperado. Argumenta-se que esse custo financeiro seria diretamente influenciado pela relação entre capital próprio e quantidade de contratos futuros negociados. Quanto maior o volume de contratos negociados e quanto menor a disponibilidade de capital, aumenta-se a possibilidade de esgotamento dessa reserva financeira, obrigando o indivíduo ou firma a encerrar a posição, ou captar dinheiro no mercado a uma certa taxa de juros - provavelmente maior que o custo de oportunidade do capital próprio.

A escassez de capital para manter os compromissos exigidos no início (depósito de margem) e durante a vida do contrato (ajustes diários negativos), é uma suposição muito factível, ainda mais se aplicado no contexto do mercado agrícola brasileiro, em que a descapitalização, de maneira geral, é notória. Tal fato suscita a problemática de que uma operação em mercados futuros pode diminuir o risco de preço, mas aumentar o risco de fluxo de caixa de quem opera, pois a empresa ou indivíduo pode não suportar sucessivos ajustes diários negativos (Carvalho, 1999). Mesmo não se considerando possíveis chamadas de margem, é óbvio que a inserção dessa peculiaridade apenas aumentaria os custos financeiros.

\subsubsection{Custos relativos à tributação}

A tributação é outro custo de transação presente em operações de hedge, que o presente trabalho pretende explorar mais profundamente, buscando não só o seu detalhamento, mas também sua mensuração. As informações, sobre a característica de todos os tributos e suas peculiaridades relevantes às operações em mercados futuros, foram de difícil obtenção por ser um tema muito específico e de conhecimento fragmentado entre as pessoas de mercado.

A seguir, serão apresentados todos os possíveis impostos incidentes nas operações em futuros, focando na apresentação de informações, principalmente, no que tange às leis que regulam tal cobrança e a natureza dos impactos dos referidos tributos nas operações. Isso porque a sistematização detalhada e simplificada das alíquotas, e modo de tributação, será apresentada na seção seguinte, no Quadro 2. . 
a) Imposto de Renda e CSLL

Em mercados futuros, a cobrança do imposto de renda da pessoa física (IRPF) é regulada pela IN da SRF 25/01. A alíquota é cobrada sobre o ganho líquido, definido como sendo o resultado positivo da soma algébrica dos ajustes diários ocorridos em cada mês (art. 28). Tal valor deve ser pago até o último dia útil do mês subseqüente ao da apuração (art. 23, $\S 4^{\circ}$ ), podendo-se deduzir os custos e despesas incorridos, necessários à realização da operação. Todavia, se a pessoa física obtiver uma perda líquida em um dado mês (ou seja, se a soma dos ajustes negativos forem superiores aos ajustes positivos), não será tributado e poderá compensar essa perda na tributação dos eventuais ganhos dos meses subseqüentes (art. 23, $\S 3^{\circ}$ ).

Em se tratando da tributação em mercados futuros, para pessoa jurídica, a diferença básica é que na apuração feita pelo lucro real, os ajustes líquidos positivos obtidos nas operações em mercados futuros irão fazer parte do balanço patrimonial da empresa, a partir do qual será cobrado o imposto em caso de lucro no período. No caso de lucro presumido ou arbitrado, os ganhos em operações em futuros serão parte integrante da receita bruta, o que faz sejam diretamente tributáveis (mesmo se a empresa não obtiver lucro, paga o imposto). Sendo que para a pessoa física, o imposto é retido mensalmente na fonte, nota-se que a forma organizacional influenciará nos custos de transação para cada uma dessas possíveis estruturas, o que não será abordado neste trabalho. O impacto da CSLL, apesar de a base de cálculo poder diferir, tende a ser o mesmo do IRPJ.

b) Pis/Pasep e Cofins

A IN da SRF 247/02 (art.10, § $1^{\circ}$ ) prevê que nas operações realizadas em mercados futuros, considera-se parte integrante da receita bruta para fins de tributação, o resultado líquido positivo dos ajustes diários ocorridos em cada mês. Dessa forma, se a soma algébrica dos ajustes diários for positiva, em dado mês, esse valor integrará a base de cálculo da pessoa jurídica (lucro real, presumido ou arbitrado) quando da incidência de Pis/Pasep e Cofins, sem que os resultados negativos em um período de apuração, 
possam ser abatidos da tributação de possíveis ajustes positivos em meses futuros, como acontece com o IRPF.

Tal fato pode acarretar custos diretos, como exemplificado a seguir. Se, para efeito de ilustração, um indivíduo vende contratos futuros a um preço hipotético de dez unidades monetárias $(\$ 10)$, e ao final do primeiro mês esse preço está $\$ 11$, deve pagar as contribuições sobre os ajustes diários recebido, pois fazem parte da receita bruta do período. Se no mês seguinte o preço cai a $\$ 10$, a pessoa jurídica paga a diferença sob a forma de ajuste diário, sem poder abater a tributação incidente no mês anterior. Como saldo final, o agente de mercado terá um balanço negativo. Isso porque recebeu $\$ 1 \mathrm{e}$ foi tributado pelo Pis/Pasep e Cofins, pagando posteriormente \$1 e não sendo restituído.

\section{c) $\mathrm{CPMF}$}

Com relação à incidência de CPMF em mercados futuros, ela pode acontecer em três momentos: 1) quando do depósito de margem de garantia em dinheiro; 2) como um percentual do total de taxas pagas à bolsa e às corretoras, na entrada e na saída da operação; 3) ao final da operação, caso os ajustes líquidos totais sejam negativos.

Com relação aos itens 1 e 2, que são os depósitos de margem de garantia em dinheiro (e não em títulos) e pagamentos das taxas das bolsas e corretoras, tal tributação ocorre por se tratarem de movimentação financeira (no primeiro caso) e de transferência de titularidade de valores (no segundo), sem que haja qualquer isenção legal para esses casos.

Por outro lado, conforme o artigo 8, da lei 9311/96, não há cobrança de alíquota para as transações relacionadas a pagamento e recebimento de ajustes diários (que podem ser feitas via $\mathrm{TED}^{34}$ ), durante a vida do contrato futuro. Mas essa mesma Lei, em seu artigo $2^{\circ}$, diz que o fato gerador da contribuição é a liquidação de operação contratada nos mercados organizados de liquidação futura, e no artigo 6, inciso III,

\footnotetext{
${ }^{34}$ Transferência Eletrônica Disponível. É uma modalidade que permite transferência instantânea entre contas correntes (do mesmo banco ou de outros bancos), em que o atual limite mínimo de 5 mil reais por transferência não se aplica a operações em mercados futuros (Comunicado da FEBRABAN de 2002 - esse documento não pôde ser reproduzido e é apenas uma recomendação aos bancos). Informações obtidas por superintendente da FEBRABAN (consultar ANEXO B).
} 
explica que a base de cálculo é o resultado, se negativo, da soma algébrica dos ajustes diários ocorridos no período compreendido entre a contratação inicial e a liquidação do contrato.

\subsection{Resumo da sistematização dos custos de transação}

A seguir, o Quadro 1 apresenta um resumo da proposta de sistematização dos potenciais custos de transação em mercados futuros.

\begin{tabular}{|c|c|}
\hline CUSTO & DESCRIÇÃO \\
\hline $\begin{array}{l}\text { Aprendizagem e } \\
\text { capacitação }\end{array}$ & $\begin{array}{l}\text { Relativo à necessidade de aprender os mecanismos referentes à operação de } \\
\text { hedge. Aprendizado e capacitação utilizam recursos (tempo e dinheiro), e é de } \\
\text { fundamental importância para o sucesso da administração da operação }\end{array}$ \\
\hline $\begin{array}{l}\text { Taxas da bolsa e } \\
\text { corretoras }\end{array}$ & $\begin{array}{l}\text { São as taxas pagas à bolsa e corretoras (emolumento, TOB e taxa de registro). } \\
\text { Correspondem a um percentual do total de contratos negociados }\end{array}$ \\
\hline $\begin{array}{l}\text { Administração da } \\
\text { operação }\end{array}$ & $\begin{array}{l}\text { São as despesas relacionadas à alocação de recursos (tempo ou dinheiro) para } \\
\text { a manutenção da operação, compreendendo desde o seu início até o seu } \\
\text { término. Uma possível maneira de simplificar essa análise é na hipótese da } \\
\text { contratação de um agente especializado apenas para fazer as operações. O } \\
\text { salário pago a esse indivíduo seria o custo na sua forma mais explícita }\end{array}$ \\
\hline Liquidez do mercado & $\begin{array}{l}\text { Refere-se ao custo relacionado à necessidade de imediatismo nas negociações. } \\
\text { Os agentes especializados que operam no mercado apenas para dar liquidez } \\
\text { (sempre dispostos a comprar e vender), cobram por esse serviço. O ask-bid } \\
\text { spread é uma possível medida desse custo, expresso na diferença entre as } \\
\text { ofertas de compra e venda dos agentes no pregão. Quanto mais liquidez no } \\
\text { mercado, menor esse custo. }\end{array}$ \\
\hline Margem e ajustes & $\begin{array}{l}\text { Todo agente ou empresa que opere em mercados futuros, terá que depositar } \\
\text { certa quantia de dinheiro em margem de garantia, e ter certo volume } \\
\text { financeiro para possíveis chamadas de margem e depósitos de ajustes diários. } \\
\text { Em caso do capital próprio ser utilizado para esses fins, possuem um custo de } \\
\text { oportunidade. Se a empresa ou agente não possuir capital, deverá emprestar } \\
\text { um montante, sendo que essa taxa de juros de captação provavelmente será } \\
\text { maior que a taxa de remuneração do capital próprio }\end{array}$ \\
\hline Tributação & $\begin{array}{l}\text { Existe tributação nas operações de mercados futuros, que variam conforme a } \\
\text { estrutura organizacional. No caso de pessoa física é cobrado apenas IRPF, } \\
\text { enquanto para pessoa jurídica, estão sujeitos à IRPJ, CSLL, Pis/Pasep, Cofins. } \\
\text { Tais tributos incidem sobre ajustes líquidos positivos obtidos em determinado } \\
\text { período. No caso da CPMF, que é cobrado de qualquer tipo de agente, } \\
\text { configura-se por um percentual, incidente sobre as taxas pagas à bolsa e } \\
\text { corretoras, e pode também ser cobrado caso os ajustes líquidos do total da } \\
\text { operação sejam negativos }\end{array}$ \\
\hline
\end{tabular}

Quadro 1 - Potenciais custos de transação em mercados futuros. 


\subsection{Tributação e estrutura organizacional}

A sistematização dos custos de transação relativos à tributação de operações em mercados futuros, com certeza, é uma das maiores contribuições deste trabalho. Essa convicção é baseada na superficialidade de tratamento desse assunto por parte da literatura especializada e, principalmente, por tal problema ter sido diagnosticado através de diálogos com pessoas ligadas diretamente ao mercado, o que reafirma sua importância prática. Mas até para esses especialistas, com vasto conhecimento do mercado financeiro, o assunto de tributação não é de tão fácil compreensão, muito menos o são seus reais impactos econômicos. Dessa forma, a abordagem dos custos de transação, sistematizando-os e mensurando-os, é de importância não só acadêmica, mas também (e principalmente) para os agentes que operam nesse mercado.

A compilação das informações obtidas foi uma das tarefas mais árduas desta pesquisa. Elas encontravam-se dispersas entre os agentes de mercado, que sabiam de forma superficial sobre o assunto de tributação, fato esse que obrigou a um intenso trabalho de pesquisa em uma literatura pouco usual em trabalhos de economia, além da necessidade do auxílio periódico de um especialista em tributação.

Por todo esse esforço citado e, principalmente, pela ausência na literatura de uma sistematização dos tributos incidentes nos mercados futuros brasileiro, com o grau de detalhamento aqui presente, é que se decidiu incluir o Erro! A origem da referência não foi encontrada. como resultado de pesquisa. Ela traz informações sobre as alíquotas cobradas dos tributos, para cada tipo de agente (pessoa jurídica tributada pelo lucro real, presumido ou arbitrado, e pessoa física), as bases de cálculos, os fatos geradores das cobranças dos impostos e contribuições, e suas formas de pagamento. 


\begin{tabular}{|c|c|c|c|c|c|}
\hline & 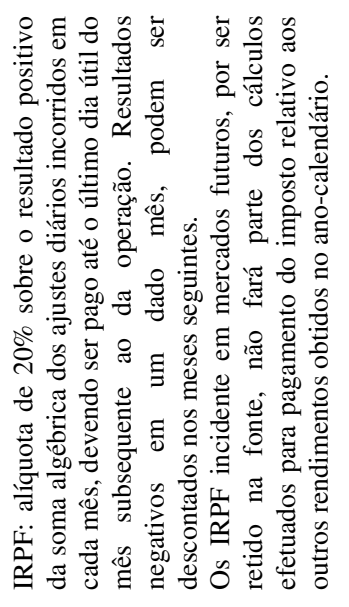 & 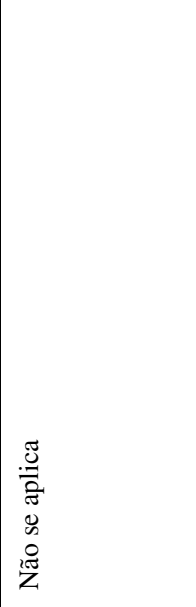 & 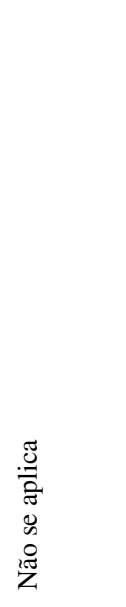 & 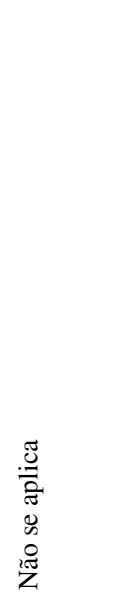 & 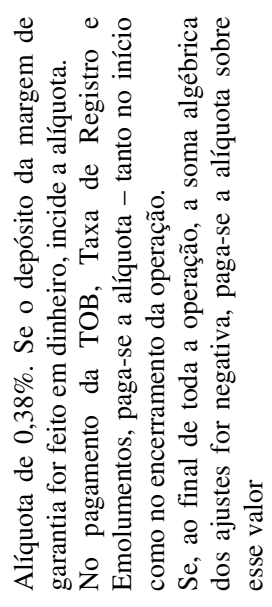 \\
\hline 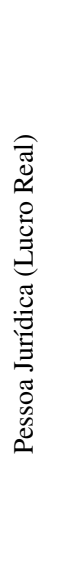 & 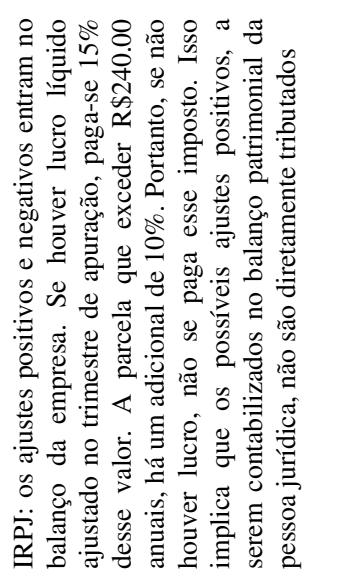 & 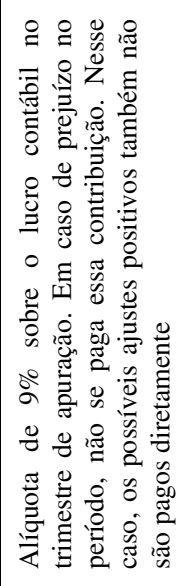 & 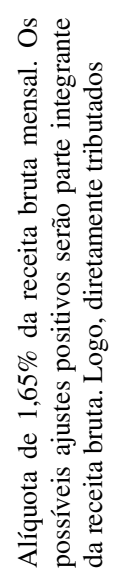 & 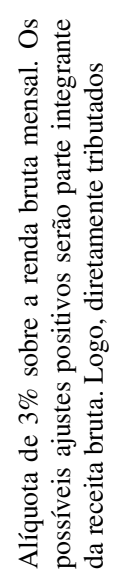 & 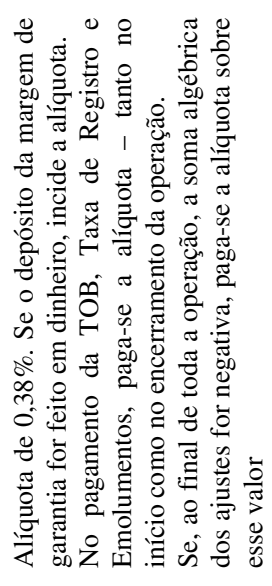 \\
\hline 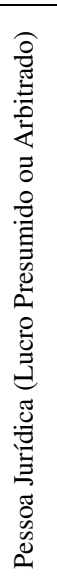 & 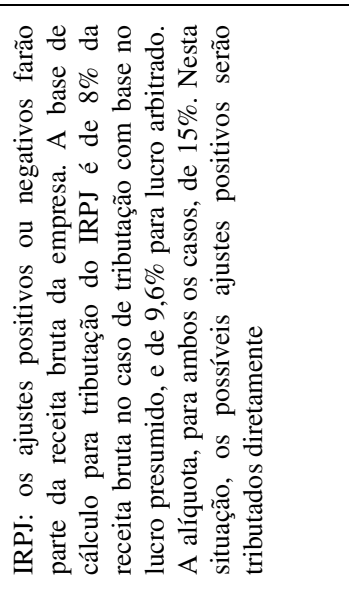 & 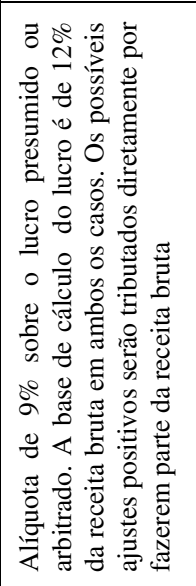 & 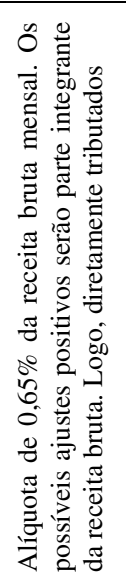 & 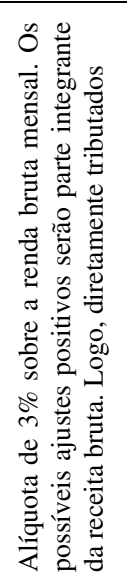 & 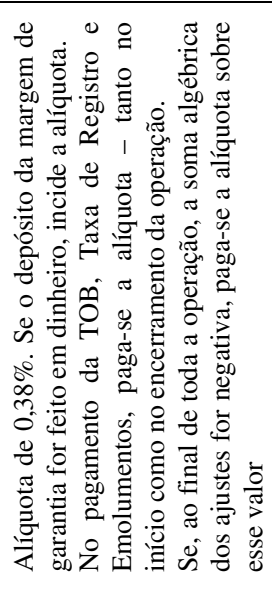 \\
\hline 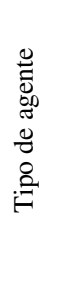 & 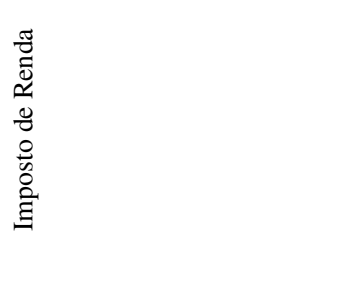 & $\overrightarrow{\vec{v}}$ & $\begin{array}{l}\frac{0}{\sqrt{2}} \\
\frac{1}{2} \\
\frac{1}{2} \\
0\end{array}$ & $\begin{array}{l}\sum_{\pi}^{n} \\
\frac{\pi}{8}\end{array}$ & $\sum_{i}^{\infty}$ \\
\hline
\end{tabular}




\section{MENSURAÇÃO DOS CUSTOS DE TRANSAÇÃO: RESULTADOS ${ }^{35}$}

A seguir, serão apresentados resultados referentes a três formas de mensuração dos custos de transação associados a operações em mercados futuros: custos de margem, ajuste, tributação e taxas operacionais. O Método 1 analisa séries históricas de preços futuros. O Método 2 utiliza de Simulação Monte Carlo, através do uso de modelos ARIMA-GARCH. Por último, o Método 3 também configura-se pela aplicação de técnica de simulação, porém, baseada em modelos simplificados, que levam em consideração apenas a volatilidade dos preços. Os resultados de todas as análises trazem informações peculiares que tornam os métodos utilizados complementares, auxiliando no claro entendimento da natureza dos custos.

\subsection{Resultados do Método 1}

Para a mensuração dos custos de transação através de séries históricas, foram utilizados os seguintes vencimentos do contrato do milho (BM\&F): MAI02, JAN03, MAR03 e MAI03. Conforme procedimentos descritos na seção 4.2.3, foram calculados: a participação relativa de cada custo de transação analisado (margem, ajuste, IRPF, CPMF e taxas de bolsa e corretoras) e o custo total da operação, assumindo uma operação de venda de contratos. A seguir são apresentadas tabelas que demonstram a influência de dois aspectos: duração da operação e tipo do agente.

\footnotetext{
${ }^{35}$ Os resultados apresentados fundamentam-se fortemente em Azevedo Filho \& Andrade (2003), que deve ser consultado para detalhes adicionais.
} 
Tabela 6. Custos de transação estimados em trajetórias de preços observadas no contrato de milho (BM\&F) para agentes tipo 1 (capitalizados).

\begin{tabular}{lcccc}
\hline \multirow{2}{*}{\multicolumn{1}{c}{ Componente }} & \multicolumn{4}{c}{ Custos como percentagem do valor inicial do contrato } \\
\cline { 2 - 4 } & MAI02 & JAN03 & MAR03 & MAI03 \\
\cline { 2 - 5 } Margem & $0,00 \%$ & $0,00 \%$ & $0,00 \%$ & $0,00 \%$ \\
Taxas operacionais & $0,71 \%$ & $0,83 \%$ & $0,69 \%$ & $0,63 \%$ \\
Ajustes & $0,09 \%$ & $3,12 \%$ & $-0,03 \%$ & $-0,51 \%$ \\
IRPF & $1,75 \%$ & $0,00 \%$ & $1,82 \%$ & $3,11 \%$ \\
CPMF & $0,08 \%$ & $0,23 \%$ & $0,06 \%$ & $0,002 \%$ \\
Custo Total & $2,63 \%$ & $4,18 \%$ & $2,55 \%$ & $3,23 \%$ \\
\hline
\end{tabular}

Fonte: Azevedo-Filho \& Andrade (2003)

Tabela 7. Custos de transação estimados em trajetórias de preços observadas no contrato de milho (BM\&F) para agentes tipo 2 (descapitalizados).

\begin{tabular}{lcccc}
\hline \multirow{2}{*}{ Componente } & \multicolumn{4}{c}{ Custos como percentagem do valor inicial do contrato } \\
& MAI02 & JAN03 & MAR03 & MAI03 \\
\cline { 2 - 4 } Margem & $1,72 \%$ & $1,27 \%$ & $0,99 \%$ & $0,92 \%$ \\
Taxas operacionais & $0,71 \%$ & $0,83 \%$ & $0,69 \%$ & $0,63 \%$ \\
Ajustes & $0,25 \%$ & $9,86 \%$ & $-0,05 \%$ & $-1,17 \%$ \\
IRPF & $1,75 \%$ & $0,00 \%$ & $1,82 \%$ & $3,11 \%$ \\
CPMF & $0,08 \%$ & $0,23 \%$ & $0,06 \%$ & $0,002 \%$ \\
Custo Total & $4,51 \%$ & $12,20 \%$ & $3,52 \%$ & $3,49 \%$ \\
\hline
\end{tabular}

Fonte: Azevedo-Filho \& Andrade (2003) 
Tabela 8. Custos de transação estimados em trajetórias de preços observadas no contrato de milho $(B M \& F)$ para agentes tipo 1.

\begin{tabular}{lcccc}
\hline \multirow{2}{*}{ Componente } & \multicolumn{3}{c}{ Custos como percentagem do valor inicial do contrato } \\
\cline { 2 - 4 } & MAI02 & JAN03 dias) & MAR03 & MAI03 \\
Margem & $0,00 \%$ & $0,00 \%$ & $0,00 \%$ & $0,00 \%$ \\
Taxas & $0,72 \%$ & $0,64 \%$ & $0,74 \%$ & $0,67 \%$ \\
Ajustes & $0,22 \%$ & $0,14 \%$ & $0,23 \%$ & $0,29 \%$ \\
IRPF & $0,00 \%$ & $1,56 \%$ & $0,21 \%$ & $0,00 \%$ \\
CPMF & $0,09 \%$ & $0,01 \%$ & $0,11 \%$ & $0,04 \%$ \\
Custo Total & $1,03 \%$ & $2,35 \%$ & $1,28 \%$ & $1,00 \%$ \\
\hline
\end{tabular}

Fonte: Azevedo-Filho \& Andrade (2003)

Tabela 9. Custos de transação estimados, em trajetórias de preços observadas no contrato de milho (BM\&F) para agentes tipo 2.

\begin{tabular}{lcccc}
\hline \multirow{2}{*}{ Componente } & \multicolumn{3}{c}{ Custos como percentagem do valor inicial do contrato } \\
\cline { 2 - 4 } & MAI02 & JAN03 & MAR03 & MAI03 \\
Margem & $0,82 \%$ & $0,38 \%$ & $0,51 \%$ & $0,50 \%$ \\
Taxas & $0,72 \%$ & $0,64 \%$ & $0,74 \%$ & $0,67 \%$ \\
Ajustes & $0,68 \%$ & $0,47 \%$ & $0,67 \%$ & $0,90 \%$ \\
IRPF & $0,00 \%$ & $1,56 \%$ & $0,21 \%$ & $0,00 \%$ \\
CPMF & $0,09 \%$ & $0,01 \%$ & $0,11 \%$ & $0,04 \%$ \\
Custo Total & $2,31 \%$ & $3,06 \%$ & $2,23 \%$ & $2,10 \%$ \\
\hline
\end{tabular}

Fonte: Azevedo-Filho \& Andrade (2003) 
No intuito de analisar, primeiramente, a influência do grau de capitalização de um agente que opere em mercados futuros, as Tabelas 6 e 7 apresentam os valores percentuais dos custos de transação, com base no valor inicial do contrato (conforme especificado na expressão 19, seção 4.2.2). O que se verifica, para uma operação de 120 dias, é que os custos são acentuadamente maiores para os indivíduos descapitalizados (agente tipo 2). Apesar de esse resultado ser esperado, o mais marcante é a magnitude que podem chegar os custos, na condição analisada. Mesmo para um agente capitalizado, nota-se que para a trajetória de preços do vencimento JAN03, o custo foi de $4,28 \%$ do valor inicial do contrato.

Ao levar em consideração um período de 60 dias, com os dados apresentados nas Tabelas 8 e 9, os custos são significativamente menores quando comparados a uma operação de 120 dias, para todos os vencimentos. Tal resultado deriva do fato que um menor período de operação, reduz a incerteza quanto ao fluxo de caixa (há uma maior probabilidade de incidência de tributos e de necessidade de pagamento de ajustes).

Outro ponto interessante, devido ao modo como foi proposta a mensuração dos custos, é que nas tabelas referentes ao agente tipo 1 (capitalizado), o custo de margem foi zero, pois a taxa de remuneração do capital próprio é a mesma de captação $\left(J_{a}=J_{c}\right)$. Já os valores nulos de IRPF em alguns vencimentos, representam trajetórias ascendentes de preço no período, resultando apenas em pagamento de ajustes (não incide esse tributo). Por outro lado, os custos de ajustes são positivos quando a trajetória de preços implica em pagamentos de ajuste (trajetória descendente para o caso de venda de contratos), e os custos negativos tem como motivo recebimento de ajustes e aplicação desse dinheiro, rendendo juros diários.

A análise de séries de preços observadas, apesar de suas limitações, já traz alguns elementos importantes quanto às características dos custos de transação analisados. A primeira delas é a demonstração de sua dependência da trajetória de preços, o que tornam esses custos incertos (nenhum dos vencimentos deu um custo igual ao outro). Uma segunda observação refere-se ao fato de esses custos poderem ser assimétricos entre os agentes, pois, na verdade, os custos incidem tanto para quem vende o contrato 
como para quem compra. Isso implica em transações com um custo ainda maior, se analisado de maneira mais global. Esse fato será explorado melhor posteriormente.

Um exemplo que destaca a assimetria de custos é ilustrado pelo contrato com vencimento em JAN03, em que o preço passou, em 120 dias, de R\$16,20 para R\$ 27,00 , por saca de $60 \mathrm{~kg}$. Se uma operação fosse realizada nesse período, para um contrato de venda, os custos associados a encargos financeiros chegariam a 9,85\% do valor inicial do contrato, o IRPF pago seria nulo e o custo de transação total seria de $4,18 \%$ (agente tipo 1).

Nessa mesma situação, para um contrato de compra, teria havido um recebimento de juros equivalente a 3,57\% (devido à grande quantia recebida de ajustes diários), e um pagamento de IRPF equivalente a 15,06\%, com um custo de transação total de 13,6\% do valor inicial do contrato (agente tipo 1). O que se nota é que se os agentes mantivessem suas posições pelos 120 dias, teriam sido esses os custos observados (4,18\% - venda de contratos; 13,6\% - compra de contratos), que foram muito diferentes (assimétricos) para posições vendida e comprada.

\subsection{Resultados do Método 2}

Apresentados e discutidos os resultados obtidos através de séries de preço observadas, esta seção busca mensurar os custos de transação através do método de simulação Monte Carlo. Nos resultados da seção anterior, um problema para sua análise é que a maioria deles apresentou movimentos de alta de preços. Isso implica que nessa situação, um certo custo em particular pareça mais importante que outro. Esse tipo de viés é eliminado quando se trata de processos de simulação, pois os custos a serem apresentados representam uma média das trajetórias possíveis.

Feita a seleção (descrita na seção 4.2.4) dos melhores modelos ARIMA-GARCH, para os quatro vencimentos analisados, pelo critério BIC, chegou-se aos seguintes modelos e seus parâmetros, apresentados na Tabela 10. 
Tabela 10. Modelos selecionados para representação de cada série.

\begin{tabular}{|c|c|c|}
\hline $\begin{array}{c}\text { Série } \\
\text { de taxas }\end{array}$ & $\begin{array}{c}\text { Estimativas } \\
\text { dos Parâmetros }\end{array}$ & Modelo \\
\hline \multirow[b]{2}{*}{ MAI02 } & $\hat{a}_{0}=0,00008124$ & $\operatorname{ARIMA}(0,0,0)$ \\
\hline & $\hat{b}_{1}=0,3839$ & $\operatorname{GARCH}(0,1)$ \\
\hline \multirow{4}{*}{ JAN03 } & $\hat{\theta}_{1}=0,4614$ & \multirow{4}{*}{$\begin{array}{c}\operatorname{ARIMA}(1,0,0) \\
\operatorname{GARCH}(1,1)\end{array}$} \\
\hline & $\hat{a}_{0}=0,00003164$ & \\
\hline & $\hat{a}_{1}=0,5510$ & \\
\hline & $\hat{b}_{1}=0,3415$ & \\
\hline \multirow{4}{*}{ MAR03 } & $\hat{\theta}_{1}=0,4514$ & \multirow{4}{*}{$\begin{array}{c}\operatorname{ARIMA}(2,0,0) \\
\operatorname{GARCH}(1,1)\end{array}$} \\
\hline & $\hat{\theta}_{2}=-0,1401$ & \\
\hline & $\hat{a}_{0}=0,00007539$ & \\
\hline & $\hat{a}_{1}=0,4234$ & \\
\hline \multirow{6}{*}{ MAI03 } & $\hat{b}_{1}=0,2785$ & \multirow{6}{*}{$\begin{array}{c}\operatorname{ARIMA}(2,0,0) \\
\operatorname{GARCH}(1,1)\end{array}$} \\
\hline & $\hat{\theta}_{1}=0,3688$ & \\
\hline & $\hat{\theta}_{2}=-0,05567$ & \\
\hline & $\hat{a}_{0}=0,00004488$ & \\
\hline & $\hat{a}_{1}=0,2508$ & \\
\hline & $\hat{b}_{1}=0,5513$ & \\
\hline
\end{tabular}

Fonte: Azevedo-Filho \& Andrade (2003)

Escolhidos os melhores modelos para cada trajetória de preços observada, foram feitas simulações para o calculo dos custos de transação pertinentes, conforme explicitado na seção 4.2.4. Os resultados estão apresentados nas Tabelas 11 e 12, para os agentes tipo 1 e 2 , em operações de 120 dias. 
Tabela 11. Custos de transação médios, estimados em 10.000 trajetórias de preços, simuladas a partir de modelos selecionados para agentes tipo 1.

\begin{tabular}{lcccc}
\hline \multirow{2}{*}{ Componente } & \multicolumn{4}{c}{ Custos como percentagem do valor inicial do contrato } \\
\cline { 2 - 4 } & MAI02 & JAN03 & MAR03 & MAI03 \\
\cline { 2 - 4 } Margem & $0,00 \%$ & $0,00 \%$ & $0,00 \%$ & $0,00 \%$ \\
Taxas & $0,64 \%$ & $0,63 \%$ & $0,65 \%$ & $0,64 \%$ \\
Ajustes & $0,07 \%$ & $0,13 \%$ & $0,20 \%$ & $0,03 \%$ \\
IRPF & $1,41 \%$ & $3,67 \%$ & $2,63 \%$ & $2,35 \%$ \\
CPMF & $0,02 \%$ & $0,04 \%$ & $0,04 \%$ & $0,03 \%$ \\
Custo Total & $2,14 \%$ & $4,47 \%$ & $3,52 \%$ & $3,05 \%$ \\
\hline
\end{tabular}

Fonte: Azevedo-Filho \& Andrade (2003)

Tabela 12. Custos de transação médios, estimados em 10.000 trajetórias de preços, simuladas a partir de modelos selecionados para agentes tipo 2 .

Custos como percentagem do valor inicial do contrato

Componente (120 dias)

\begin{tabular}{lcccc}
\cline { 2 - 4 } Margem & MAI02 & JAN03 & MAR03 & MAI03 \\
Taxas & $1,72 \%$ & $1,27 \%$ & $0,99 \%$ & $0,92 \%$ \\
Ajustes & $0,64 \%$ & $0,63 \%$ & $0,64 \%$ & $0,64 \%$ \\
IRPF & $0,19 \%$ & $0,68 \%$ & $0,79 \%$ & $0,47 \%$ \\
CPMF & $1,47 \%$ & $3,86 \%$ & $2,74 \%$ & $2,36 \%$ \\
Custo Total & $0,02 \%$ & $0,04 \%$ & $0,04 \%$ & $0,03 \%$ \\
\hline
\end{tabular}

Fonte: Azevedo-Filho \& Andrade (2003)

Essas duas tabelas, calculadas com base nos modelos ARIMA-GARCH selecionados, possuem um caráter distinto dos resultados obtidos através do Método 1 (preços observados). Isso porque são os custos médios de uma distribuição de 
probabilidade, obtida através de um processo de simulação de 10.000 trajetórias de preços. Esse tipo de análise permite, a princípio, duas novas informações: a) a magnitude de cada custo não é calculada baseada em uma única trajetória de preços, como utilizado no Método 1; b) em se tratando de custos médios, pode-se argumentar que o custo total médio de uma transação, considerando que um contrato possui um comprador e um vendedor, é exatamente o dobro dos custos médios apresentados para um agente que vende contratos; logo, os custos médios calculados servem para ambos os casos: comprador e vendedor de contratos futuros.

Com relação à magnitude dos custos, nota-se que foram expressivos para um período de 120 dias de operação (entre $2,14 \%$ e 6,48\% do valor inicial do contrato), principalmente para agentes menos capitalizados. Outra consequiência do método de simulação é que todos os custos foram positivos, diferentemente do Método 1, em que IRPF e juros, eram influenciados pela trajetória de preços observada, podendo ter valores iguais a zero ou até mesmo negativos (recebimento de dinheiro). Isso implica que mesmo tendo a possibilidade de ganhos com taxas de juros no caso de recebimento de ajustes, em média, os custos se sobrepõem aos ganhos. Outra característica interessante é que a magnitude dos custos operacionais, em média, é muito próxima do que geralmente é considerado na literatura (Marques \& Mello, 1999), de 0,64\%.

Para melhor compreender a interação entre os custos de transação, as Tabelas 13 e 14 apresentam a correlação amostral entre eles, para os modelos estimados a partir dos vencimentos MAI03 e JAN03, para agentes tipo 2 (descapitalizados).

Tabela 13. Matriz de correlação amostral entre os componentes do custo do modelo associado ao contrato MAI03, para agentes tipo 2.

\begin{tabular}{cccccccc}
\hline & CT & MARGEM & TAXAS & AJUSTE & IRPF & CPMF & Variação \\
\hline CT & 1,00 & & & & & & \\
MARGEM & 0,00 & 1,00 & & & & & \\
TAXAS & 0,13 & 0,00 & 1,00 & & & & \\
AJUSTE & 0,39 & 0,00 & 0,85 & 1,00 & & & \\
IRPF & 0,19 & 0,00 & $-0,84$ & $-0,83$ & 1,00 & & \\
CPMF & 0,47 & 0,00 & 0,87 & 0,76 & $-0,54$ & 1,00 & \\
Variação & 0,13 & 0,00 & 1,00 & 0,84 & $-0,84$ & 0,87 & 1,00 \\
\hline
\end{tabular}

Fonte: Azevedo-Filho \& Andrade (2003) 
Tabela 14. Matriz de correlação amostral entre os componentes do custo do modelo associado ao contrato JAN03, para agentes tipo 2.

\begin{tabular}{cccccccc}
\hline & CT & MARGEM & TAXAS & AJUSTE & IRPF & CPMF & Variação \\
\hline CT & 1,00 & & & & & & \\
MARGEM & 0,00 & 1,00 & & & & & \\
TAXAS & 0,21 & 0,00 & 1,00 & & & & \\
AJUSTE & 0,49 & 0,00 & 0,85 & 1,00 & & & \\
IRPF & 0,21 & 0,00 & $-0,81$ & $-0,75$ & 1,00 & & \\
CPMF & 0,54 & 0,00 & 0,88 & 0,78 & $-0,48$ & 1,00 & \\
Variação & 0,21 & 0,00 & 1,00 & 0,85 & $-0,81$ & 0,88 & 1,00 \\
\hline
\end{tabular}

Fonte: Azevedo-Filho \& Andrade (2003)

A análise das correlações apresentadas apenas confirma a idéia de que os custos de imposto (IRPF) e ajustes possuem comportamentos opostos. Isso porque, observada certa trajetória de preços que implique no pagamento de ajustes por parte de um agente, os custos de tributação serão próximos de zero e os custos de juros para honrar compromissos com os ajustes, serão positivos. Por outro lado, essa situação se inverte quando a trajetória de preços implicar em recebimento de ajustes. Nesse caso, os custos de juros poderão até ser negativos (recebimento líquido de dinheiro advindo da aplicação dos ajustes), mas haverá um alto volume pago de imposto de renda.

\subsection{Resultados do Método 3}

Este modelo teórico baseia-se apenas no valor da volatilidade para simular as trajetórias de preços, sendo um método simples, mas que permite alguns tipos de análise que os modelos anteriores não são capazes de oferecer. Obviamente, essas vantagens vêm à custa de certas limitações, pois não são capturados aspectos relevantes da realidade como os modelos do Método 2.

Antes dos resultados acerca dos custos propriamente ditos, dado que esse modelo baseia-se na volatilidade, são apresentados na Tabela 15 seus valores estimados (o modo de obtenção da volatilidade está descrito em 4.2.5, e também é encontrado em Harwood et al., 2002) para as quatro séries de preços observadas, relativas ao mercado do milho. 
Tabela 15. Volatilidade estimada através da trajetória real dos preços futuros do milho na $\mathrm{BM} \& \mathrm{~F}$

\begin{tabular}{ccc}
\hline Série & $\begin{array}{c}\text { Volatilidade } \\
\text { diária }\end{array}$ & $\begin{array}{c}\text { Volatilidade } \\
\text { Anualizada }\end{array}$ \\
\hline MAI02 & 0,0109 & 0,1737 \\
JAN03 & 0,0172 & 0,2741 \\
MAR03 & 0,0176 & 0,2804 \\
MAI02 & 0,0135 & 0,2152 \\
\hline
\end{tabular}

Fonte: Azevedo-Filho \& Andrade (2003)

Com cada uma das volatilidades calculadas, utilizou-se do processo de obtenção dos custos (para agentes descapitalizados em operação de 120 dias) para o modelo simplificado, descrito na seção 4.2.5, que gerou a Tabela 16.

Tabela 16. Custos de transação estimados em 10.000 trajetórias de preços simuladas a partir do modelo simplificado, para agentes tipo 2 (descapitalizados).

\begin{tabular}{lcccc}
\hline \multirow{2}{*}{ Componente } & \multicolumn{3}{c}{ Custos como percentagem do valor inicial do contrato } \\
\cline { 2 - 4 } & MAI02 & JAN03 & MAR03 & MAI03 dias $)$ \\
Margem & $1,72 \%$ & $1,27 \%$ & $0,99 \%$ & $0,92 \%$ \\
Taxas & $0,64 \%$ & $0,65 \%$ & $0,63 \%$ & $0,64 \%$ \\
Ajustes & $0,20 \%$ & $0,53 \%$ & $0,52 \%$ & $0,43 \%$ \\
IRPF & $1,40 \%$ & $2,15 \%$ & $2,31 \%$ & $1,76 \%$ \\
CPMF & $0,02 \%$ & $0,03 \%$ & $0,03 \%$ & $0,03 \%$ \\
Custo Total & $3,99 \%$ & $4,65 \%$ & $4,50 \%$ & $3,77 \%$ \\
\hline
\end{tabular}

Fonte: Azevedo-Filho \& Andrade (2003)

A intenção de obter esses valores foi a de comparar os dados do modelo simplificado com os resultados obtidos pelos modelos mais complexos (ARIMA- 
GARCH), e verificar se o comportamento dos custos é semelhante. O que se nota é que os resultados da Tabela 16, quando comparados com a mesma situação (agente tipo 1 e 120 dias) calculados pelo Método 2 (Tabela 12), apresentam números subestimados.

Esse fenômeno se repete nas outras possíveis comparações (restante de combinações de tipos de agente e número de dias). Logo, nos resultados do modelo a serem apresentados a seguir, que permitem analises que os outros modelos não são capazes de fazer, os possíveis problemas relativos à simplicidade do modelo implicarão que os custos calculados serão menores que os obtidos por modelos mais próximos à realidade, e não o contrário. Portanto, as limitações do modelo simplificado resultam em custos menores que os obtidos por modelos mais complexos.

A seguir, as Figuras 1 e 2 apresentam os custos totais médios, obtidos a partir de 30.000 simulações, expressos em valores percentuais do preço inicial do contrato futuro, para os agentes tipo 1 e 2, verificando o crescimento do custo conjuntamente com a evolução dos dias de negociação.

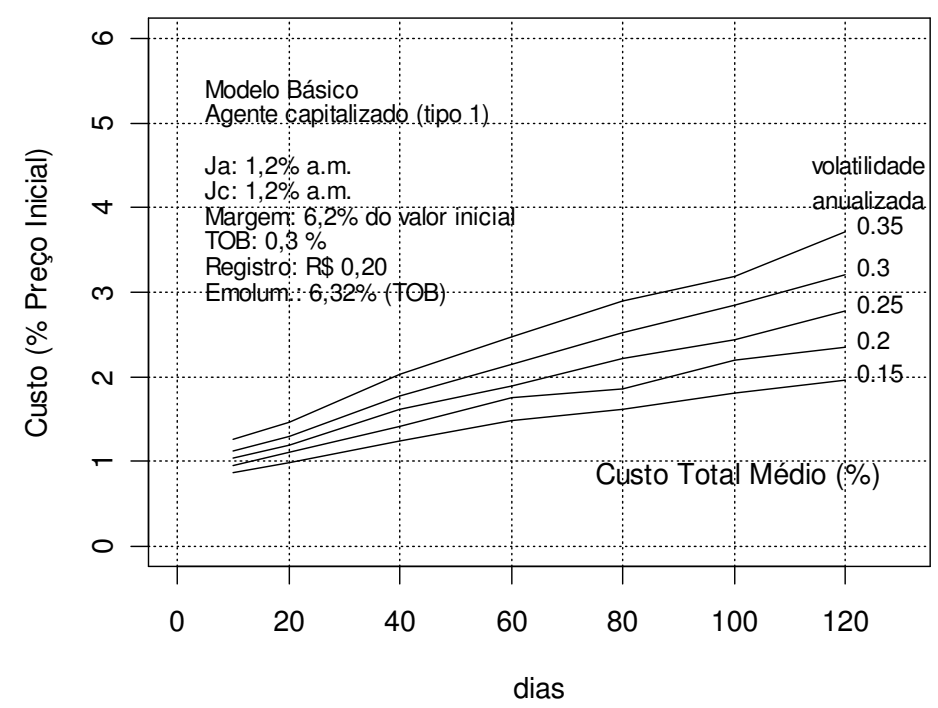

Figura 1 - Custos totais médios como \% do valor inicial do contrato, estimados a partir do modelo simplificado, para agentes tipo 1.

Fonte: Azevedo-Filho \& Andrade (2003) 


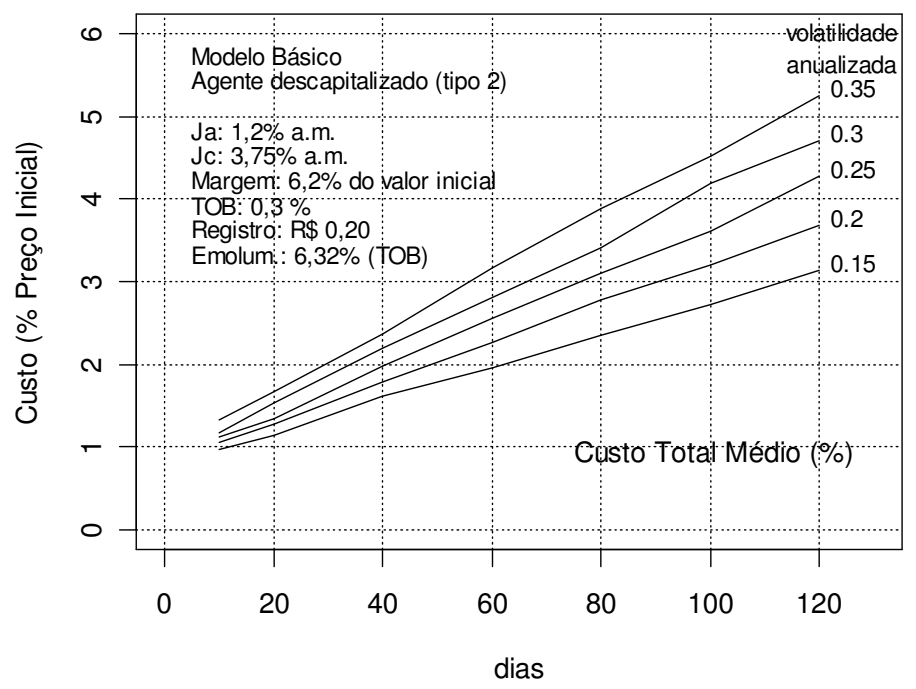

Figura 2 - Custos totais médios como \% do valor inicial do contrato, estimados a partir do modelo simplificado, para agentes tipo 2 .

Fonte: Azevedo-Filho \& Andrade (2003)

Analisando-se as figuras acima, nota-se a apresentação de características com relação ao comportamento dos custos, que os outros métodos não possibilitavam: a) os custos esperados crescem com o passar do tempo de operação; b) os custos também aumentam com maiores volatilidades. Portanto, quanto maior a incerteza (maior volatilidade ou período de tempo) os custos esperados tendem a ser mais elevados. Desse fato surge que, ao iniciar a operação, o agente depara-se com um risco de custo, dependente de diversos fatores (volatilidade dos preços, tempo de operação, seu grau de capitalização etc), que influencia diretamente na eficiência da operação.

Como forma de clarificar a idéia de risco de custo, a Figura 3 apresenta exatamente o problema da incerteza da associada ao tempo de operação (período $m$ ). 
20 dias

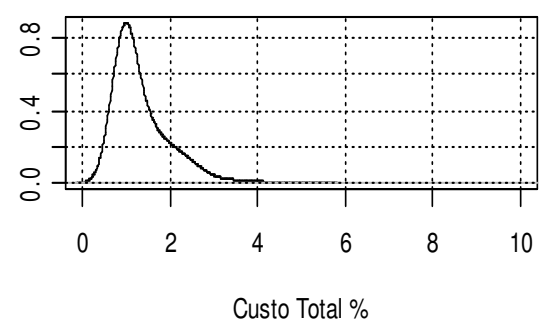

60 dias

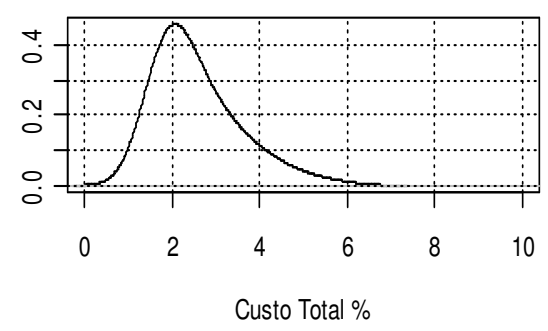

100 dias

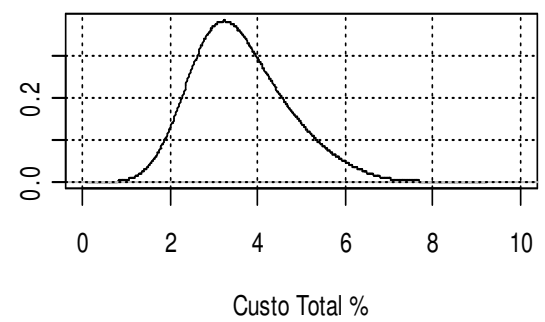

40 dias

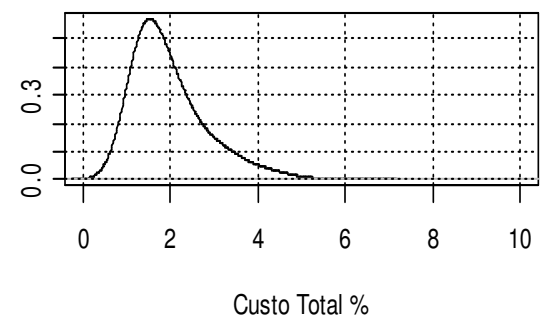

80 dias

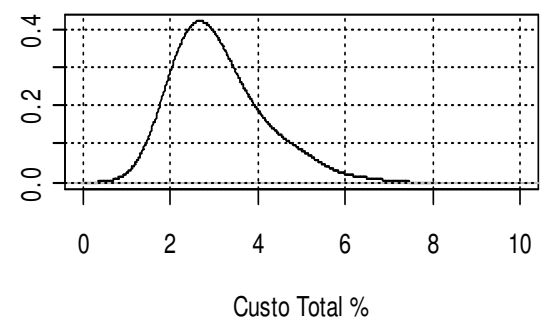

120 dias

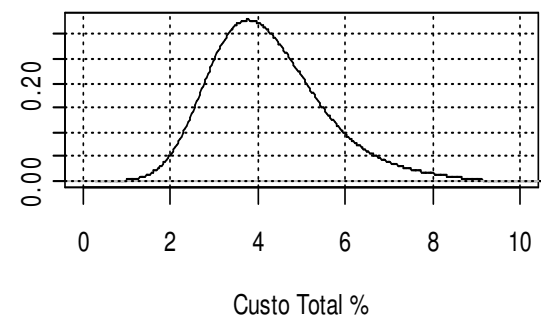

Figura 3 - Estimativas da distribuição do custo total, como \% do valor inicial do contrato, a partir do modelo simplificado, para agente tipo 2 e volatilidade anualizada de 0,25 , em função do número de dias

Fonte: Azevedo-Filho \& Andrade (2003)

O que se nota nessas distribuições é que há um alto grau de incerteza, no início do contrato, quanto aos custos que realmente serão observados ao seu final. Para 120 dias de operação, por exemplo, os custos podem variar de 2 a $8 \%$, sendo que a esperança matemática desta distribuição de probabilidade tem o mesmo significado dos custos médios apresentados nas tabelas anteriores (Tabela 16, por exemplo). O problema dos 
custos, portanto, está exatamente nessa incerteza, pois se fossem fixos ou conhecidos exatamente antes da operação, as decisões quanto a fazer ou não uma operação em mercados futuros seriam de muito mais fácil análise.

\subsection{Formas de diminuição dos custos transacionais ${ }^{36}$}

A primeira e mais óbvia conclusão é que uma diminuição na carga tributária das operações em mercados futuros poderia atenuar o custo da operação, e conseqüentemente aumentar a participação de agentes de mercado. Porém, até o presente trabalho, não se tinha uma análise plausível dos reais impactos que essa cobrança impunha aos agentes, nem mesmo havia clareza sobre a forma pela qual os diversos agentes eram tributados. Assim, os resultados desta pesquisa oferecem bases para se avançar nas discussões sobre quais medidas poderiam ser tomadas para a diminuição dessa modalidade de custo de transação.

Em se tratando de custos associados ao depósito de margem de garantia e ajustes diários, iniciativas recentes tem o intuito exatamente de colaborar para a diminuição desses custos financeiros. Por exemplo, há algum tempo os agentes do mercado de café possuem uma linha de crédito advindo do Fundo de Defesa da Economia Cafeeira (FUNCAFÉ). Esse fundo, baseado na resolução do Banco Central 2.701, financia o recolhimento da margem de garantia e ajustes diários, em até 100\% dos seus valores, sendo o agente financeiro o Banco do Brasil.

Esse mecanismo busca reduzir exatamente o custo financeiro relativo à necessidade de margem de garantia e ajustes diários. Isso implica que o produtor não necessite de um volume alto de capital próprio, atenuando o risco de fluxos de caixa que sejam tão negativos que o produtor necessite, num curto prazo, buscar financiamento a juros altos para continuar com sua posição nos mercados futuros. Tal fundo possibilita que o produtor pague seus débitos (em caso de ajustes negativos) com o dinheiro do fundo, liquidando esta dívida apenas quando receber o dinheiro da venda do produto no mercado físico.

36 Muitas das informações desta seção foram obtidas com C. Souza (consultar Anexo B) 
Desde março de 2003, a BM\&F e o Banco do Brasil criaram uma alternativa semelhante à oferecida pelo FUNCAFÉ, mas para todas as commodities negociadas em bolsa. Esse dinheiro financiaria até $50 \%$ do hedging, no limite de até cem mil reais por agente. Os recursos seriam oriundos da Poupança Ouro do Banco do Brasil, sendo depositados em um fundo de renda fixa, que ofereceria remunerações diárias, diminuindo o custo de oportunidade do dinheiro. O próprio fundo faria a separação do dinheiro necessário à margem de garantia, e a movimentação de ajustes diários quando necessários, diminuindo também os custos de administração da posição.

O objetivo desta pesquisa, porém, não é de explorar a fundo o funcionamento desses mecanismos, nem medir a sua real utilização e eficiência. $\mathrm{O}$ que se quis foi apresentar que há esforços recentes que visam minimizar os custos de transação relativos à necessidade de capital para fazer as negociações em mercados futuros. Esse problema é tão grave que, teoricamente, esse custo pode ser enorme. Isto é, em caso de ajustes negativos subseqüentes e de grande magnitude, o agente pode não conseguir crédito no mercado de capitais no montante requerido, sendo obrigado a buscar alternativas de altíssimo custo, como agiotas e utilização de cheque especial. No limite, pode não haver crédito de nenhuma fonte para atender suas necessidades de curto prazo. Isso obrigaria o encerramento da operação, o agente encontrar-se-ia descapitalizado, e a administração de risco acabaria. 


\section{CONCLUSÕES}

Este trabalho buscou caracterizar os custos de transação em mercados futuros como forma de estudar uma das possíveis razões levariam certos agentes de mercado a não utilizarem desse instrumento. Para isso, foram identificados os principais custos de transação citados na literatura, aplicados ao mercado de derivativos. Posteriormente, foram feitas entrevistas informais com especialistas e agentes de mercado para verificar a relevância desses custos, e também como forma de perceber algum outro custo peculiar ao mercado brasileiro, não citado na literatura consultada.

Dessa investigação, surgiram os dois primeiros resultados dessa pesquisa, que correspondem a duas propostas de sistematização. A primeira diz respeito aos custos de transação inerentes à operação, que podem afetar qualquer indivíduo que opere em mercados futuros: aprendizado e capacitação, taxas da bolsa e corretoras, liquidez do mercado, administração da operação, margem de garantia, ajustes diários e tributação.

A segunda sistematização diz respeito a uma classificação da forma de incidência de tributos nessas operações, conforme o tipo de agente analisado. Para pessoa física, os dois únicos tributos incidentes são a CPMF e o IRPF. No caso de pessoa jurídica incidem os tributos Pis/Pasep, Cofins, IRPJ, CSLL e CPMF, sendo que há diferenças de cobrança dependendo do regime pelo qual a pessoa jurídica é tributada: lucro real, lucro presumido ou lucro arbitrado. Apesar de os impactos dessas diferenças não terem sido medidos neste trabalho, o que se notou é que tais custos possuem peculiaridades muito marcantes e que os próprios agentes do mercado são pouco familiarizados com este tema.

Outro objetivo deste trabalho foi o de mensurar certos custos de transação para verificar sua magnitude frente ao volume negociado, sendo que independem se o indivíduo opera ou não no mercado físico da commodity em questão. O que se propôs 
foi um estudo de caso envolvendo o mercado futuro do milho no Brasil, na BM\&F, em que se mediu quatro custos de transação em particular, seguindo a sistematização anteriormente proposta: a) custos de tributação; b) custo de margem de garantia; c) custos de ajustes diários; d) custos referentes às taxas da bolsa e de corretoras.

Os cálculos foram aplicados para o caso de pessoa física, utilizando-se de três métodos distintos e complementares: a) com base em séries de preços futuros observadas; b) através de modelos sofisticados denominados ARIMA-GARCH; c) utilizando-se de um modelo simplificado dependente, basicamente, da volatilidade dos preços. Esses métodos permitiram a obtenção de valores de custos na forma percentual, com relação ao valor inicial do contrato.

Foram analisados dois tipos de agentes de mercado, com casos extremos de estrutura financeira: o primeiro seria totalmente capitalizado, e o segundo não possuiria capital próprio algum, sendo que qualquer desembolso requerido na operação, seria feito através de empréstimo de dinheiro no mercado (a certa taxa de juros). Obtidos os resultados, notou-se que certos custos (margem de garantia, ajuste e tributação) são muito mais significativos que as taxas operacionais cobradas pela bolsa e corretoras. Em operações de 120 dias, por exemplo, os custos totais médios estiveram entre 2,0 a 4,5\% (para agentes capitalizados) e entre 4,0 e 6,5\% (para agentes descapitalizados) do valor inicial do contrato, sendo que as taxas da bolsa e corretora representaram apenas 0,64\% do valor do contrato (resultados do modelo ARIMA-GARCH).

A aplicação dos três métodos propostos forneceu outras informações interessantes: a) há um risco de custo em se operar em mercados futuros, que conjuntamente ao risco de base (para agentes que negociam no mercado físico), aumenta a incerteza quanto ao resultado final da operação; b) os riscos de custo são relacionados, fortemente, com incerteza das trajetórias de preços que realmente acontecerão; c) estas trajetórias, por sua vez, dependem da volatilidade dos preços e do período de operação; c) quanto menos capitalizado o agente, quanto maior o tempo de operação, e quanto maior a volatilidade esperada, a esperança matemática dos custos tende a ser maior que nas situações contrárias. 
Outra peculiaridade é que além da magnitude dos custos para um agente ser expressiva, o que se verifica é que na operação como um todo seu valor será, em média, o dobro dos percentuais calculados. Isso porque ao considerar as duas partes envolvidas na transação (comprador e vendedor de um contrato), verifica-se que esperança matemática dos custos para as contrapartes é a mesma. Além disso, ao analisar trajetórias de preços específicas e a estrutura financeira dos agentes, nota-se que os custos podem ser assimétricos, ou seja, geralmente uma das partes (comprador ou vendedor) observa um custo maior que a outra.

A percepção de que os custos de transação em mercados futuros podem ser altos traz implicações tanto do ponto de vista acadêmico, como para o próprio mercado. Exemplos disso são: muitos trabalhos consideram os custos de transação em mercados futuros algo insignificante frente ao volume total negociado (como em Nelson, 1985 e Harwood et al., 2002); alguns livros textos tratam apenas das taxas operacionais (Hull, 1996 e Marques e Mello, 1999); Oliveira (2000) utiliza percentuais de 0,15\%, 0,20\% e $0,25 \%$, do valor total do contrato, para analisar a influência dos custos de transação no cálculo de razão de hedge para diversas commodities negociadas na BM\&F; agentes do mercado gastam tempo negociando valores das taxas cobradas pelas corretoras, mas não sabem exatamente qual foi o valor dos gastos, por exemplo, com tributos.

Esses casos mostram que há muito para se entender sobre custos de transação em mercados futuros. Espera-se que as conclusões deste trabalho ajudem não só no direcionamento de pesquisa acadêmica no estudo dos custos de transação, mas também auxiliem a própria $\mathrm{BM} \& \mathrm{~F}$ a alocar esforços para problemas realmente relevantes. Um exemplo é colocar em discussão o porquê da excessiva carga tributária em mercados futuros, que acabam por inibir a entrada de agentes, por exemplo, menos capitalizados, que podem em muitas situações ser os que mais se beneficiariam de um mecanismo de administração de risco. Logo, a busca de diminuição desses custos pode também ser uma medida eficaz para o aumento da participação dos agentes nos mercados futuros, com conseqüente elevação da liquidez do mercado.

Dessa forma, a presente pesquisa buscou trazer uma linha de estudos sobre mercados futuros, muito pouco debatida no contexto brasileiro. Temas como a relação 
entre risco de custo e risco de base, mensuração dos potenciais custos não abordados neste trabalho, estudo sobre os impactos da diferença entre a tributação de pessoa física e jurídica, devem ser temas de futuros trabalhos acadêmicos. Esses esforços poderão contribuir para um melhor entendimento dos custos e benefícios da utilização de mercados futuros no Brasil. 
ANEXOS 


\section{ANEXO A - Forma e período de pagamento de imposto para pessoas jurídicas ${ }^{37}$.}

I - Para as pessoas jurídicas que optarem pela apuração trimestral do imposto (lucro real, presumido ou arbitrado), o prazo de recolhimento será:

a) pagamento em quota única: até o último dia útil do mês subseqüente ao do encerramento do período de apuração (períodos de apuração encerrados em 31 de março, 30 de junho, 30 de setembro e 31 de dezembro);

b) à opção da pessoa jurídica, o imposto devido poderá ser pago em até três quotas mensais, iguais e sucessivas, vencíveis até o último dia útil dos três meses subseqüentes ao do encerramento do período de apuração a que corresponder. As quotas do imposto serão acrescidas de juros equivalentes à taxa do Sistema Especial de Liquidação e Custódia para títulos federais - Selic, acumulada mensalmente a partir do $1^{\mathrm{o}}$ dia do $2^{\underline{\mathrm{o}}}$ mês subseqüente ao do encerramento do período de apuração até o último dia do mês anterior ao de pagamento; e, no mês do pagamento, os juros serão de $1 \%$ sobre o valor a ser pago, sendo que a primeira quota quando paga até o vencimento não sofrerá acréscimos.

II - Para as pessoas jurídicas que optarem pela apuração mensal da base de cálculo do imposto pela estimativa e determinação do lucro real em 31 de dezembro:

a) o imposto devido mensalmente de janeiro a dezembro de cada ano calendário (com base na estimativa), deverá ser pago até o último dia útil do mês subseqüente àquele a que se referir;

b) o saldo do imposto apurado em 31 de dezembro do ano calendário, obtido do confronto entre o valor do imposto devido com base no lucro real anual e das estimativas pagas no decorrer do período:

b.1) será pago em quota única até o último dia útil do mês de março do ano subseqüente. $\mathrm{O}$ saldo do imposto será acrescido de juros equivalentes à taxa referencial do Sistema Especial de Liquidação e Custódia - Selic, para títulos federais, acumulada mensalmente, a partir de $1^{\underline{o}}$ de fevereiro até o último dia do mês anterior ao do pagamento e de $1 \%$ (um por cento) no mês do pagamento;

\footnotetext{
${ }^{37}$ Informação obtida no site da Secretaria da Receita Federal: http://www.receita.fazenda.gov.br
} 
b.2) poderá ser compensado com o imposto de renda devido a partir do mês de janeiro do ano-calendário subseqüente ao do encerramento do período de apuração, assegurada a alternativa de requerer a restituição, observando-se o seguinte (AD SRF $\mathrm{n}^{\mathrm{o}}$ $3 / 2000)$

b.2.1) os valores pagos, nos vencimentos estipulados na legislação específica, com base na receita bruta e acréscimos ou em balanço ou balancete de suspensão ou redução nos meses de janeiro a novembro, que excederem ao valor devido anualmente, serão atualizados pelos juros equivalentes à taxa referencial do Sistema Especial de Liquidação e Custódia - Selic para Títulos Federais, acumulada mensalmente, a partir de $1^{\text {o }}$ janeiro do ano-calendário subseqüente àquele que se referir o ajuste anual até o mês anterior ao da compensação e de $1 \%$ relativamente ao mês da compensação que estiver sendo efetuada;

b.2.2) o valor pago, no vencimento estipulado em legislação específica, com base na receita bruta e acréscimos ou em balanço ou balancete de suspensão ou redução relativo ao mês de dezembro, que exceder ao valor devido anualmente, será acrescido dos juros equivalentes à taxa referencial do Sistema Especial de Liquidação e Custódia Selic para Títulos Federais, acumulada mensalmente, a partir $1^{\circ}$ de fevereiro até o mês anterior ao da compensação e de $1 \%$ relativamente ao mês em que a compensação estiver sendo efetuada. 
ANEXO B - Lista dos especialistas e agentes de mercado que colaboraram com o trabalho.

- Pedro Valentim Marques (Orientador): Professor do Departamento de Economia, Administração e Sociologia da ESALQ/USP

- Adriano J. B. V. Azevedo-Filho (Co-orientador): Professor do Departamento de Economia, Administração e Sociologia da ESALQ/USP

- Clímaco Cezar de Souza: Analista de mercados agropecuários do Banco do Brasil

— Edson Costa Bignotto: Analista Financeiro da MAPS Risk Management Solutions

— Eduardo Siqueira Ribeiro: Corretora Intercap S/A

— Félix Schouchana: Diretor de mercados agrícolas da BM\&F

— João Antonio Pires de Andrade: Advogado e ex-delegado da Receita Federal

— Jorge Higashino: superintendente da área de assessoria técnica da FEBRABAN

— Léo Vainzof: Link Corretora de Mercadorias LTDA

— Marlon da Silva: Link Corretora de Mercadorias LTDA 


\section{ANEXO C - Derivação da esperança dos desvios (modelo de Osborne, 1959).}

Partindo de

$$
E\left(e^{r_{t}}\right)=E\left(e^{r_{t}} e^{-\mu} e^{\mu}\right)=-e^{\mu} E\left(e^{r_{t}-\mu}\right)
$$

e considerando que $r_{t}$ tem distribuição normal, verifica-se sua esperança pode ser definida por

$$
\begin{aligned}
& E\left(e^{r_{t}}\right)=e^{\mu} \int_{-\infty}^{\infty} e^{r-\mu} e^{-\frac{(W-\mu)^{2}}{2 \sigma^{2}}} \frac{1}{\sqrt{2 \pi} \sigma} d x \\
& =e^{\mu} \frac{1}{\sqrt{2 \pi} \sigma} \int_{-\infty}^{\infty} e^{\frac{\left[2 \sigma^{2}(r-\mu)-(r-\mu)^{2}\right]}{2 \sigma^{2}}} d x
\end{aligned}
$$

Usando-se da técnica de completar o quadrado na expressão entre colchetes, verifica-se que

$$
E\left(e^{r_{t}}\right)=e^{\mu} \frac{1}{\sqrt{2 \pi} \sigma} \int_{-\infty}^{\infty} e^{\frac{\left(\sigma^{2}+\mu-r\right)^{2}}{2 \sigma^{2}}} e^{-\frac{\sigma^{2}}{2}} d x
$$

levando-se em consideração que a integral da distribuição de média $\left(\mu+\sigma^{2}\right)$ e variância $\sigma^{2}$, multiplicada pela expressão $\frac{1}{\sqrt{2 \pi} \sigma}$, é igual a $1^{38}$, a expressão acima resume-se a

$$
E\left(e^{r_{t}}\right)=e^{\mu-\frac{\sigma^{2}}{2}}
$$

\footnotetext{
${ }^{38}$ No caso, $\frac{1}{\sqrt{2 \pi} \sigma} \int-e^{-\frac{1}{\sigma^{2}\left[W-\mu-\sigma^{2}\right]^{2}}}=1$
} 


\section{REFERÊNCIAS BIBLIOGRÁFICAS}

ANDERSEN, T.; BOLlERSLEV, T.; DIEBOLD, F.X.; LABYS, P. Modeling and forecasting realized volatility. Econometrica, v.71, n.2, p.529-626, 2003.

ANTONOVITZ, F.; PARK, T.A. Testable hypotheses of the competitive firm using hedging to manage price risk. Journal of Economics and Business, v.44, n.2, p.69$85,1992$.

AZEVEDO-FILHO, A.J.B.V. Seguros fundamentados em índices de produtividade e renda agrícola regional como instrumentos para administração de risco no Brasil. Piracicaba, out. 2001. 121p. (Projeto FAPESP/CNPq/DEAS/CEPEA. Relatório de Pesquisa - SubProjeto 8)

AZEVEDO-FILHO, A.J.B.V.; ANDRADE, E.A.P. Caracterização de trajetórias de preços, fluxos de caixa e custos operacionais em mercados futuros através de simulação Monte Carlo. Piracicaba: ESALQ, Depto. Economia, Administração e Sociologia, 2003. (Série Pesquisa, 55)

BAER, H.L.; FRANCE, V.G.; MOSER, J.T. Opportunity cost and prudentiality: an analysis of futures clearing house behavior. http://www.ace.uiuc.edu/ofor/wp0196/ ofor9601.rtf (13 Nov. 2002)

BARROS, G.S.C. Políticas agrícolas: mercados futuros e de opções. Preços Agrícolas, v.11, n.127, p.12-15, maio 1997. 
BARRY, P.J. The setting. In: BARRY, P.J. (Ed.). Risk management in agriculture. Iowa: Iowa State University Press, 1984. cap.1, p.3-10.

BIGNOTTO, E.C.; AZEVEDO-FILHO, A.J.B.V. Financial risk monitoring and transaction costs in coffee \& soybean trading companies and processors. Revista de Economia e Sociologia Rural, v.41, n.1, p.139-152, 2003.

BOLLERSLEV, T. Generalized autoregressive conditional heteroscedasticity. Journal of Econometrics, v.31, n.3, p.307-327, 1986.

BOLSA DE MERCADORIAS E FUTUROS (BM\&F). Boletim informativo. http://www.bmf.com.br/ (17 dez. 2003)

BOX, G.; JENKINS, G. Time series analisys: forecasting and control. San Francisco: Holden Day, 1976. 592p.

BRORSEN, B.W. Liquidity costs and scalping returns in the corn futures market. The Journal of Futures Markets, v.9, n.3, p.225-236, 1989.

CARVALHO, N.M. Evidenciação de derivativos. http://www.eac.fea.usp.br/cadernos/ completos/cad20/evidenciacao.pdf (20 ago. 2002)

CARVALHO, P.B. Curso de direito tributário. São Paulo: Saraiva, 2003. 548p.

COASE, R.H. The nature of the firm. Economica, v.4, n.16, p.386-405, 1937.

COLLINS, R.A. Toward a positive economic theory of hedging. American Journal of Agricultural Economics Association, v.79, n.2, p.488-499, 1997. 
COX, C.C. Futures trading and market information. Journal of Political Economy, v.84, n.6, p.1215-37, 1976.

CUNY, C.J. The role of liquidity in futures markets innovations. The Review of Financial Studies, v.6, n.1, p.57-78, 1993.

CHEUNG, S.N.S. Transaction costs, risk aversion, and the choice of contractual arrangements. The Journal of Law and Economics, v.12, n.1, p.23-42, 1969.

DEMSETZ, H. Toward a theory of property rights. American Economic Review, v.57, n.2, p.347-359, 1967.

DEMSETZ, H. The cost of transacting. Quarterly Journal of Economics, v.82, n.4, p.33-53, 1968.

DINIZ, M.H. Dicionário jurídico. São Paulo: Saraiva, 1998. 635p.

DORWARD, A. The efects of transaction costs, power and risk on contractual arrangements: a conceptual framework for quantitative analysis. Journal of Agricultural Economics, v.52, n.2, p.59-73, 2001.

DUFFIE, D. Futures markets. New Jersey: Pretice-Hall International, 1989. 415p.

EGGERSTSSON, T. Economic behavior and institutions. Cambridge: Cambridge University Press, 1990. 385p.

ENGLE, R.F. Autoregressive conditional heteroscedasticity with estimates of the variance of United Kingdom inflation. Econometrica, v.50, n.5, p.987-1008, 1982. 
ENGLE, R.F. GARCH 101: the use of ARCH/GARCH models in applied econometrics. Journal of Economic Perspectives, v.15, n.4, p.157-168, 2001.

ENNEW, C.; MORGAN, W.; RAYNER, T. Role of attitudes in the decision to use futures markets: the case of the London potatos Futures Markets. Agribusiness, v.8, n.6, p.561-573, 1992.

FAMA, E. Eficient capital markets: a review of theory and empirical work. Journal of Finance, v.25, p.383-417, 1970.

FUTURES INDUSTRY INSTITUTE. Curso de futuros e opções. São Paulo: Bolsa de Mercadorias \& Futuros / Cultura Editores Associados, 1998. 258p.

GARDNER, B.L. Recent risk management policy developments in North America and the prospects for commodity price insurance in developing countries. http:// www.worldbank.org/research/abcde/eu_2000/pdffiles/gardner.pdf (02 Mar. 2003)

GONZALEZ, B.C.R. Os ambientes contratual e operacional da cédula de produto rural (CPR) e interações com os mercados futuros e de opções. Piracicaba, 1999. 169p. Tese (Doutorado) - Escola Superior de Agricultura "Luiz de Queiroz", Universidade de São Paulo.

HAIGH, M.S.; HOLT, M.T. Hedging multiple price uncertainty in international grain trade. American Journal of Agricultural Economics, v.82, n.4, p.881-896, 2000.

HARTZMARK, M.L. The effects of changing margin levels of futures market activity, the composition of traders in the market, and price performance. Journal of Business, v.59, n.2, p.147-180, 1986. 
HARWOOD, J.; HEIFNER, R.; COBLE, K.; PERRY, J.; SOMWARU, A. Managing risk in farming: concepts, research, and analysis. www.ers.usda.gov/publications/ era/aer774.pdf (25 Oct. 2002)

HIERONYMUS, T.A. Economics of futures trading. New York: Commodity Research Bureau, 1977. 369p.

HIRSHLEIFER, D. Risk, futures pricing, and the organization of production in commodity markets. Journal of Political Economy, v.96, n.6, p.1206-20, 1988.

HOBBS, J.E. Measuring the importance of transaction costs in cattle marketing. American Journal of Agricultural Economics, v.79, n.4, p.1083-1095, 1997.

HOUTHAKKER, H.S. The scope and limits of futures trading. In: ABRAMOVITZ, M. et al. The allocation of economic resource. Stanford: Stanford University Press, 1959. p.134-159.

HOWARD, C.T.; D'ANTONIO, L.J. The cost of hedging and the optimal hedge ratio. The Journal of Futures Markets, v.14, n.2, p.237-258, 1994.

HUANG, C.; LITZENBERGER, R.H. Fundations for financial economics. New York: North Holland, 1988. 359p.

HULL, J. Introdução aos mercados futuros e de opções. São Paulo: Bolsa de Mercadorias \& Futuros / Cultura Editores Associados, 1996. 447p.

INGERSOLL, J.E. Theory of financial decision making. New Jersey: Rowman \& Littlefield, 1987. 474p. 
KLEIN, B. Transaction cost determinant of "unfair" contractual arrangements. The American Economic Review, v.70, n.2, p.356-362, 1980.

LATORRACA, N. Legislação tributária. São Paulo: Atlas, 1981. 285p.

LENCE, S.H. The economic value of minimum-variance hedges. American Journal of Agricultural Economics, v.77, n.3, p.353-364, May 1995.

LEUTHOLD, R.M.; JUNKUS, J.C.; CORDIER, J.E. The theroy and practice of futures markets. Massachusetts: Lexington Books, 1989. 410p.

LIMA, L.A.O. Auge e declínio da hipótese dos mercados eficientes. Revista de Economia Política, v.23, n.4, p.28-42, 2003.

MARQUES, P.V.; SOUSA, E.L.L. Competitividade do milho e soja nos Estados Unidos e Brasil. Preços Agrícolas, v.11, n.133, p.13-18, 1997.

MARQUES, P.V.; MELLO P.C. Mercados futuros de commodities agropecuárias: exemplos e aplicações para os mercados brasileiros. São Paulo: Bolsa de Mercadorias \& Futuros, 1999. 207p.

MATTOS, F.L. Uso de contratos agropecuários em carteiras de investimento: uma análise de viabilidade. Piracicaba, 2000. 104p. Dissertação (Mestrado) - Escola Superior de Agricultura “Luiz de Queiroz”, Universidade de São Paulo.

MELO, J.E.S. Curso de direito tributário. São Paulo: Dialética, 1997. 303p.

MILGROM, P.; ROBERTS, J. Economics, organization and manegement. London: Prentice Hall International, 1992. 621p. 
MOOD, A.; GRAYBILL, F.A.; BOES, D. Introduction to the theory of statistics. New York: McGraw-Hill, 1974. 367p.

MULHERIN, J.H.; NETTER, J.M.; OVERDAHL, J.A. Prices are property: the organization of financial exchanges from a transaction cost perspective. Journal of Law \& Economics, v.34, n.2, p.591-644, 1991.

MYERS, R.J.; THOMPSON, S.R. Generalized optimal hadge ratio estimation. American Journal of Agricultural Economics, v.71, n.4, p.858-868, 1989.

NELSON, R.D. Forward and futures contracts as preharvest commodity marketing instruments. American Journal of Agricultural Economics, v.67, n.1, p.15-23, 1985 .

OLIVEIRA, A.F. Modelos para estimar razão de hedge de variância mínima: aplicação para contratos futuros agropecuários. Piracicaba, 2000. 85p. Dissertação (Mestrado) - Escola Superior de Agricultura "Luiz de Queiroz”, Universidade de São Paulo.

OSBORNE, M.M. Brownian motion in the stock market. Operations Research, v.7, p.145-173, 1959.

PEROBELLI, F.S. Análise sobre eficiência em mercados futuros: uma comparação entre os contratos de algodão em pluma da BM\&F e NYBOT. Piracicaba, 2001. 76p. Dissertação (Mestrado) - Escola Superior de Agricultura "Luiz de Queiroz", Universidade de São Paulo.

PEROBELLI, F.S. As commodities no ano de 2001. Resenha BM\&F, n.147, p.49-55, 2001. 
ROBINSON, L.J.; BARRY, P.J.; KLIEBENSTEIN, J.B.; PATRICK, G.F. Risk attitudes: concepts and measurement approaches. In: BARRY, P.J. Risk management in agriculture. Iowa: Iowa State University Press, 1984. p.3-10.

ROCHELLE, T.C.P. Relações de preço no mercado de algodão em pluma e desenvolvimento do mercado futuro de algodão no Brasil. Piracicaba, 2000. 163p. Tese (Doutorado) - Escola Superior de Agricultura "Luiz de Queiroz”, Universidade de São Paulo.

ROSA JUNIOR, L.E.F. Manual de direito financeiro \& direito tributário. Rio de Janeiro: Editora Renovar, 1995. 731p.

ROSS, S.A. Administração de empresas. São Paulo: Atlas, 1995. 698p.

SECRETARIA DA RECEITA FEDERAL (SRF). Tributação. http://www.receita.fazenda.gov.br.htm (17 dez. 2003)

SHELANSKI, H.A.; KLEIN, P.G. Empirical research in transaction cost economics. http://www.terry.uga.edu/ pklein/papers/95001.html (10 July 2002)

SIMON, H. The sciences of the artificial. Cambridge: MIT Press, 1996. 123p.

SONKA, S.T.; PATRICK, G.F. Risk management and decision making. in agricultural firms. In: BARRY, P.J. Risk management in agriculture. Iowa: Iowa State University Press, 1984. p.95-115.

SOUSA, E.L.L. Estudo do potencial de desenvolvimento de um mercado futuro de Milho no Brasil. Piracicaba, 1996. 122p. Dissertação (M.S.) - Escola Superior de Agricultura "Luiz de Queiroz", Universidade de São Paulo. 
SCHWARZ, G. Estimating the dimension of a model. Annals of Statistics, v.6, n.2, p.461-464, 1978.

TELSER, L.G. Margin and futures contracts. The Journal of Futures Markets, v.1, n.2, p.225-253, 1981.

TELSER, L.G.; HIGINBOTHAM, H.N. Organized futures markets: costs and benefits. Journal of Political Economy, v.85, n.51, p.969-1000, 1997.

THOMPSON, S.R.; WALLER, M.L. The execution cost of trading in commodity futures markets. Food Research Institute Studies, v.20, n.2, p.141-163, 1987.

THOMPSON, S.R.; WALLER, M.L. Determinants of liquidity in commodity futures markets. The Review of Futures Markets, v.7, n.1, p.110-126, 1988.

THOMPSON, S.; SONKA, S.T. Potential effects of information technologies on the economic performance of agricultural and food markets. American Journal of Agricultural Economics, v.79, n.3, p.657-662, 1997.

WILLIAMS, J. The economic function of futures markets. Cambridge: Cambridge University Press, 1986. 260p.

WILLIAMS, J. Futures markets: a consequence of risk aversion or transactions costs? Journal of Political Economy, v.95, n.51, p.1000-1023, 1987.

WILLIAMSON, O.E. Markets and hierarchies: analysis and antitrust implications. New York: the free press, 1975. 286p. 
WILLIAMSON, O.E. The economic institutions of capitalism. New York: Macmillan, 1985. 450p.

WORKING, H.G. Futures trading and hedging. American Economic Review, v.43, n.3, p.314-343, 1953. 